Energy Division

\title{
A Study of Changes in Foundation Insulation Levels in the United States
}

\author{
Jeffrey E. Christian \\ Oak Ridge National Laboratory \\ Oak Ridge, Tennessee 37831 \\ Melissa K. Voss \\ St. Mary's College \\ Winona, Minnesota
}

October 1992

Prepared by the

OAK RIDGE NATIONAL LABORATORY

Oak Ridge, Tenressee 37831

managed by

MARTIN MARIETTA ENERGY SYSTEMS, INC.

for the

U.S. DEPARTMENT OF ENERTY

under Contract No. DE-AC05-84OR21400 


\section{CONTENTS}

LIST OF FIGURES $\ldots \ldots \ldots \ldots \ldots \ldots \ldots \ldots \ldots \ldots \ldots \ldots \ldots$

LIST OF TABLES $\ldots \ldots \ldots \ldots \ldots \ldots \ldots \ldots \ldots \ldots \ldots \ldots \ldots \ldots \ldots \ldots \ldots$ vii

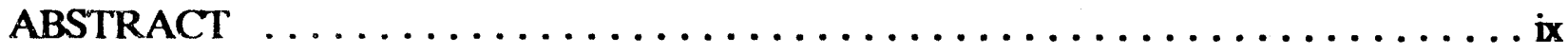

EXECUTIVE SUMMARY $\ldots \ldots \ldots \ldots \ldots \ldots \ldots \ldots \ldots \ldots \ldots \ldots \ldots \ldots \ldots$

1. INTRODUCTION $\ldots \ldots \ldots \ldots \ldots \ldots \ldots \ldots \ldots \ldots \ldots \ldots \ldots \ldots \ldots \ldots \ldots$ I

2. PROJECT DESCRIPTION $\ldots \ldots \ldots \ldots \ldots \ldots \ldots \ldots \ldots \ldots \ldots \ldots \ldots \ldots \ldots \ldots \ldots \ldots \ldots$

3. DISCUSSION OF COMPOSITE RESULTS $\ldots \ldots \ldots \ldots \ldots \ldots \ldots \ldots$

3.1 RESPONDENTS $\ldots \ldots \ldots \ldots \ldots \ldots \ldots \ldots \ldots \ldots \ldots \ldots \ldots$

3.2 INSULATION APPLICATIONS: YESTERDAY AND TODAY $\ldots \ldots \ldots 5$

3.2.1 Basement Insulation . . . . . . . . . . . . .

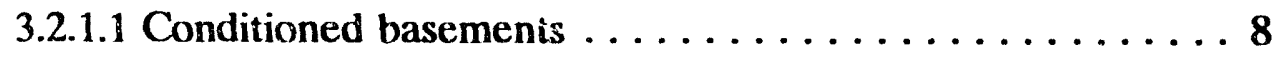

3.2.1.2 Unconditioned basements . . . . . . . . . . . . 8 8

3.2.2 Crawl Space . . . . . . . . . . . . . . . . . . . 11

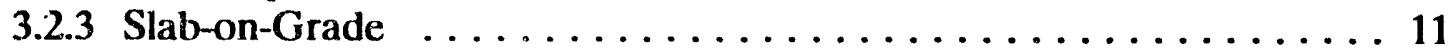

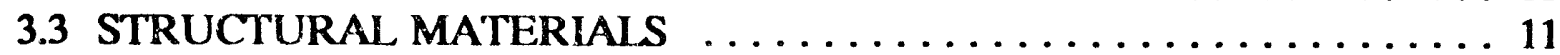

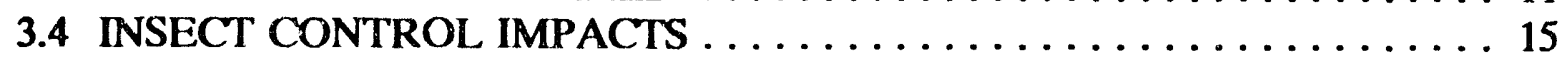

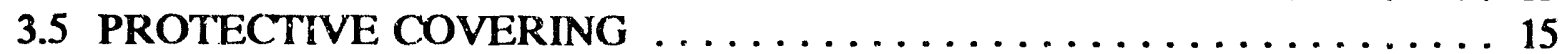

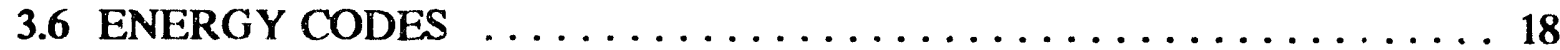

3.7 HOW MUCH INSULATION? $\ldots \ldots \ldots \ldots \ldots \ldots \ldots \ldots \ldots \ldots$

3.8 WHAT MOTIVATES FOUNDATION INSULATION DECISIONS? $\ldots 20$

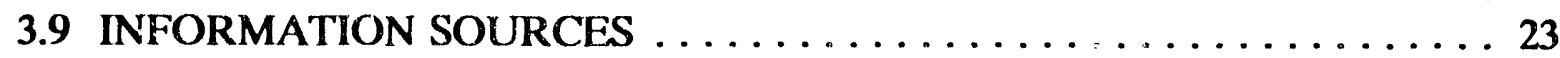

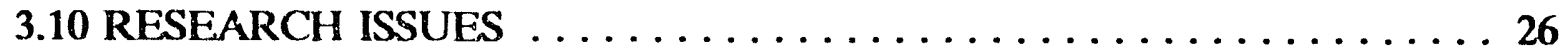

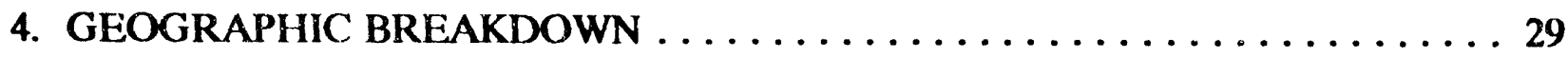

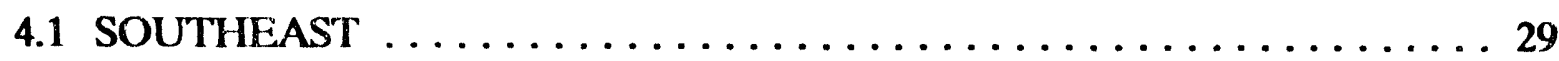

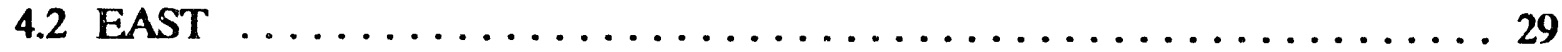

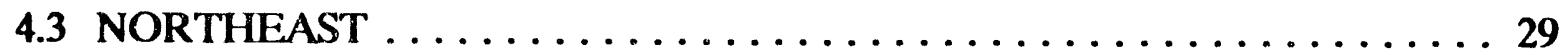

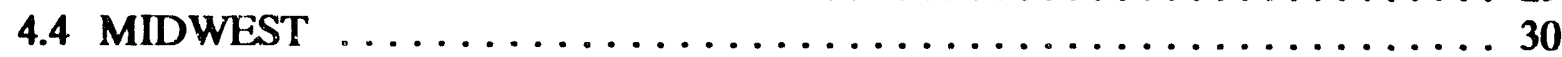

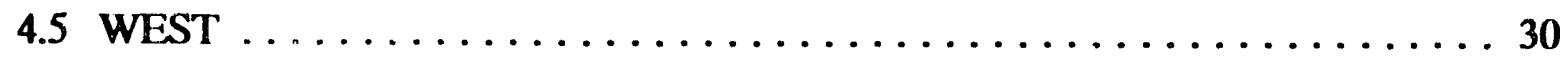

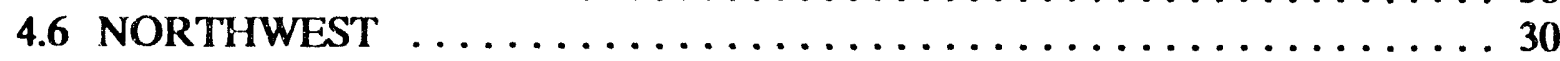

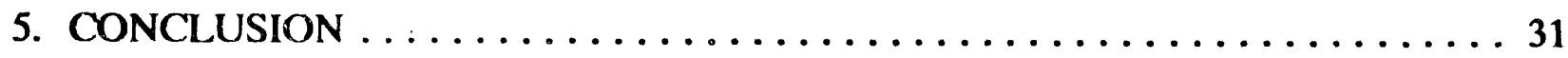

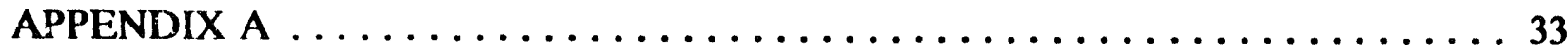

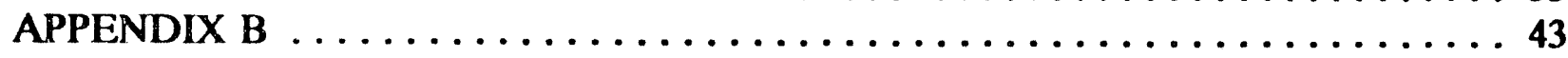




\section{LIST OF FIGURES}

Figure

Page

1 Map of U.S. showing geographic regional responses analyzed $\ldots \ldots \ldots \ldots \ldots 6$

2 Breakdown of the respondees $\ldots \ldots \ldots \ldots \ldots \ldots \ldots \ldots \ldots \ldots \ldots$

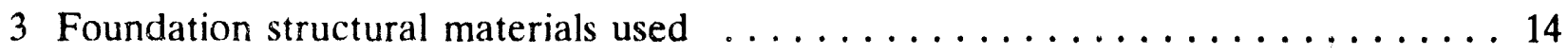

4 Does insect control impact foundation insulation? ............... 16

5 What is used to protect exterior foundation insulation

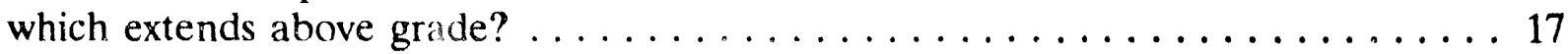

6 Is foundation insulation enforced by local codes? $\ldots \ldots \ldots \ldots \ldots \ldots \ldots$

7 How much foundation insulation is required by local codes? . . . . . . . 21

8 What has caused foundation insulation practices from 1982 to 1992 ? . . . . . . . . . . . . . . . . . . . . . . . . . . . 22

9 What information source do you use when deciding on foundation insulation?

10 Why has there been no change in foundation insulation

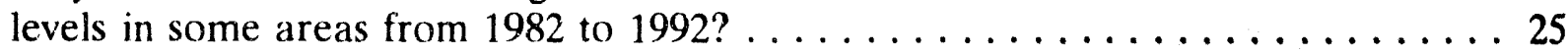

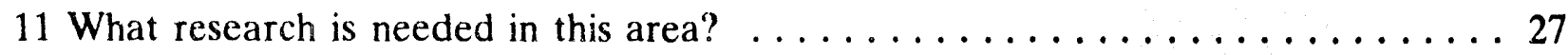

B-1 Southeast response to questions 1 and $3-9 \ldots \ldots \ldots \ldots \ldots \ldots \ldots \ldots$

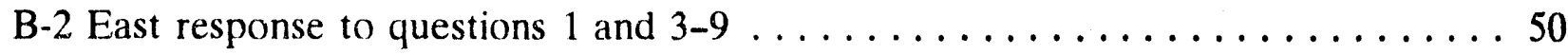

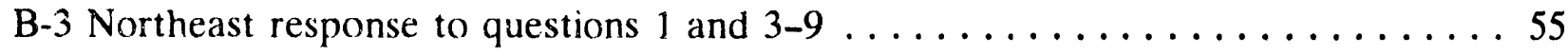

B-4 Midwest response to questions 1 and $3-9 \ldots \ldots \ldots \ldots \ldots \ldots \ldots \ldots \ldots \ldots \ldots$

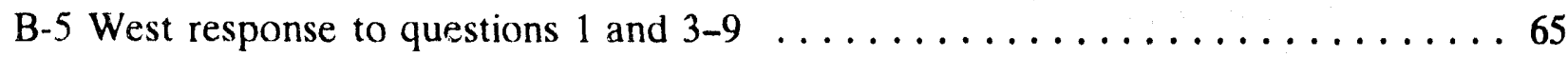

B-6 Northwest response to questions 1 and $3-9 \ldots \ldots \ldots \ldots \ldots \ldots \ldots \ldots$

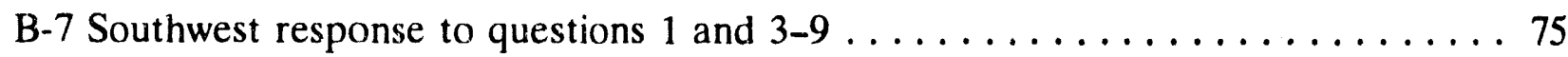




\section{LIST OF TABLES}

Table

Page

1 How are you or others in your area insulating - Conditioned

Deep Basements?

2 How are you or others in your area insulating - Unconditioned

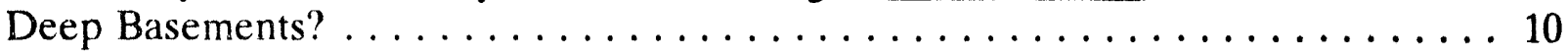

3 How are you or others in your area insulating - Crawl Spaces? $\ldots \ldots \ldots \ldots 12$

4 How are you or others in your area insulating - Slab-on-Grade

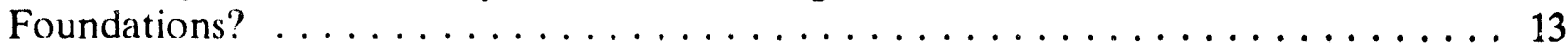

A.1 How are you insulating - Conditioned Deep Basements? . . . . . . . . 38

A.2 How are you insulating - Unconditioned Deep Basements? . . . . . . . . 39

A.3 How are you insulating - Crawl Spaces? . . . . . . . . . . . . 40

A.4 How are you or others in your area insulating - Slab-on-Grade

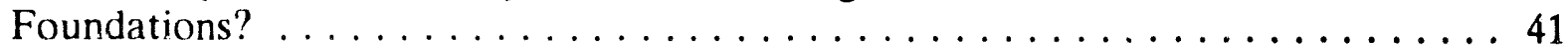

B.1 How conditioned deep basements are insulated in Southeast $\ldots \ldots \ldots \ldots 46$

B.2 How unconditioned deep basements are insulated in Southeast $\ldots \ldots \ldots \ldots 47$

B.3 How crawl spaces are insulated in Southeast $\ldots \ldots \ldots \ldots \ldots \ldots \ldots$

B.4 How slab-on-grade foundations are insulated in Southeast $\ldots \ldots \ldots \ldots \ldots 49$

B.5 How conditioned deep basements are insulated in East $\ldots \ldots \ldots \ldots \ldots \ldots$

B.6 How unconditioned deep basements are insulated in East $\ldots \ldots \ldots \ldots \ldots 52$

B.7 How crawl spaces are insulated in East $\ldots \ldots \ldots \ldots \ldots \ldots \ldots \ldots \ldots \ldots \ldots \ldots \ldots \ldots$

B.8 How slab-on-grade foundations are insulated in East $\ldots \ldots \ldots \ldots \ldots \ldots$

B.9 How conditioned deep basements are insulated in Northeast $\ldots \ldots \ldots \ldots 6$ 


\section{LIST OF TABLES (continued)}

Tabie

Page

B.10 How unconditioned deep basements are insulated in Northeast $\ldots \ldots \ldots . \ldots 57$

B.11 How crawl spaces are insulated in Northeast $\ldots \ldots \ldots \ldots \ldots \ldots \ldots$

B.12 How slab-on-grade foundations are insulated in Northeast $\ldots \ldots \ldots \ldots \ldots 59$

B.13 How conditioned deep basements are insulated in Midwest $\ldots \ldots \ldots \ldots 61$

B.14 How unconditioned deep basements are insulated in Midwest $\ldots \ldots \ldots \ldots 62$

B.15 How crawl spaces are insulated in Midwest $\ldots \ldots \ldots \ldots \ldots \ldots \ldots \ldots \ldots$

B.16 How slab-on-grade foundations are insulated in Midwest $\ldots \ldots \ldots \ldots \ldots 6$

B.17 How conditioned deep basements are insulated in West $\ldots \ldots \ldots \ldots 66$

B.18 How unconditioned deep basements are insulated in West $\ldots \ldots \ldots \ldots 7$

B.19 How crawl spaces are insulated in West $\ldots \ldots \ldots \ldots \ldots \ldots \ldots \ldots$

B.20 How slab-on-grade foundations are insulated in West $\ldots \ldots \ldots \ldots . \ldots 69$

B.21 How conditioned deep basements are insulated in North'vest $\ldots \ldots \ldots \ldots 71$

B.22 How unconditioned deep basements are insulated in Northwest $\ldots \ldots \ldots \ldots 72$

B.23 How crawl spaces are insulated in Northwest $\ldots \ldots \ldots \ldots \ldots \ldots \ldots$

B.24 How slab-on-grade foundations are insulated in Northwe:st $\ldots \ldots \ldots \ldots \ldots 74$ 


\begin{abstract}
For almost 10 years the U.S. Department of Energy (DOE) has sponsored a small research effort with the objective of working with the building industry to see that costeffective foundation insulation levels are installed in all U.S. buildings. One of the first discoveries in 1983-84 was that less than 5\% of the existing buildings had foundation insulation and less than $30 \%$ of new construction included foundation insulation. After producing foundation handbooks, actively working with energy code and standards groups (ASHRAE and Council of American Building Officials: Model Energy Code Committee), conducting field experiments, and developing computer models for predicting energy savings has any measurable progress been made toward the fulfillment of this DOE objective? Also, in order to derive maximum energy savings impact for this ongoing research activity, market feedback of progress toward attainment of the objective is needed. Using the network of building experts available to the Building Thermal Envelope Systems and Materials program, a short mail survey was developed, administered, and results analyzed. This study concludes that foundation insulation usage on new residential buildings has increased from 1982 levels of around $25 \%$ to 1992 levels of around $50 \%$. Government handbooks and recent changes in local enforced codes and standards are identified as major contributors to this improvement. Progress has been made but more is needed to capture the remaining $40 \%$ of the foundations that should be insulated. Several issues are reported as obstacles that need to be overcome to capture the remainder of the foundation market.
\end{abstract}




\section{EXECIJTIVE SUMMARY}

\section{Background}

In the early 1980s residential foundation efficiency lagged behind above-grade envelope construction practices. The U.S. Department of Energy (DOE) recognized this discrepancy and developed a research program aimed at accelerating huilding industry acceptance of energy-efficient foundations. This study attempts to determine how much more foundation insulation is used in the early 1990s compared to the early 1980s. This study also provides needed market feedback on progress toward the attainment of an important DOE research goal. This information could be used to sharpen the focus of future building foundation research.

\section{Objective}

The two objectives of this report are (1) to obtain an estimate of the progress made toward the DOE building foundation research project goal of working with the building industry to see that cost-effective foundation insulation levels are installed in residential U.S. buildings, and (2) to sharpen the focus of future research in this area.

\section{Approach}

The approach taken was to develop and adminisier a mail survey. The network cf corresponding building experts available to the Building Thermal Envelope Systems and Materials Program provided representation of all major U.S. geographic regions. This report presents the results for all 43 individuals who responded to this survey in six major U.S. regions. 


\section{Results}

In 1982 , only $26 \%$ of the conditioned basements built were insulated, compared with $54 \%$ in 1992 . In 1982, only $15 \%$ of respondees reported enforced building codes were in place requiring foundation insulation, but in 1992, 56\% reported the presence of an enforced code. Of those basement walls insulated, about half were insulated on the interior basement wall surface; the other half on the exterior. A total of $67 \%$ of builders in the Southeast and Northeast indicated that insect control impacted foundation insulation decisions, but this was not an issue ir. the Midwest or Northwest. When asked what motivated the application of foundation insulation, the two major motivators mentioned were: to be energy efficient $(36 \%)$ and to meet energy codes (32\%). Government handbooks (42\%) were cited as the number one major source for foundation insulation decisions. The foundation (43\%) and moisture control (39\%) handbooks were the most frequently cited specific references.

\section{Conclusions}

This study concludes that foundation insulation usage on new residential buildings increased from 1982 levels of around 25\% to 1992 levels of atound 50\%. Government handbocks and recent changes in local enforced codes and standards were identified as major contributors to this improvement. Progress has been made but more is needed to capture the remaining $40 \%$ of the foundations that should be insulated. Several issues are reported as obstacles that need to be overcome to capture the remainder of the foundation market.

In the mid 1980s, a major reason most builders were not insulating foundations was a "lack of information and clear guidance." The development of the foundation handbooks and incorporation of research results into national and state codes changed this. These survey results suggest that a lack of information is no longer the major problem. A more 
dedicated focus to practical cost-effective technology development and demonstration could make a difference in capturing the remaining $40-50 \%$ of foundations that should be insulated. 


\section{INTRODUCTION}

In the early 1980s, few building energy codes were required and even fewer jurisdictions enforced building foundation insulation. Were foundations better insulated in 1992 than in the early 1980s? What kept every new building foundation from having costeffective levels of insulation? These are just a few of the questions that require insight in order to evaluate the effect of past U.S. Department of Energy (DOE) foundation research and better determine future needs. The major objective of the DOE Building Foundations Research has been to lead building contractors to cost-effective, energy-efficient building foundations on all U.S. building stock.

This study attempts to identify the particular tools and methods currently used by builders, consultants, and architects in different regions of the United States to develop foundation designs. The study makes a comparison of the difference in insulation methods and levels used in 1982 compared with those used in 1992. The survey attempts to solicit those impediments that are preventing energy-efficient foundations from attaining universal acceptance across all regions of the U.S. where foundation efficiency is a good investment. 


\section{PROJECT DESCRIPTION}

One objective of this marketing research project was to determine the impact of DOE foundations research over the last ten years. This included the effect of government handbooks, ASHRAE 90.2P, and Model Energy Code (MEC) changes of October 1988. We approached the project by collecting available data, selecting a target audience, developing and administering a mail survey, and analyzing the results. We wanted a representative target audience that would be illustrative of the entire United States. We chose the recipients of the survey because they had previous correspondence with the Building Thermal Envelope Systems and Materials Program. We sent the survey to each recipient, along with an informational letter, and a no-postage-required return envelope.

We sent the survey to people of many different professions, and asked each person to identify himself or herself. Each recipient of the survey was asked to provide information on foundation insulation representative of buildirgs in their geographic area. The survey was designed to produce comparative data for analysis. The majority of the questions requested information be given for both 1982 and 1992 so that data could be compared and differences in insulation practices distinguished between the past and the present. Appendix A shows the foundation insulation survey form we distributed. 


\section{DISCUSSION OF COMPOSITE RESULTS}

\subsection{RESPONDENTS}

We sent the survey to 400 individuals on the ORNL Building Thermal Envelope Systems and Materials Program mailing list, and 43 individuals responded. In general, this group represents building experts consisting of lead builders, building material suppliers, and researchers. There was an even distribution of respondents from each of the seven regions of the United States with the exception of the Southwest, which had only one respondent. Figure 1 shows the regions used to evaluate different parts of the U.S., and Fig. 2 shows the percentages of major disciplines that responded to this surey. The occupations of the respondents varied; most respondents were engineers, and the least were builders. This was not a statistically balanced sample. We weighted the responses equally, but this could introduce errors because an answer from a respondent from an area with a great deal of new construction was weighted the same as one from an area with very little new construction.

\subsection{INSULATION APPLICATIONS: YESTERDAY AND TODAY}

Question 2 dealt with the type, quantity, and location of insulation applied to different types of foundations. From 1982 to 1992 there was a $28 \%$ increase in various insulation techniques for conditioned deep basements. For unconditioned deep basements there was a $24 \%$ increase in insulation applications from 1982 to 1992 . There was a $25 \%$ increase in insulation applications in crawl spaces, and a $43 \%$ increase in insulation application in slabon-grade foundations. The following analysis is representative of all of the respondents. Section 4 discusses the regional data. 


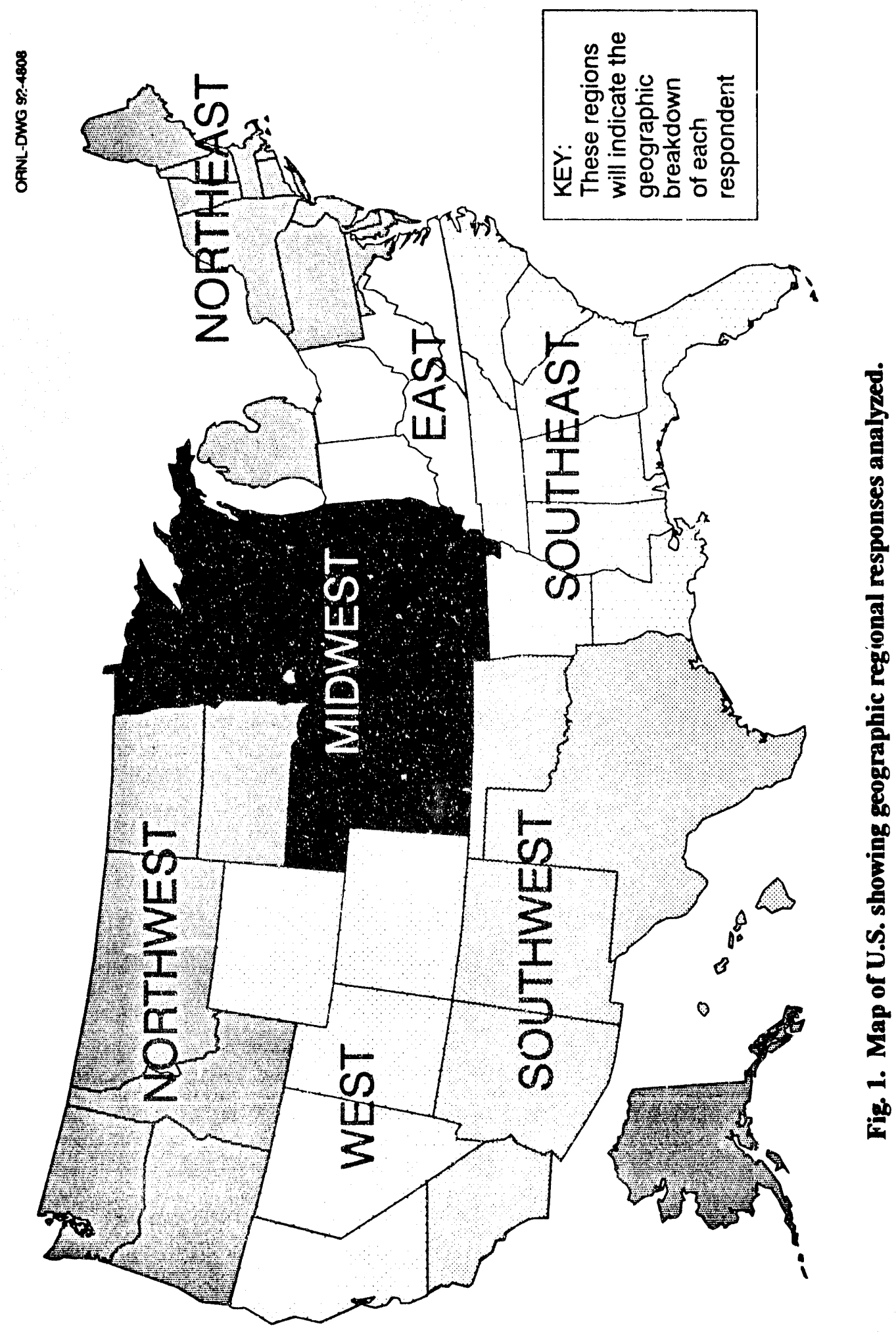



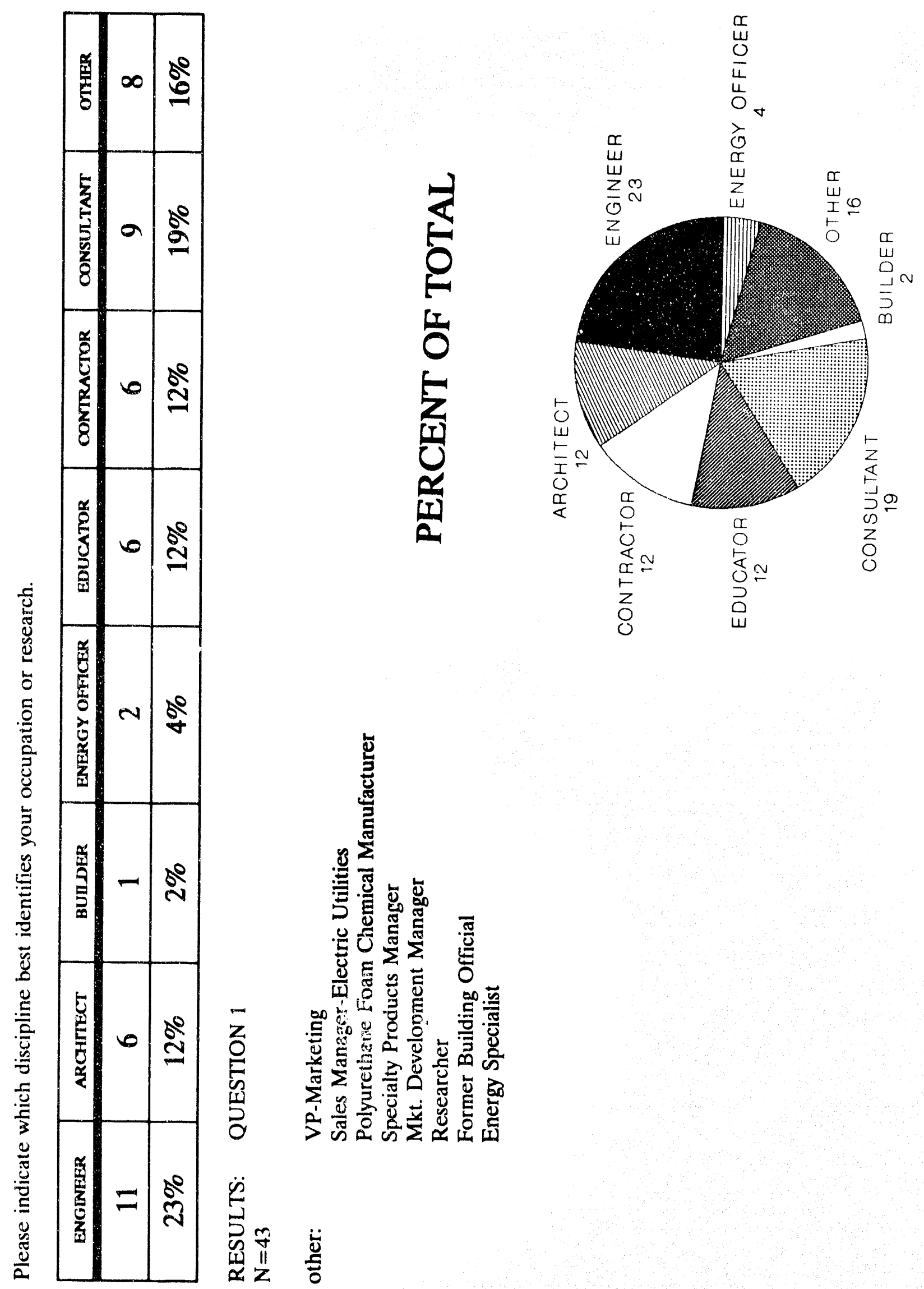

s
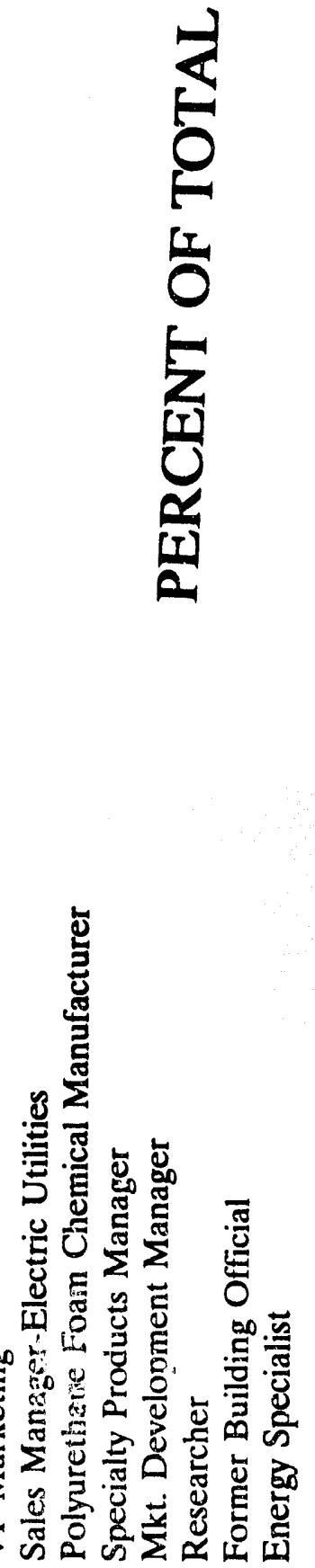

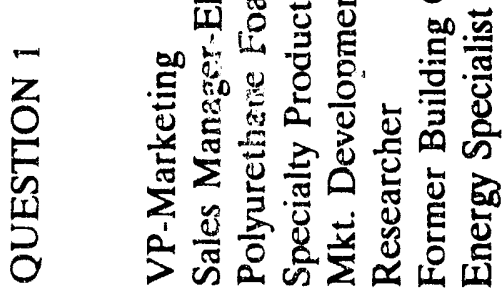

岂 


\subsubsection{Basement Insulation}

\subsubsection{Conditioned basements}

Table 1 shows the total composite average of the 31 respondents to this question. In 1982 , only $26 \%$ of the conditioned basements built were insulated, compared with $54 \%$ in 1992. In 1992, of the basements that were insulated, about half were insulated on the exterior of the basement wall, the other half on the interior surface. Of those walls insulated on the exterior, $40 \%$ were insulated only on the top portion and $60 \%$ were insulated uniformly across the entire wall.

Although the percent of basement walls constructed with pressure treated wood in 1992 was under $10 \%$, the data indicate that about $25 \%$ were left uninsulated, $25 \%$ were insulated to R-11, $25 \%$ were insulated to R-19, and $25 \%$ were insulated to R-30.

\subsubsection{Unconditioned basements}

Table 2 shows the total composite response to the question asking how unconditioned basement walls are insulated in their area. In 1982, only $12 \%$ of unconditioned basements were insulated, compared with $38 \%$ in 1992 . Of those unconditioned basement walls that were insulated, the percentage breakdown between interior and exterior was about the same as that reported for conditioned basements.

In $1982,41 \%$ of floors had no insulation separating the unconditioned basement space, compared with $32 \%$ in 1992 . We are not sure if this means that there is no insulation in the walls or the basement ceiling of these basements, because some of those $32 \%$ may have insulation in the basement walls. 
TABLE 1. How are you or others in your area insulating - Conditioned Deep Basements? (Percent of total)*

\begin{tabular}{|c|c|c|c|c|c|c|c|}
\hline \multirow[b]{2}{*}{ Configuration } & \multirow[b]{2}{*}{ Description } & \multicolumn{3}{|c|}{1982} & \multicolumn{3}{|c|}{1992} \\
\hline & & 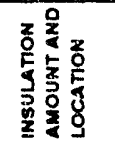 & 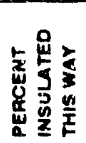 & 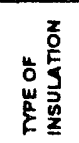 & 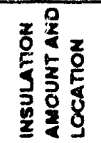 & 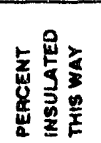 & 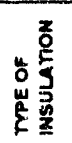 \\
\hline
\end{tabular}

A. Concrete or nuasonry foundation walls with exterior or interior insulation

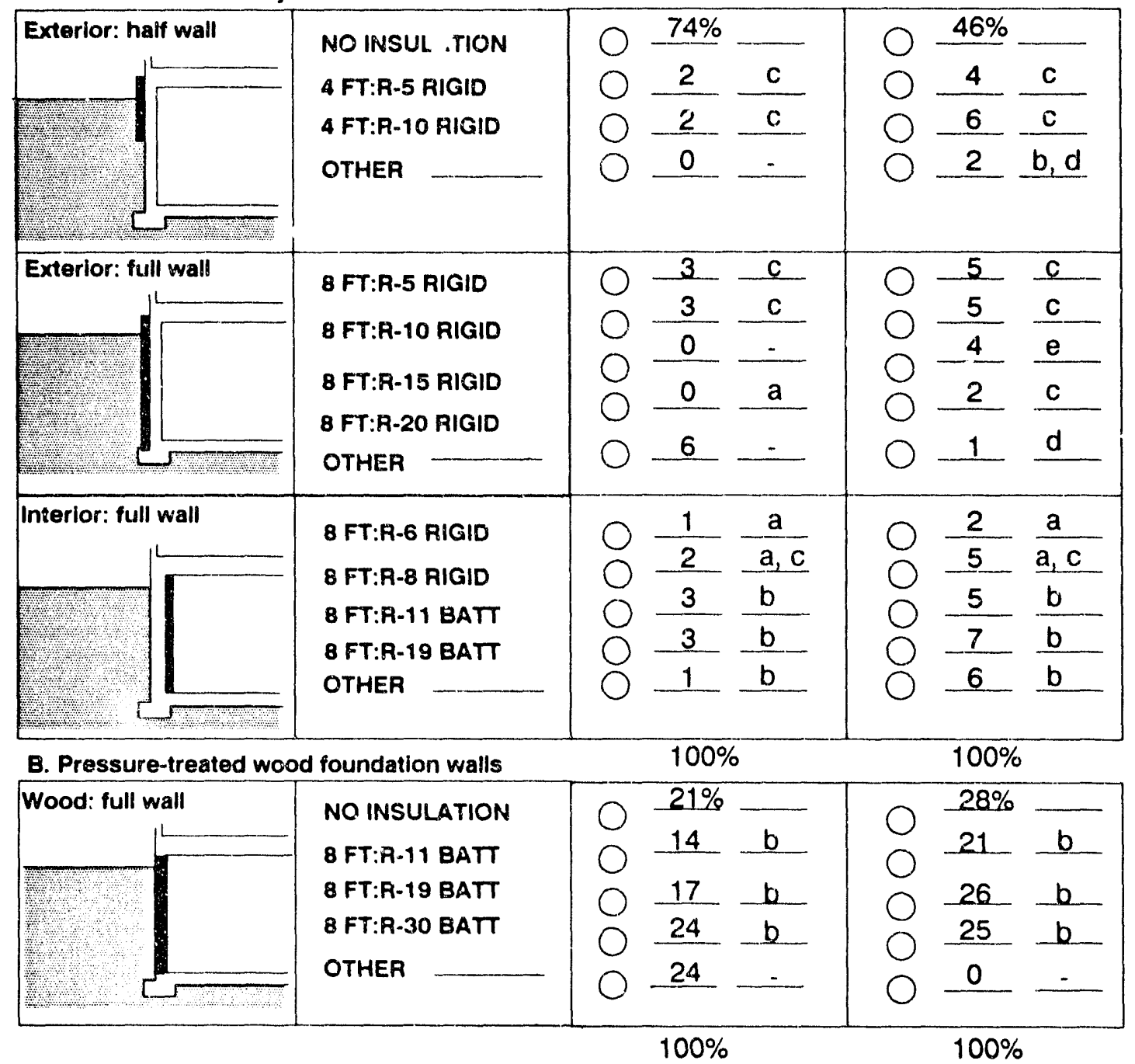

*Results: Question 2

$\mathrm{N}=31$

Note: Each percentage represents the average percentage of buildings indicated as insulated this way by the total respondents. Each letter represents the type of insulation most frequently indicated as used by the respondents. A dash represents no available data. 
Table 2. How are you or others in your area insulating - Unconditioned Deep Basements? (Percent of Total)*

\begin{tabular}{|c|c|c|c|c|c|c|c|}
\hline \multirow[b]{2}{*}{ Configuration } & \multirow[b]{2}{*}{ Description } & \multicolumn{3}{|c|}{1982} & \multicolumn{3}{|c|}{1992} \\
\hline & & 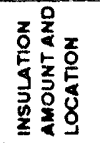 & 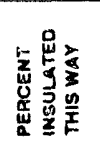 & 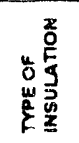 & 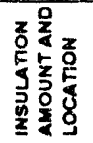 & 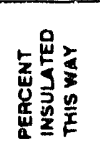 & 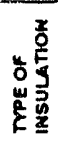 \\
\hline
\end{tabular}

\begin{tabular}{|c|c|c|c|c|c|c|c|}
\hline \multicolumn{8}{|c|}{ A. Concrete or masoniy foundation walle with exterior or Interior insulation } \\
\hline Exterior: half wall & \multirow{5}{*}{$\begin{array}{l}\text { NO INSULATION } \\
\text { A FT:R-5 RIGID } \\
\text { A FT:R-10 RIGID } \\
\text { OTHER }\end{array}$} & \multirow{5}{*}{$\begin{array}{l}0 \\
0 \\
0 \\
0\end{array}$} & \multicolumn{2}{|l|}{$88 \%$} & \multirow{5}{*}{$\begin{array}{l}0 \\
0 \\
0 \\
0\end{array}$} & \multicolumn{2}{|l|}{$62 \%$} \\
\hline & & & 1 & c & & 3 & a \\
\hline & & & 5 & $\mathrm{C}$ & & 4 & $c$ \\
\hline & & & 0 & - & & 2 & d \\
\hline \multicolumn{5}{|l|}{ I } & & & \\
\hline \multirow{5}{*}{ Exterior: full wall } & \multirow{5}{*}{$\begin{array}{l}\text { 8 FT:R-5 RIGID } \\
\text { 8 FT:R-1O RIGID } \\
\text { 8 FT:R-15 RIGID } \\
\text { 8 FT:R-20 RIGID }\end{array}$} & \multirow{5}{*}{$\begin{array}{l}0 \\
0 \\
0 \\
0 \\
0\end{array}$} & \multicolumn{2}{|r|}{ a, c } & \multirow{5}{*}{$\begin{array}{l}0 \\
0 \\
0 \\
0 \\
0\end{array}$} & 7 & $a, c$ \\
\hline & & & 1 & C & & 3 & c \\
\hline & & & 0 & - & & 0 & - \\
\hline & & & 0 & - & & 0 & - \\
\hline & & & 0 & e & & 1 & e \\
\hline Interior: full wall & \multirow{5}{*}{$\begin{array}{l}\text { 8 FT:R-6 RIGID } \\
\text { 8 FT:R-8 RIQID } \\
\text { 8 FT:R-11 BALL } \\
\text { B FT:R-19 BATT } \\
\text { OTHER }\end{array}$} & \multirow{5}{*}{$\begin{array}{l}0 \\
0 \\
\bigcirc \\
0\end{array}$} & 0 & \multirow{2}{*}{$\frac{c}{b}$} & \multirow{2}{*}{$\bigcirc$} & 1 & a \\
\hline & & & 1 & & & 3 & $b$ \\
\hline & & & 0 & b & 8 & 2 & $\mathrm{~b}$ \\
\hline$x=4$ & & & 3 & $\underline{b}$ & 0 & 6 & b \\
\hline 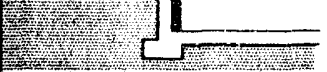 & & & 0 & b & 0 & 6 & b \\
\hline
\end{tabular}

\begin{tabular}{|c|c|c|c|c|c|c|c|}
\hline \multirow[t]{2}{*}{ Wood: full wall } & \multirow{5}{*}{$\begin{array}{l}\text { NO INSULATION } \\
\text { B FT:R-11 BATT } \\
\text { B FT:R-19 BATT } \\
\text { B FT:R-3O BATT } \\
\text { OTHER }\end{array}$} & \multicolumn{3}{|c|}{$26 \%$} & \multirow{3}{*}{$\begin{array}{l}0 \\
0\end{array}$} & \multirow{2}{*}{$\frac{28 \%}{14}$} & \\
\hline & & 0 & 18 & $b$ & & & b \\
\hline & & 0 & 26 & $\mathrm{~b}$ & & 20 & $\mathrm{~b}$ \\
\hline Ot & & 0 & 30 & b & 0 & 22 & b \\
\hline 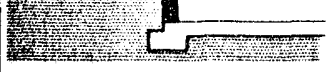 & & 0 & 0 & - & 0 & 16 & b \\
\hline
\end{tabular}

\begin{tabular}{|c|c|c|c|c|c|c|c|}
\hline \multirow{2}{*}{ Colling } & \multirow{2}{*}{$\begin{array}{l}\text { NO INSULATION } \\
\text { A FT:R-Y1 BATT }\end{array}$} & \multicolumn{3}{|c|}{$41 \%$} & \multicolumn{3}{|c|}{$32 \%$} \\
\hline & & 0 & 21 & $b$ & 0 & 20 & b \\
\hline Wutum & QFT:R-19 BATT & 0 & 26 & $b$ & 0 & 21 & $b$ \\
\hline 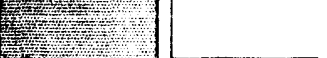 & BFT:R-3O BATT & 0 & 0 & - & 0 & 7 & b \\
\hline 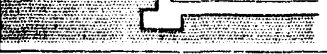 & OTHEF - & 0 & 12 & d & 0 & 20 & d \\
\hline
\end{tabular}

*Results: Question 2

$\mathrm{N}=2.5$

Note: Each percentage represents the average percentage of buildings indicated as insulated this way by the total respondents. Each letter represents the type of insulation most frequently indicated as used by the respondents. A dash represents no available data. 


\subsubsection{Crawl Space}

Table 3 shows the composite result of the 30 respondents who indicated they had some crawl spaces in their area. In 1982, $20 \%$ of crawl spaces had insulation either in the ceiling or on the walls of all nonvented crawl spaces, but this figure increased to $45 \%$ in 1992. When unvented crawl space walls were insulated, $80 \%$ of the time the insulation was on the inside wall in 1992. In 1982 and in 1992, only $27-33 \%$ of vented crawl spaces had insulation in the ceiling. The wording of this question did not enable the analysis to determine the percentage of crawl spaces that are ventilated and what percent are not ventilated.

\subsubsection{Slab-on-Grade}

Table 4 shows the composite result for the 23 respondents who indicated there were some slab-on-grade foundations in their area. In 1982, only $17 \%$ of slab-on-grade foundations were believed to have at least some insulation, but this figure increased to $60 \%$ in 1992. The data indicate that of those insulated in 1992, 12\% were insulated on the exterior of the foundation wall. The most common insulation location was on the inside vertical surface of the foundation wall (32\%). The dominant material used to insulate slabs was XEPS ("c") followed by EPS ("a"). The occasional indication that batts ("b") were the dominant material used to insulate slab edges suggested there may have been some confusion by several respondents when asked to identify insulation type.

\subsection{STRUCTURAL MATERIALS}

Poured concrete was indicated most frequently as the type of structural material used $(54 \%)$ and light concrete blocks were indicated least frequently $(6 \%)$. Question 3 should have specifically requested the type of structural material used to construct crawl space and basement walls. We believe that the slab-on-grade foundation, which is poured concrete, tends to overstate the percent of poured concrete used to construct foundation walls. The 
Table 3. How are you or others in your area insulating - Crawl Spaces? (Percent of Total)*

\begin{tabular}{|c|c|c|c|c|c|c|c|}
\hline \multirow[b]{2}{*}{ Configuration } & \multirow[b]{2}{*}{ Description } & \multicolumn{3}{|c|}{1982} & \multicolumn{3}{|c|}{1992} \\
\hline & & 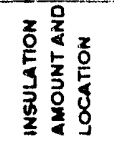 & 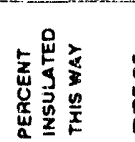 & 橧 & 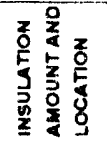 & 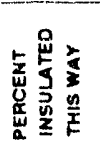 & 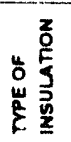 \\
\hline
\end{tabular}

A. Unvented crawl space - concrete or masonry foundation walls with exterior or interior Insiulation

\begin{tabular}{|c|c|c|c|c|c|c|c|}
\hline \multirow{4}{*}{ Exterior: vertical } & \multirow{4}{*}{$\begin{array}{l}\text { NO INSULATION } \\
2 \text { FT:R-5 RIGID } \\
2 \text { FT:R-1O RIGID } \\
\text { OTHER }\end{array}$} & \multicolumn{3}{|c|}{$80 \%$} & \multicolumn{3}{|c|}{$55 \%$} \\
\hline & & & 2 & C & & 4 & c \\
\hline & & $\Omega$ & 3 & C & 0 & 3 & c \\
\hline & & 0 & 1 & - & 0 & 2 & C \\
\hline \multicolumn{8}{|l|}{ Interlor: vertical } \\
\hline & \multirow{3}{*}{$\begin{array}{l}2 \text { FT:R-5 RIGID } \\
2 \text { FT:R-10 RIGID } \\
\text { OTHER }\end{array}$} & \multirow{3}{*}{$\begin{array}{l}0 \\
0 \\
0\end{array}$} & \multirow{3}{*}{$\frac{2}{3}$} & \multirow{3}{*}{$\frac{a, c}{\frac{c}{b}}$} & \multirow{3}{*}{$\begin{array}{l}0 \\
0 \\
0\end{array}$} & 6 & $a, c$ \\
\hline & & & & & & 6 & c \\
\hline & & & & & & 4 & $b$ \\
\hline \multirow{3}{*}{$\begin{array}{l}\text { Interior: vertical } \\
\text { and horizonfal }\end{array}$} & \multirow{5}{*}{$\begin{array}{l}2 \text { FT/2 FT:R-5 RIGID } \\
2 \text { FT/4 FT: R-5 RIG!D } \\
2 \text { FT/2 FT:R-10 RIGID } \\
2 \text { FT/4 FT: R-10 RIGID } \\
\text { OTHER }\end{array}$} & \multirow{5}{*}{$\begin{array}{l}0 \\
0 \\
0 \\
0 \\
0\end{array}$} & 3 & - & 0 & 2 & C \\
\hline & & & 3 & C & 0 & 5 & $c$ \\
\hline & & & 0 & $=$ & $\Omega$ & 4 & c \\
\hline & & & 0 & & $\Omega$ & 6 & $b$ \\
\hline 和 & & & 1 & $\mathrm{~b}$ & 0 & 3 & $b$ \\
\hline
\end{tabular}

B: Unvented crawl space - pressure-treated wood foundation walls

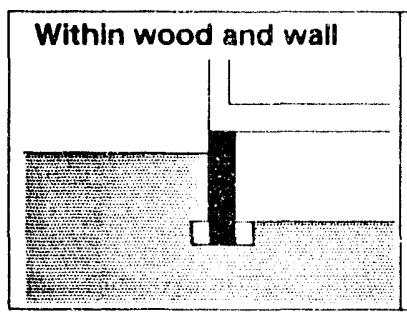

NO INSULATION
2 FT: R-19 BATT
OTHER

$\begin{array}{lll}0 & \frac{98 \%}{1} & - \\ 0 & \frac{b}{b} & \frac{b}{b} \\ 0 & \frac{1}{0} & - \\ 0 & \frac{1}{100 \%} & \end{array}$

$\begin{array}{lll}0 & \frac{90 \%}{4} & \frac{b}{b} \\ 0 & \frac{4}{2} & \frac{b}{e} \\ 0 & -\frac{e}{-}\end{array}$

C: Vented crawl space - concrete or masonry foundation walls with ceiling insulation

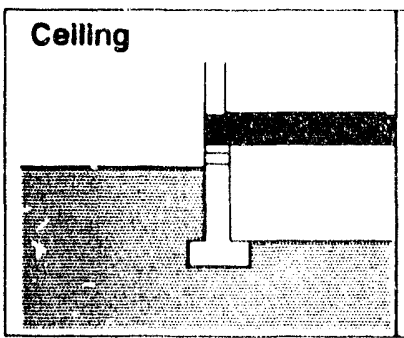

*Results: Question 2

\begin{tabular}{l|ccc|} 
NO INSULATION & 0 & $73 \%$ & \\
$\begin{array}{l}\text { R-11 BATT } \\
\text { A-19 BATT }\end{array}$ & 0 & $\frac{11}{8}$ & $\frac{\mathrm{b}}{\mathrm{b}}$ \\
R-30 BATT & 0 & $\frac{8}{4}$ & $\frac{\mathrm{b}}{\mathrm{d}}$ \\
OTHER & 0 & $\frac{4}{\mathrm{~d}}$ &
\end{tabular}

$100 \%$ $100 \%$

$\mathbf{N}=30$

Note: Each percentage represents the average percentage of buildings indicated as insulated this way by the total respondents. Each letter represents the type of insulation most frequently indicated as used by the respondents. A dash represents no available data. 
Table 4. How are you or others in your area insulating - Slab-on-Grade Foundations? (Percent of Total)*

\begin{tabular}{|c|c|c|c|c|c|c|}
\hline \multirow[b]{2}{*}{ Configuration } & \multirow[b]{2}{*}{ Description } & \multicolumn{3}{|c|}{1982} & \multicolumn{2}{|c|}{1992} \\
\hline & & 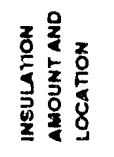 & 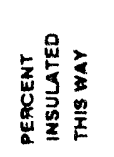 & 垈 & 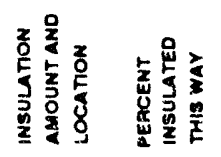 & 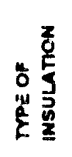 \\
\hline Exterior: vartical & $\begin{array}{l}\text { NO INSULATION } \\
2 \text { FT:R-5 } \\
2 \text { FT:R-10 } \\
4 \text { FT:R-5 } \\
4 \text { FT:R-10 } \\
4 \text { FT:R-15 } \\
4 \text { FT:R-20 } \\
\text { OTHER }\end{array}$ & & $\frac{\frac{83 \%}{1}}{\frac{2}{1}}$ & $\begin{array}{l}\frac{a}{d c} \\
c \\
c \\
c \\
d \\
- \\
-\end{array}$ & $\begin{array}{ll}0 & \frac{40 \%}{4} \\
0 & \frac{6}{3} \\
0 & \frac{2}{0} \\
0 & \frac{0}{3} \\
0 & \frac{1}{1} \\
\end{array}$ & $\begin{array}{l}\frac{a}{c} \\
c \\
c \\
\frac{a}{c} \\
d\end{array}$ \\
\hline Interior: vartical & $\begin{array}{l}2 \text { FT: R-5 } \\
2 \text { FT:R-10 } \\
4 \text { FT:R-5 } \\
4 \text { FT:R-10 } \\
4 \text { FT:R-15 } \\
4 \text { FT:R-20 } \\
\text { OTHER }\end{array}$ & & $\frac{\frac{1}{1}}{\frac{0}{\frac{1}{0}}}$ & $\begin{array}{l}\frac{a}{c} \\
\frac{c}{c} \\
b \\
\frac{-}{b} \\
- \\
\end{array}$ & $\begin{array}{l}\frac{4}{3} \\
\frac{3}{2} \\
\frac{2}{0} \\
7 \\
1 \\
\end{array}$ & $\begin{array}{l}a \\
\frac{a}{c} \\
\frac{c}{c} \\
\frac{-}{b} \\
\frac{d}{d}\end{array}$ \\
\hline Interior: horizontal & $\begin{array}{l}2 \text { FT: R-5 } \\
2 \text { FT:R-10 } \\
4 \text { FT:R-5 } \\
4 \text { FT:R-10 } \\
\text { OTHER }\end{array}$ & $\begin{array}{l}0 \\
0 \\
0 \\
0 \\
0\end{array}$ & $\frac{\frac{1}{1}}{-\frac{1}{0}} \frac{0}{1}$ & $\begin{array}{l}\frac{a}{a} \\
c \\
- \\
d\end{array}$ & $\begin{array}{l}3 \\
4 \\
2 \\
4 \\
1\end{array}$ & $\begin{array}{l}a \\
\frac{c}{c} \\
c \\
\frac{c}{d}\end{array}$ \\
\hline Exterlor: horizontal & $\begin{array}{l}2 \text { FT: R-5 } \\
2 \text { FT:R-10 } \\
4 \text { FT:R-5 } \\
\text { 4 FT:R-10 } \\
\text { OTHER }\end{array}$ & $\begin{array}{l}0 \\
0 \\
0 \\
0 \\
0\end{array}$ & $\begin{array}{l}\frac{1}{3} \\
\frac{0}{0} \\
0 \\
\end{array}$ & $\begin{array}{l}\frac{a}{c} \\
\frac{c}{-} \\
c \\
-\end{array}$ & $\begin{array}{l}\frac{2}{-4} \\
\frac{0}{-\frac{1}{0}} \\
0\end{array}$ & $\begin{array}{l}a \\
c \\
c \\
c \\
c \\
c\end{array}$ \\
\hline
\end{tabular}

Note: Each percentage represents the average percentage of buildings indicated as insulated this way by the total respondents. Fach letter represents the type of insulation most frequently indicated as used by the respondents. A dash represents no available data. 


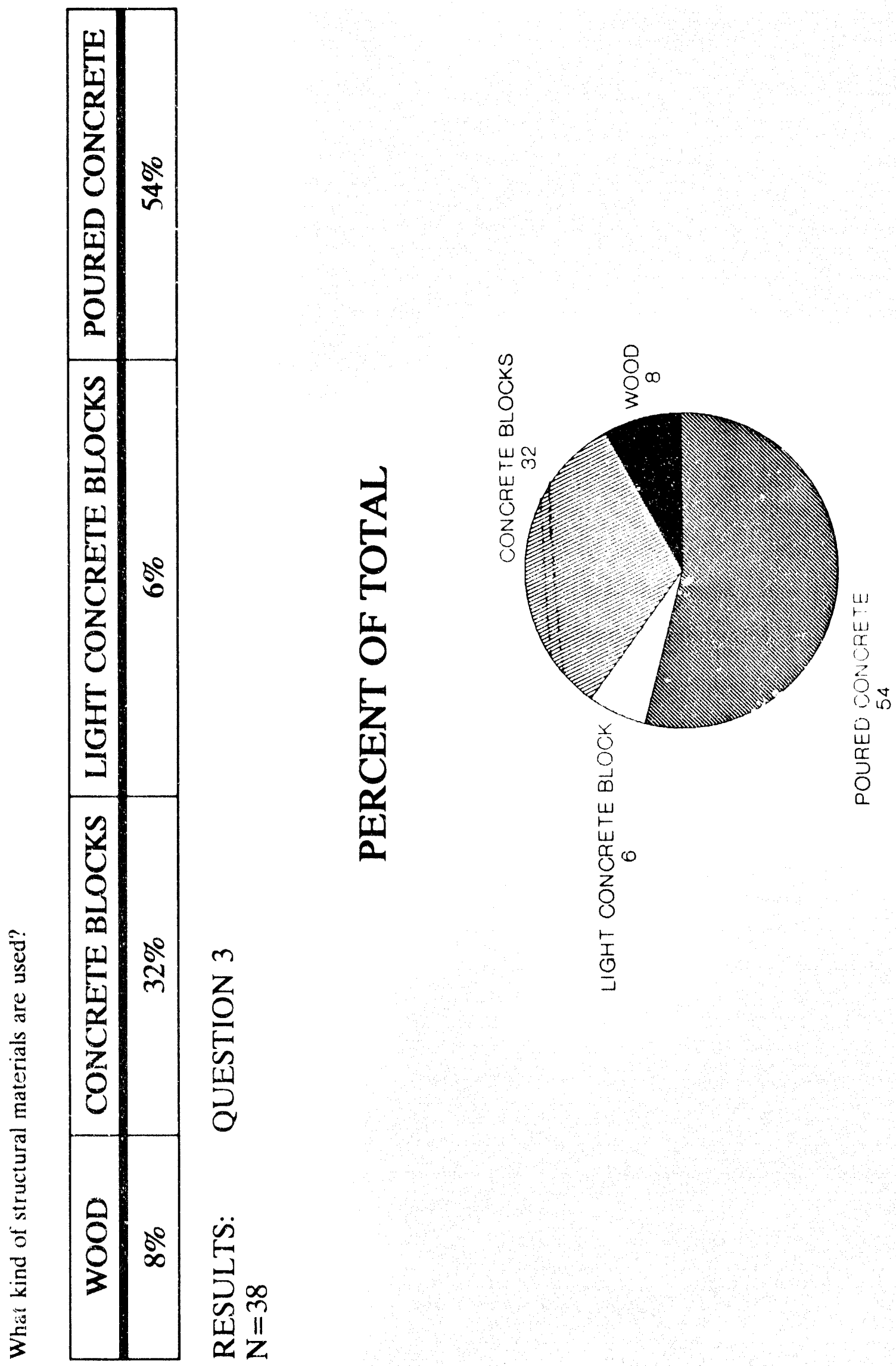

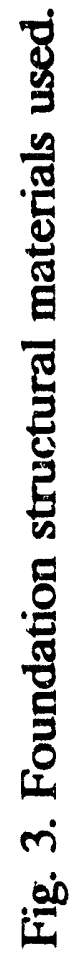


composite data, shown in Fig. 3, suggest that the largest single structural material used, following poured concrete, is normal weight concrete blocks (32\%). Other market data suggest that wood foundations make up $2 \%$ of structural materials used for foundations, so the $8 \%$ for wood found in this survey is high.

\subsection{INSECT CONTROL IMPACTS}

One frequently voiced reason why foundation insulation is not installed is the concern that insect control around building foundations will be compromised. Several termite control contractors will not guarantee their work when exterior insulation extends above grade, providing hidden passage of termites to above-grade wood.

The results from Question 4 (shown in Fig. 4) clearly indicate that this is predominantly a concern in the southern United States. The composite data indicate that only $32 \%$ feel this is a concern in their area. However, $57 \%$ of the seven respondents from the southeast and southwest regions were concerned about foundation insulation location affecting insect-control techniques. With the predominance of monolithic poured slab-ongrade foundations in the South, as well as increasing health concerns, it is clear that many slab edges will not be insulated without an innovative technique for insulating this type of foundation. Pest control operators want a perimeter vision strip on the exterior edge of the foundation.

\subsection{PROTECTIVE COVERING}

The added task of installing a suitable protective covering for the above-grade portion of exterior-applied foundation insulation was another major reason builders often cited when asked why they didn't insulate foundations. Figure 5 shows the most common type of covering is stucco (35\%), followed by metal flashing (18\%) and pressure treated wood $(12 \%)$. Surprisingly, three respondents indicated they installed no protection, despite the fact that U.V. and mechanical abuse is likely to reduce the useful life of the itsulation. 


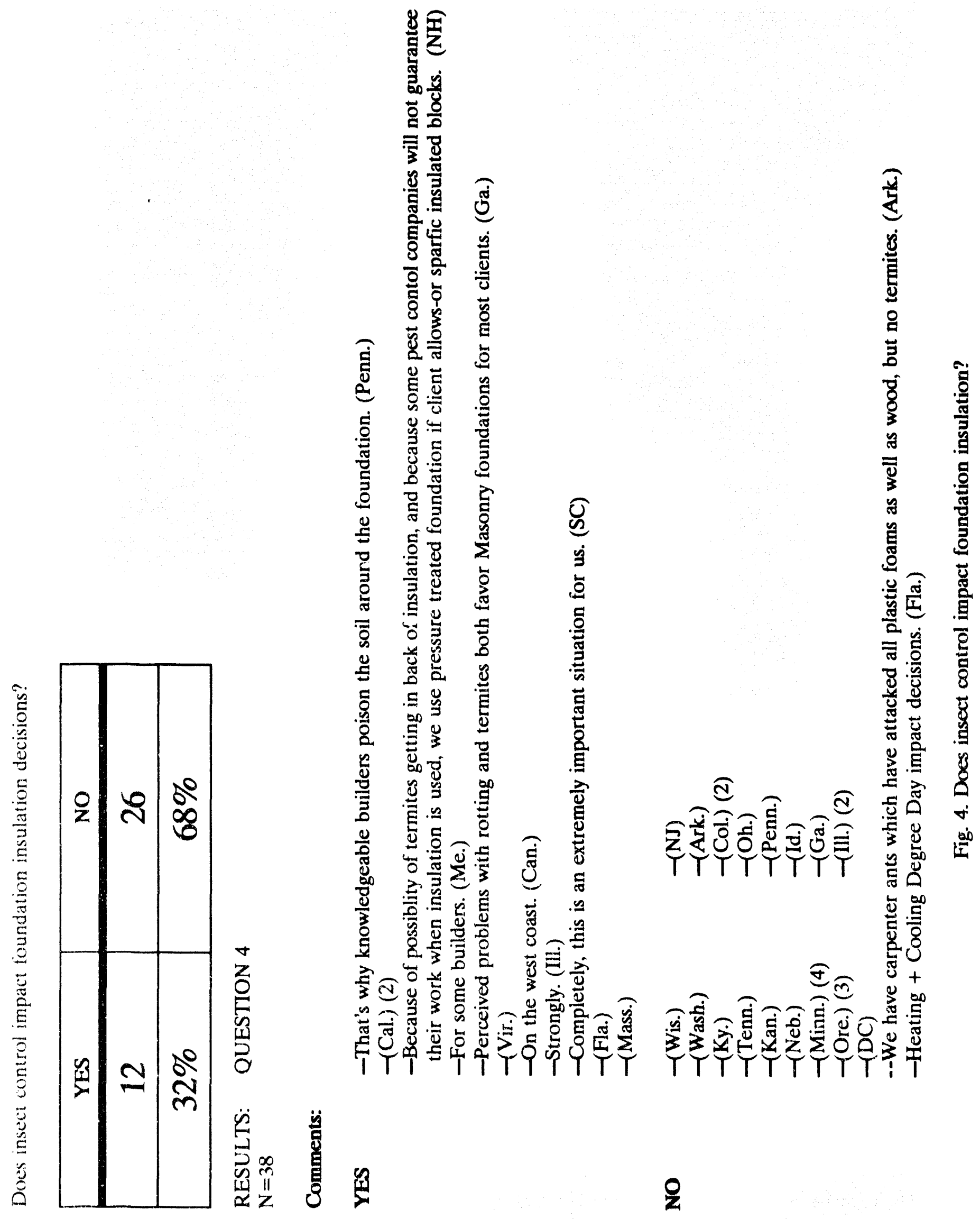




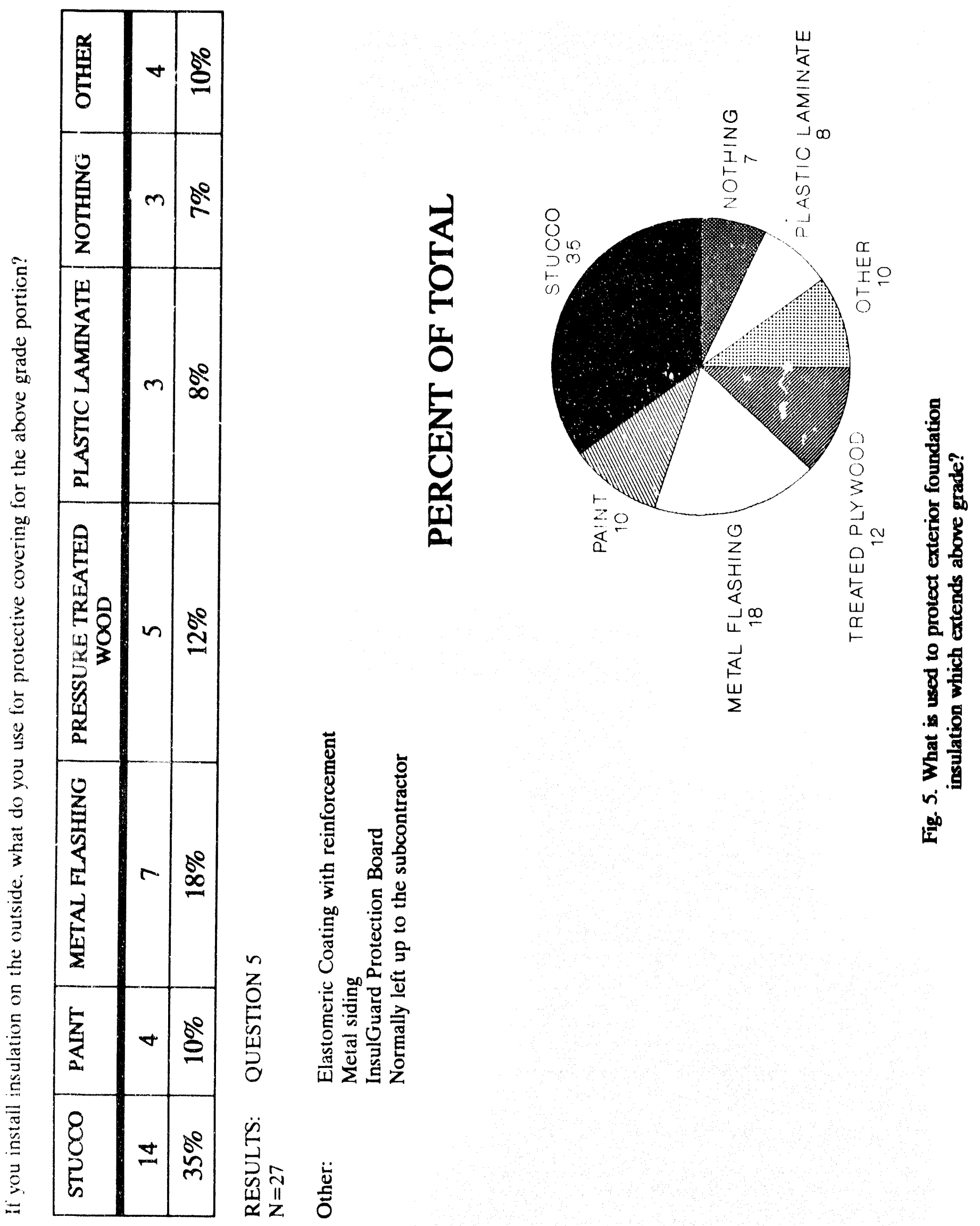


We received several comments regarding the need for further research on enhancing the durability of various protective covering systems. One respondent noted: "it has been my experience that stucco paint as protectors is not a permanent solution and fails within 2-3 years due to freeze/thaw cycles in Wisconsin." Another respondent observed that "many builders lack confidence in protective coverings for exterior insulation (high costs, lack of durability, aesthetic concerns)."

No single coating material seems to dominate. Readily available materials tend to be chosen more often than $\mathrm{sp}$ cialty products designed exclusively for this application.

\subsection{ENERGY CODES}

Figure 6 shows the composite results to Question 6, which examined the role of building energy codes and their enforcement in the increasing use of foundation insulation on new construction over the last ten years.

For 1982 only $14 \%$ of respondents reported enforced building codes; in 1992, 56\% reported the presence of an enforced code. It is interesting to look back at the increasing use of insulation reported in Question 2. The average increase in use of any type of foundation insulation rose from $17-26 \%$ to $45-60 \%$. There appears to be a strong correlation between enforced codes requiring foundation insulation and actual foundation insulation application.

Because DOE research activities over the last ten years have been used as the technical basis for increasing several national and state energy codes and standards, some credit for this increase in energy codes can justifiably be attributed to DOE efforts. Yet, in 1992, a large percentage of respondents (44\%) still reported no enforced foundation insulation requirement in their area, and responses to Question 2 indicated that $40-55 \%$ of the foundations were still not getting insulated. 

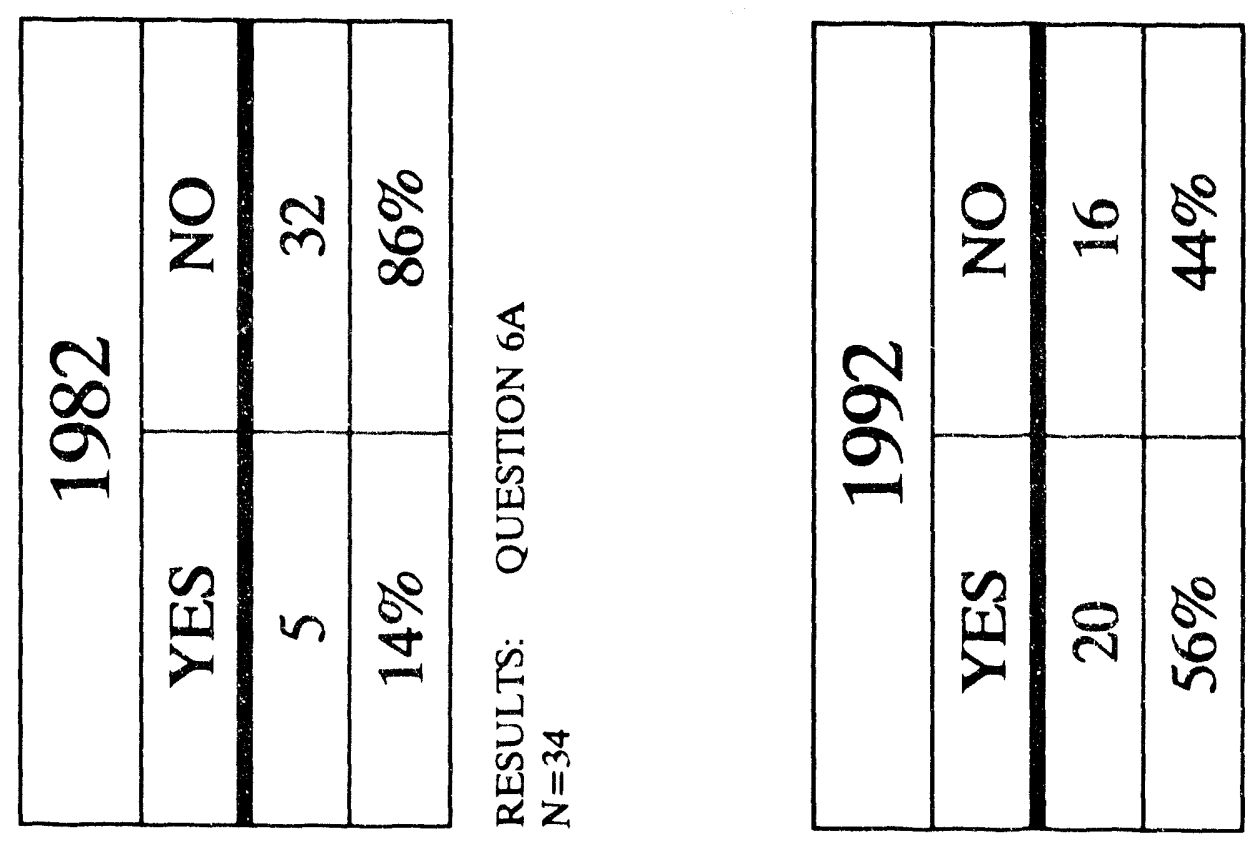

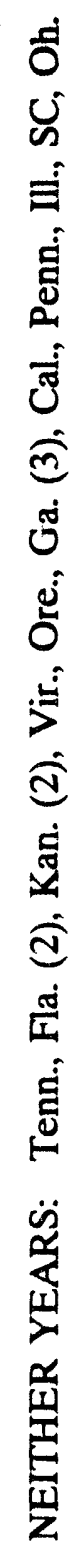




\subsection{HOW MUCH INSULATION?}

The second half of Question 6 generated some interesting information. One respondent reported that if you convert basements into habitable space in New Hampshire, the walls must be insulated. If this requirement could be successfully enforced nationwide, it would capture a large fraction of the existing building stock that currently doesn't have basement insulation. Unfortunately, owners frequently convert unconditioned basements to conditioned space and install inadequate insulation levels.

Another respondent noted that Wisconsin has just changed its code to require basement floor insulation. No available study has been conducted that has convincingly shown basement fioor insulation is cost effective 'rom an annual energy savings perspective, although several studies have claimed various degrees of thermal comfort enhancement.

Based on several comments from the Northwest, the most extensive levels of foundation insulation are required in this area, even more than in Wisconsin, Minnesota, and New England.

A final observation is that there are varying degrees of code enforcement, even within the same area. Figure 7 shows a listing of all the comments received from respondents to Questio.: 6.

\subsection{WHAT MOTIVATES FOUNDATION INSULATION DECISIONS?}

Question 7 asked i espondents if the insulation practice had changed in their area from 1982 to 1992 , and what had influenced these changes. This question attempted to identify what succeeded in motivating changes in insulation practice. Figure 8 shows results and comments resulting from this question. Obviously, enforced codes (32\%) and information that helps designers to economically justify the first cost of foundation 


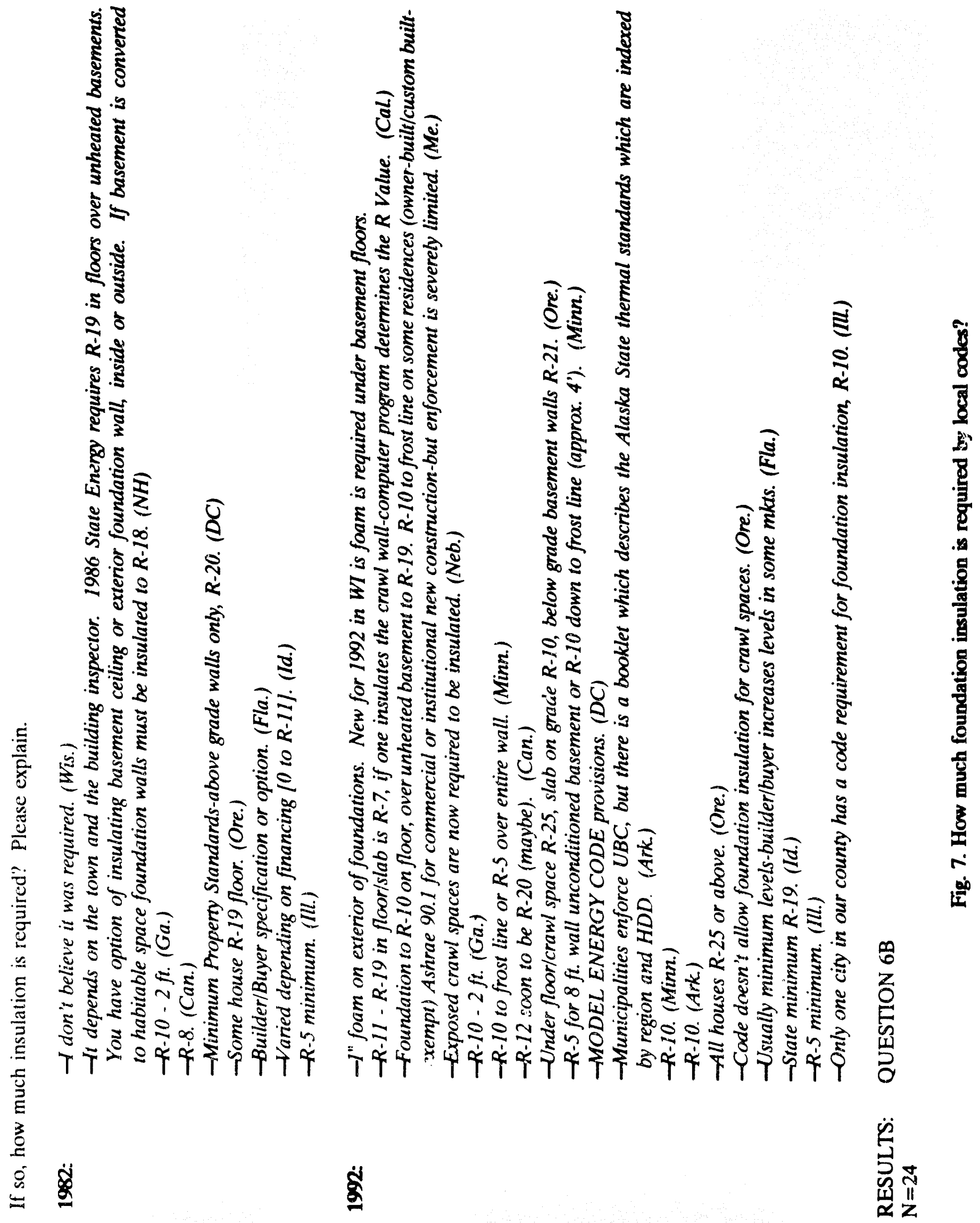



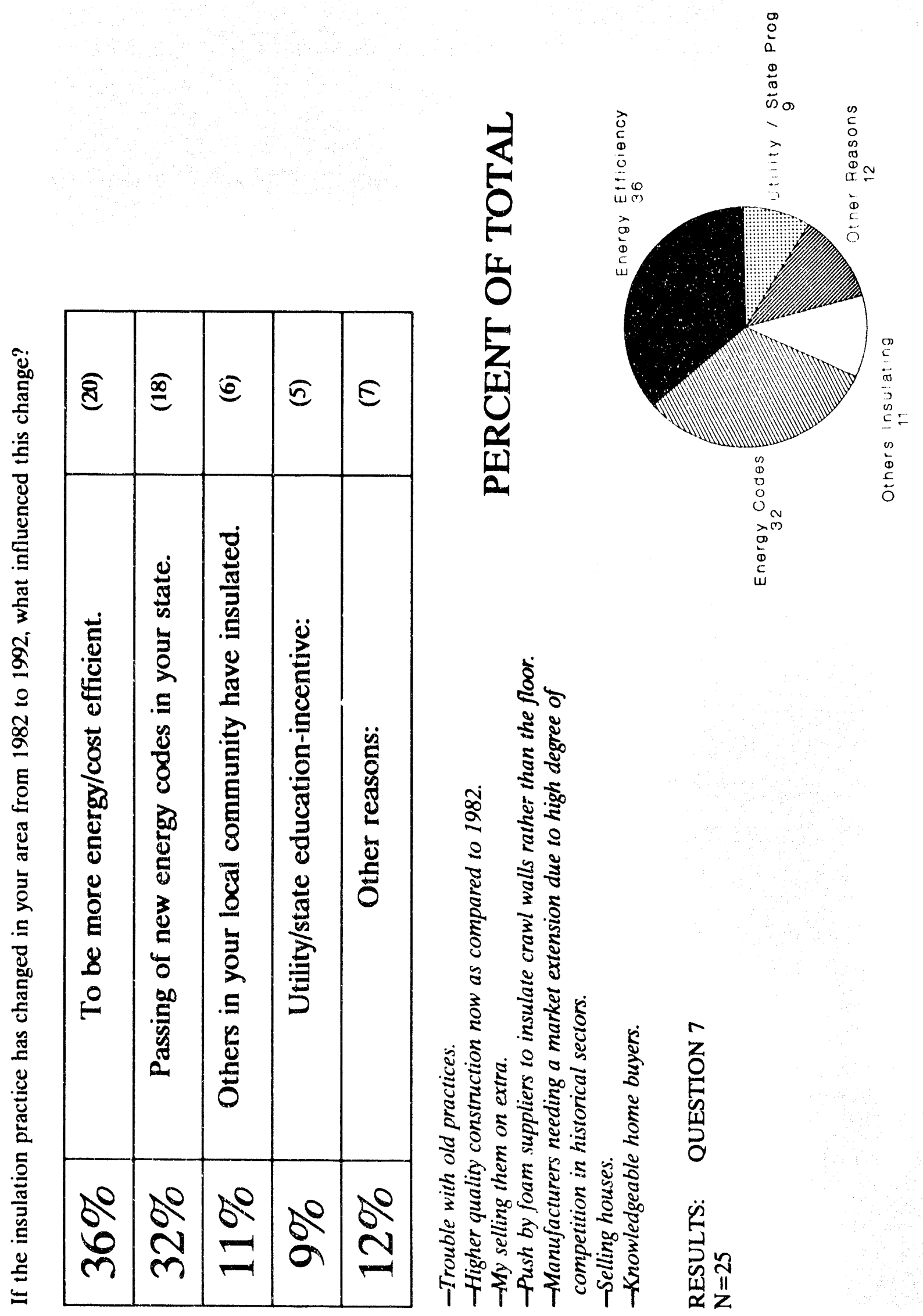

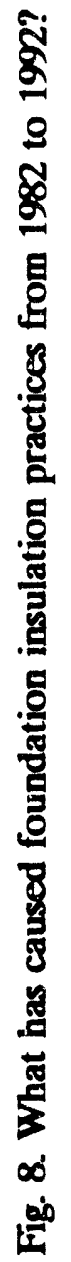

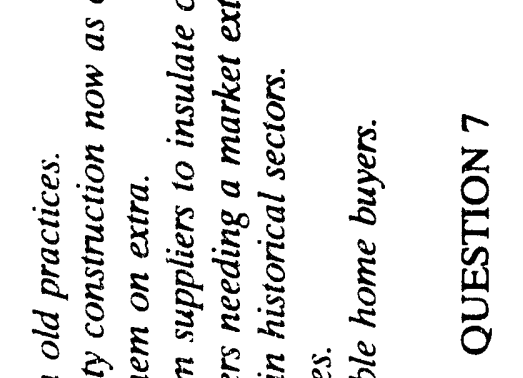

2.5.

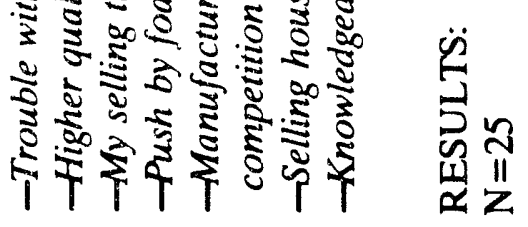


insulation (36\%) played a major role in the increasing use of foundation insulation. A popular write-in response not listed as an option on the survey was the impact of utility and state education and incentive programs (9\%).

\subsection{INFORMATION SOURCES}

Question 8 asked what information source was used when it was time to specify foundation insulation. Figure 9 shows results from this question. The largest single source used when deciding on foundation insulation guidance was government handbooks (41\%), and the Foundation and Moisture Control Handbooks were cited most frequently. Energy codes were the source $15 \%$ of the time, and research papers served as sources $11 \%$ of the time.

Question 9 tried to determine what could be done to attack those areas where foundation insulation is still not standard practice. The results shown in Fig. 10 suggest there is no single reason for not installing foundation insulation. In the mid 1980s, people frequently complained that there wasn't sufficient information, but that doesn't seem to be the problem in 1992. Reducing the added first cost would help encourage foundation insulation, and providing additional information on the relative maintenance cost of insulated versus uninsulated foundations might also make a difference. We base this observation on several of the comments. One respondent remarked that there was "no available correlation between cost of insulating and cost of retrofitting and repair (cracks, etc.)." Another respondent observed that "there is a lack of effective trouble-free systems."

From this point, foundation research should focus on technology development and demonstration instead of providing additional performance information on popular commercially available foundation systems. 


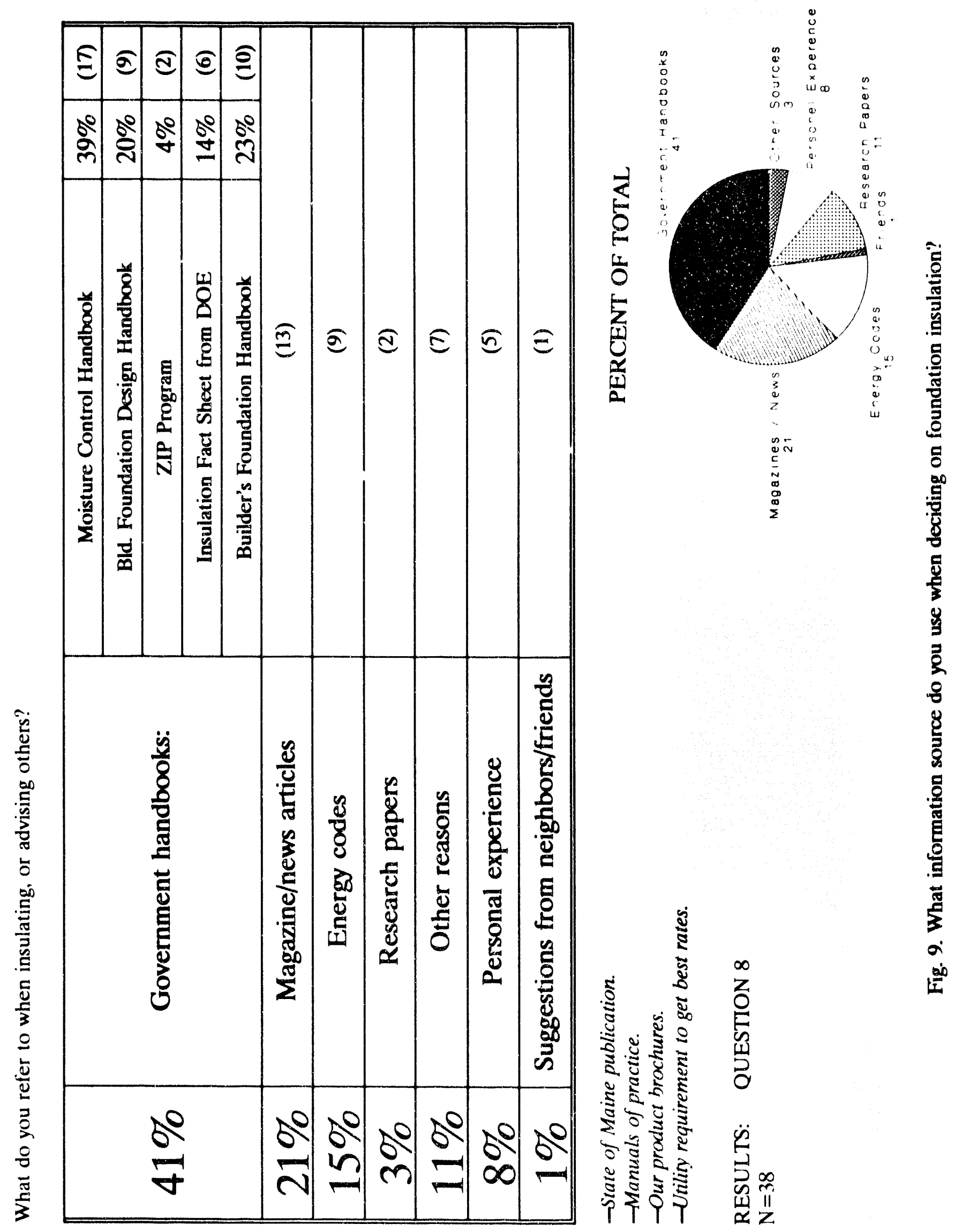



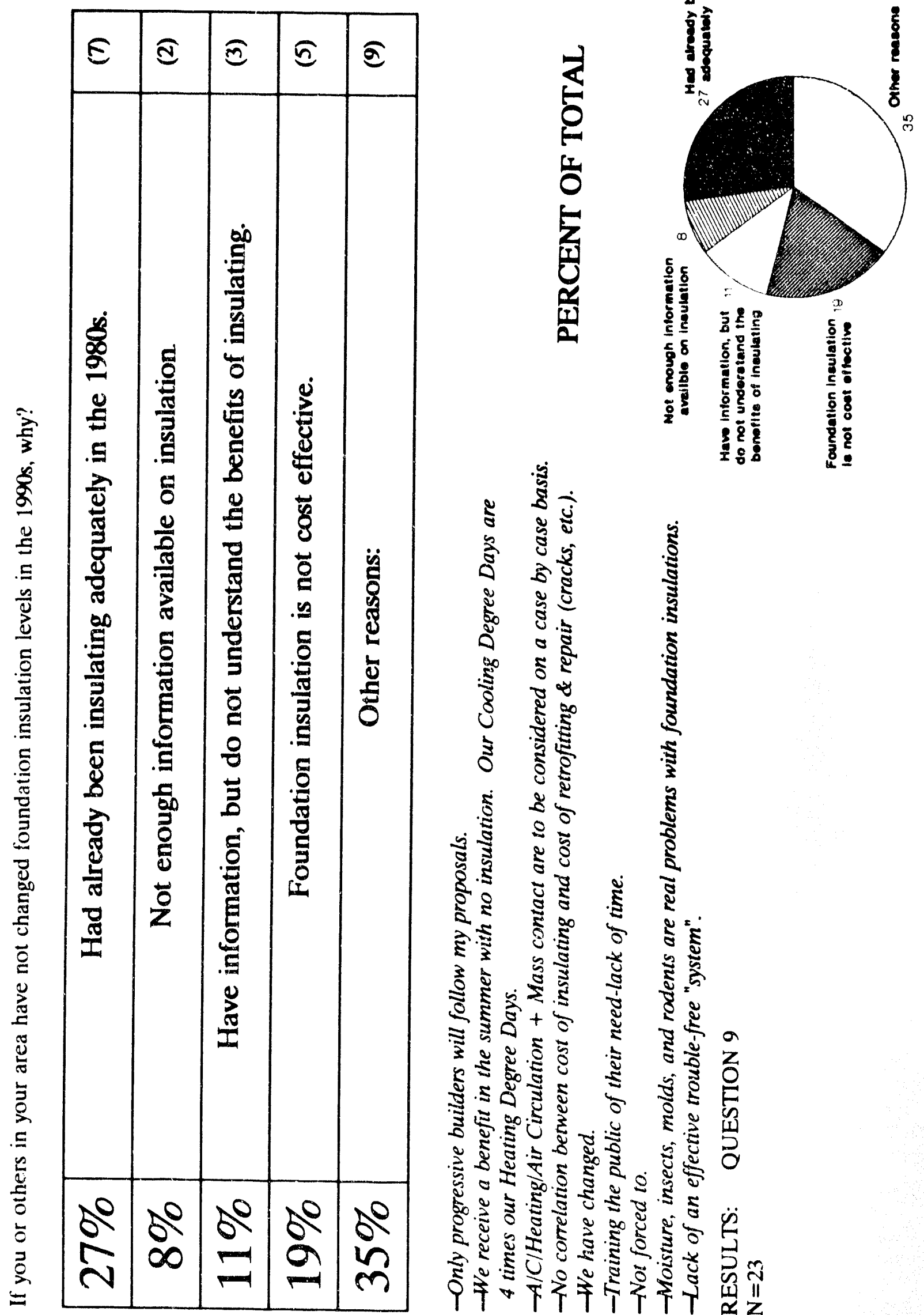

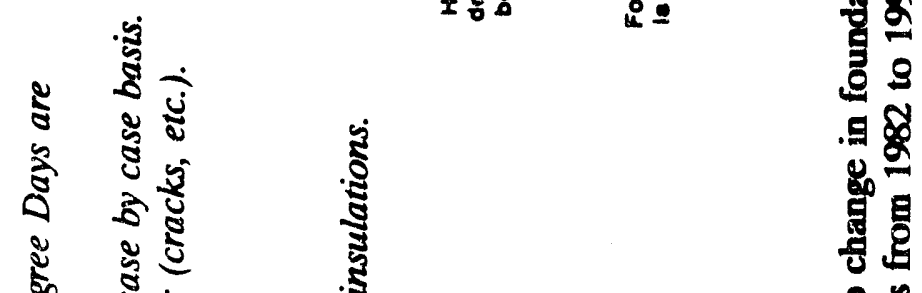

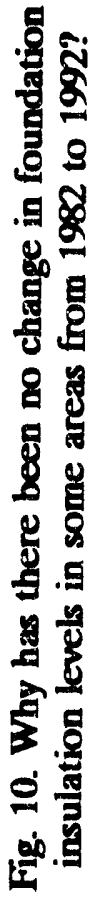

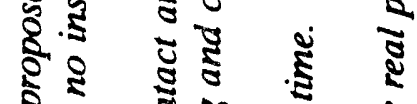

ริ

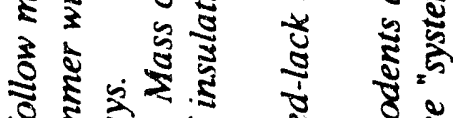

อ है

สิ

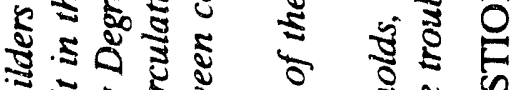

ปิ

में

20.

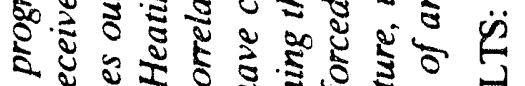

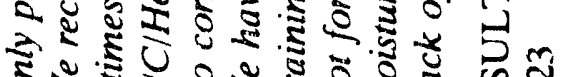

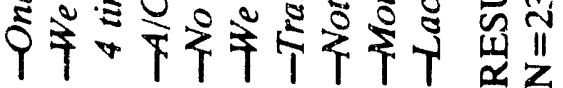




\subsection{RESEARCH ISSUES}

Question 10 was meant to help determine what research could lead to more complete acceptance of energy-efficient foundations. We identified several good suggestions for future work in the respondents' comments, which are shown in Fig. 11. Promising research areas gleaned from the comments are

1. Need for guidance on when not to ventilate crawl spaces.

2. How much insulation should be used around heated slabs.

3. Quantify the added benefit of thermal comfort resulting from foundation insulation above and beyond those levels justified solely on annual energy savings.

4. Develop a more cost-effective protective coating for exterior-applied insulations.

5. Positively pressurized basements and crawl spaces need study to determine optimum construction technique as well as moisture and radon control tffectiveness.

6. Spray-applied foundation insulations need study (foam, cellulose, and fiberglass). 


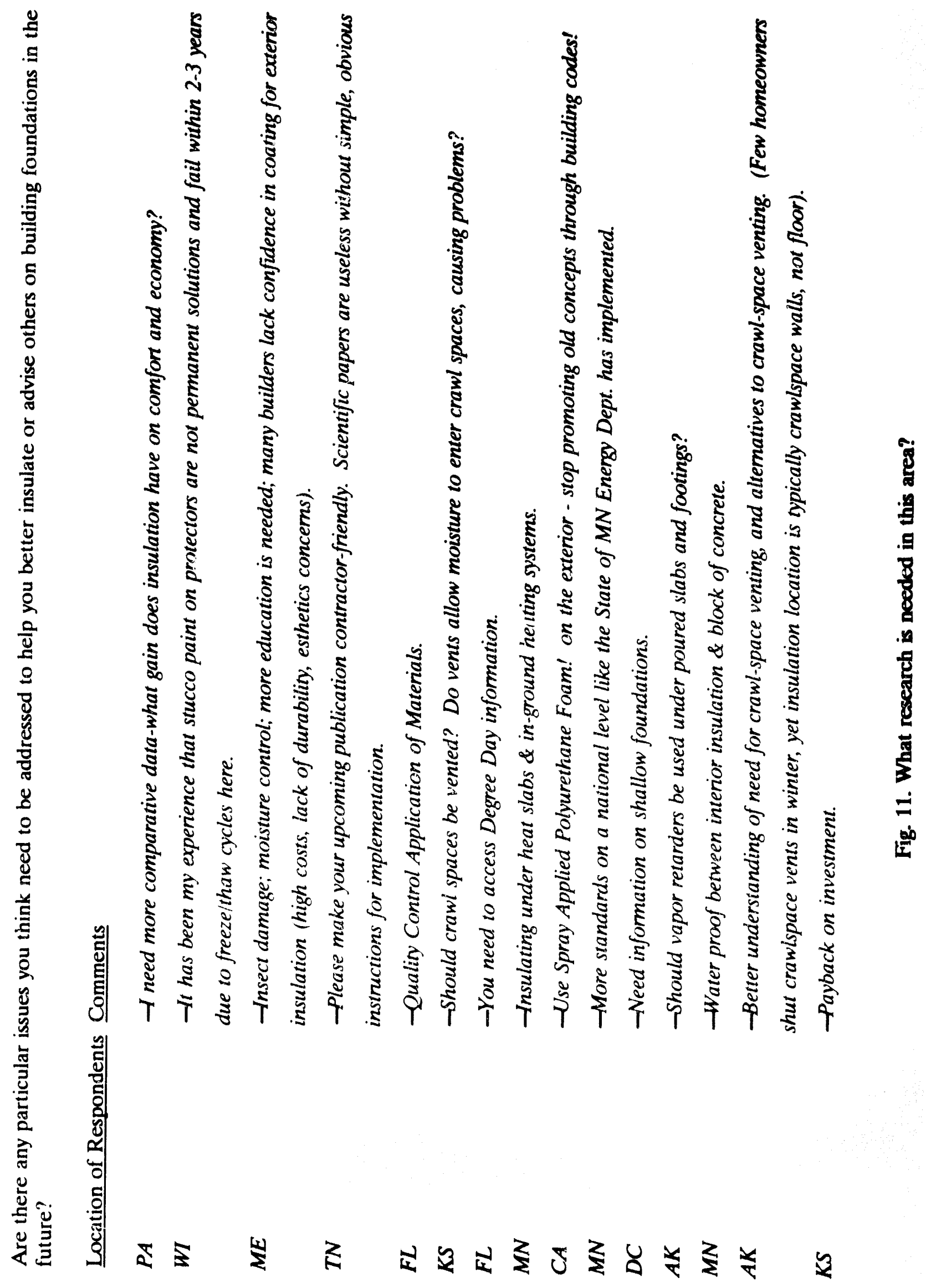




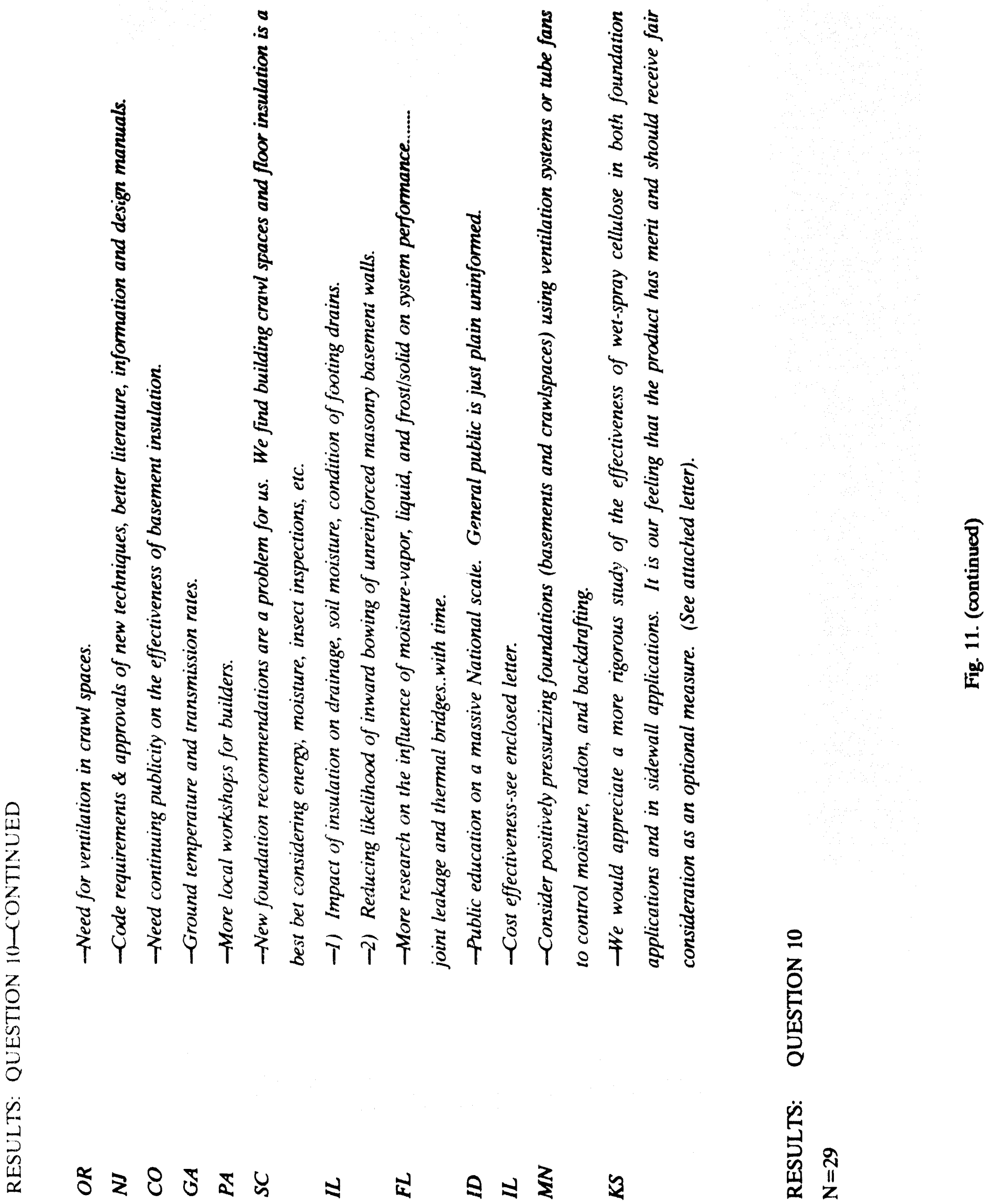




\section{GEOGRAPHIC BREAKDOWN}

We evaluated six of the seven regions separately from the composite data reported in Sect. 3. The small sample size prevented a meaningful evaluation for the Southwest. The results are shown graphically in Appendix B for all questions except number 2, which is in tabular form. In this section, we provide several observations about regions when their data deviates significantly from the composite data.

\subsection{SOUTHEAST}

Detailed results are shown in Fig. B-1 and Tables B.1-B.4. Because slab-on-grade tends to be the dominant construction in the Southeast, it is interesting to note that the respondents indicated $95 \%$ of the slabs in this area weren't insulated in new construction in 1982 and that nothing has changed in 1992, as Table B.4 shows. These results are consistent with the answer to Question 6 on whether codes are enforced, of which $88 \%$ said no in 1992.

\subsection{EAST}

Results are shown in Fig. B-2 and Tables B.5-B.8. The percent of conditioned basements with at least some insulation has increased in this region from $42 \%$ in 1982 to $80 \%$ in 1992. Because this area includes Washington, D.C., it is not surprising that this region more heavily depends on government handbooks to decide on how much insulation to use $(60 \%)$ compared with composite average of $41 \%$.

\subsection{NORTHEAST}

The six respondents from this area indicate in 1982 that almost nobody insulated conditioned deep basements (96\%), compared with 66\% in 1992. This suggests much energy is still being lost in this part of the country, which uses basement foundations almost exclusively. It is also interesting to note that $67 \%$ of the builders are concerned about 
foundation insulation affecting insect control, despite the predominant heating climate of the region.

Government handbooks are heavily used in this region as well (67\%). In 1992, 50\% of the areas had no enforced foundation insulation codes.

\subsection{MIDWEST}

Results are shown in Fig. B-4 and Tables B.13-B.16. In 1982 only $19 \%$ of the conditioned basement walls were insulated; in $199253 \%$ were insulated. Insect control is not an issue when deciding on how to insulate basements in the Midwest.

\subsection{WEST}

Results are shown in Fig. B-5 and Tables B.17-B.20. Slab-on-grade insulation grew from $7 \%$ in 1982 to $47 \%$ in 1992 . Building codes in this area were enforced in this region in 1982, and continued to be enforced in 1992.

\subsection{NORTHWEST}

Results from this region are shown in Fig. B-6 and Tables B.21-B.24. Insect control is not an issue when deciding on foundation insulation, but radon control is. Unvented crawl spaces are not permitted. Code enforcement increased significantly from only $11 \%$ in 1982 to $88 \%$ in 1992 . This area requires more foundation insulation than any other region of the country ( $R-25$ floor insulation, $R-10$ slab edge insulation, and R-21 basement wall insulation). 


\section{CONCLUSION}

This survey reports that more foundation insulation was being placed on new construction in 1992 than was being installed in 1982, from around $25 \%$ to about $50 \%$. It appears that stricter enforcement of foundation insulation requirements directly correlates with this increase. DOE foundation research provided the technical support for most of the changes in foundation insulation levels in national and state codes. DOE foundation research efforts also contributed significantly to this increase in energy-efficient foundations, because $41 \%$ of respondents reported that they used government handbooks to make foundation insulation decisions.

In some areas, as many as $67 \%$ of respondents reported government handbooks as major information sources. The two foundation and moisture control handbooks were most frequently cited as specific sources.

In the mid 1980s, a major reason most builders were not insulating foundations was a "lack of information and clear guidance." The development of the foundation handbooks and incorporation of research results into national and state codes changed this. These survey resulte reinforce the belief that a lack of information is no longer the major problem.

A more dedicated focus to practical cost-effective technology development and demonstration could make a difference in capturing the remaining $40-50 \%$ foundations that are not being insulated and should be. Several good research topics that merit further study include:

1. Need for guidance on when not to ventilate crawl spaces.

2. Optimum insulation configurations for heated slabs.

3. Quantified benefit of thermal comfort resulting from foundation insulation above and beyond those levels justified solely on annual energy savings.

4. Develop a more cost-effective protective coating for exterior-applied insulations. 
5. Positively pressurized basements and crawl spaces, optimum construction techniques, as well as moisture and radon control effectiveness.

6. Performance characterization of spray-applied foundation insulations (foam, cellulose, and fiberglass). 
APPENDIX A 
WAME:

ORGANIZATION:

OTY, STATE:

TELEPHONE NO:

DATE

1.) Please indicate which discipline best identifies your occupation or research.

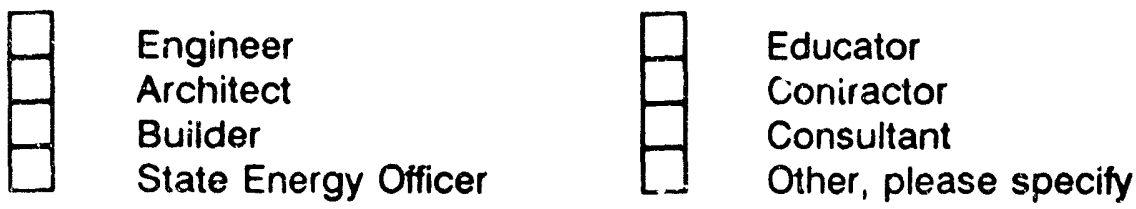

2.) The next few pages are referring to new buildings built in your area. Please indicate by looking at each configuration and description: the amount of insulation installed and location (by filling in the circles); the percent of new buildings insulated this way (by writing down the percentages); and the type of insulation (using the codes from the table beluw) for 1982 and 1992 . An example has been given.

\begin{tabular}{|lll|}
\hline & & \multicolumn{1}{c|}{ TYPE } \\
a.) & EPS & -Expanded Polystyrene, foam boards (white) \\
b.) & BATT & -Batts \\
c.) & XEPS & -Extruded Polystyrene, (blue, green, pink) \\
d.) & PI & -Polyisocanur .e \\
e.) & & -Other \\
\hline
\end{tabular}

Example-TABLE 1: How are you insulating - Conditioned Deep Basements?

\begin{tabular}{|c|c|c|c|c|c|}
\hline \multirow[b]{2}{*}{ CONFIGURATION } & \multirow[b]{2}{*}{ DESCAIPTION } & \multicolumn{2}{|c|}{1982} & \multicolumn{2}{|r|}{1992} \\
\hline & & 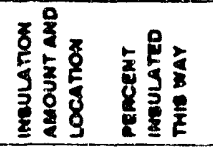 & $\begin{array}{l}8 \\
8 \\
8 \\
8 \\
8 \\
\end{array}$ & 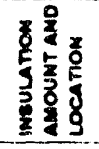 & 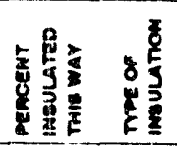 \\
\hline
\end{tabular}

A: Concrete or Masonry Foundetion Walls whth Exterior insulation

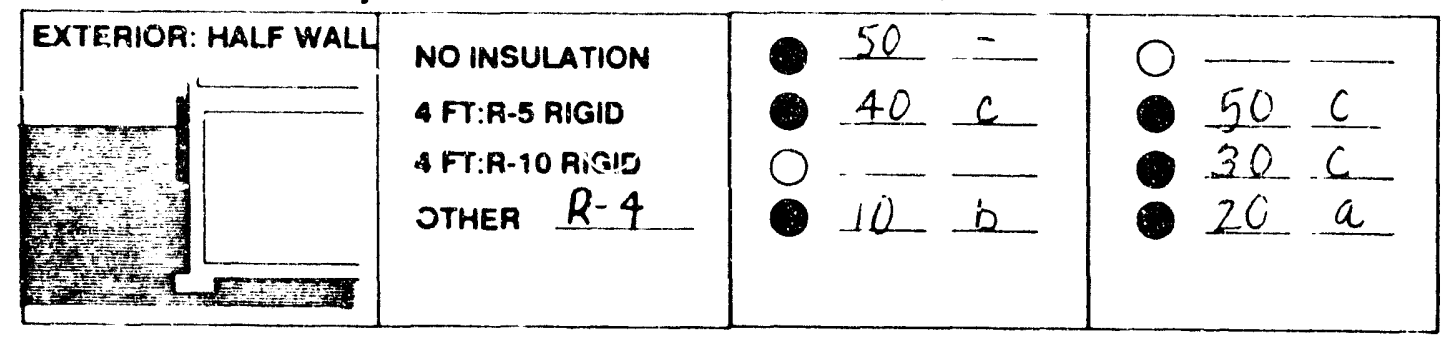


3.) What kind of structural materials are usid?

Wood

Concrete Blocks

Light Concrete Blocks

Poured Concrete

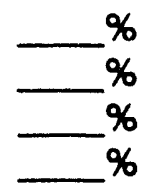

4.) Does insect contrul impact foundation insulation decisions?

5.) If you install insulation on the outside, what do you use for protective covering for the above grade portion?
a.) stucco
b.) paint
c.) metal flashing
d.) pressure treated plywood
e.) plaster laminate
f.) other

6a.) Are codes requiring foundation insulation enforc $d$ in your area?

1982
YES $\quad \begin{gathered}1992 \\ \text { YES } \\ \text { NO }\end{gathered}$

6b.) If so, how much insulation is required? Please explain.

1982:

1992

7.) If the insulation practice has changed in your area from 1982 to 1992 , what influenced this change?

To be more energy/cost efficient.

Passing of new energy codes in your state.

Others in your local cornmunity have insulated.

Other reason 
8.) What do you refer to when insulating, or advising others?

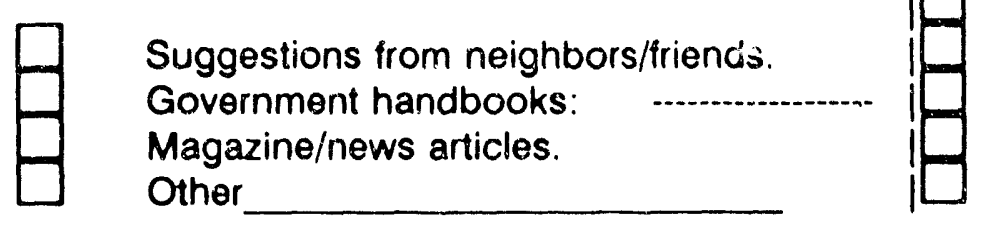

Moisture Control Handbook Building Foundation Design Handbook ZIP Program Insulation Fact Sheet from DOE Builder's Foundation Handbook

9.) If you or others in your area have not changed foundation insulation levels in the 1990's, why?

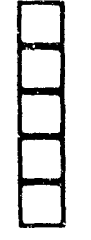

Had already been insulating adequately in the 1980's.

Not enough information available on insulation.

Have information, but do not understand the benefits of insulating.

Foundation insulation is not cost effective.

Other reason

10.) Are there any particular issues you think need to be addressed to help you better insulate or advise others on building foundations in the future?

THANK YOU VERY MUCH FOR YOUR COOPERATION, YOUR RESPONSES ARE APPRECLATED. 
Table A.1. How are you insulating - Conditioned Deep Basements?

\begin{tabular}{|c|c|c|c|c|c|c|c|}
\hline \multirow[b]{2}{*}{ Configeration } & \multirow[b]{2}{*}{ Description } & \multicolumn{3}{|c|}{1982} & \multicolumn{3}{|c|}{1992} \\
\hline & & 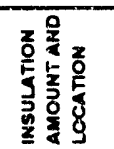 & 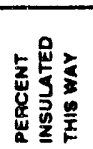 & 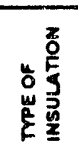 & 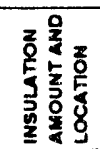 & 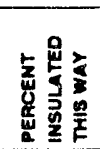 & 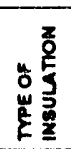 \\
\hline
\end{tabular}

A: Concrete or masonry foundation walls with exterior or Interior Insulation

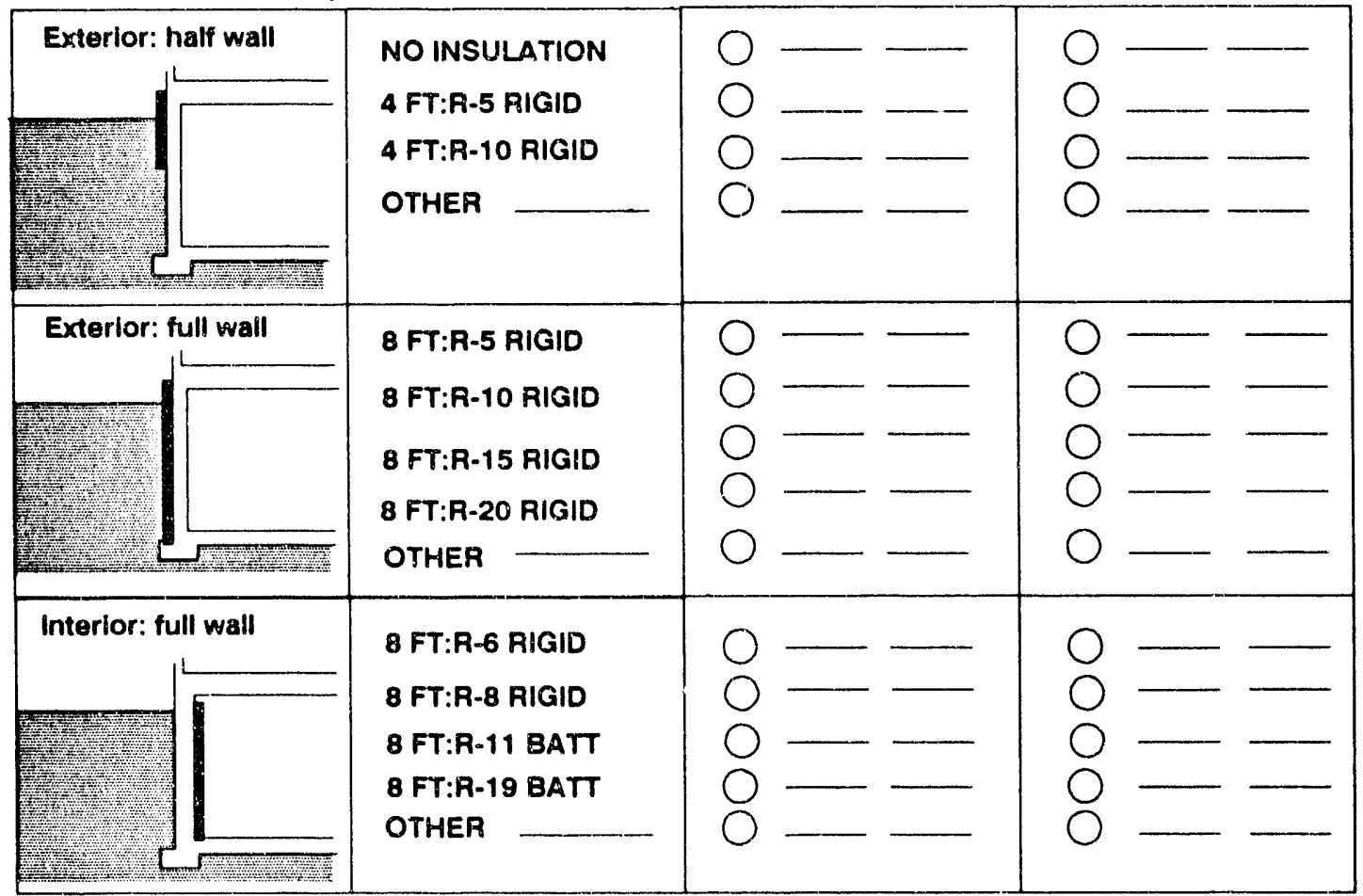

B: Pressure-treated wo. d foundation walls

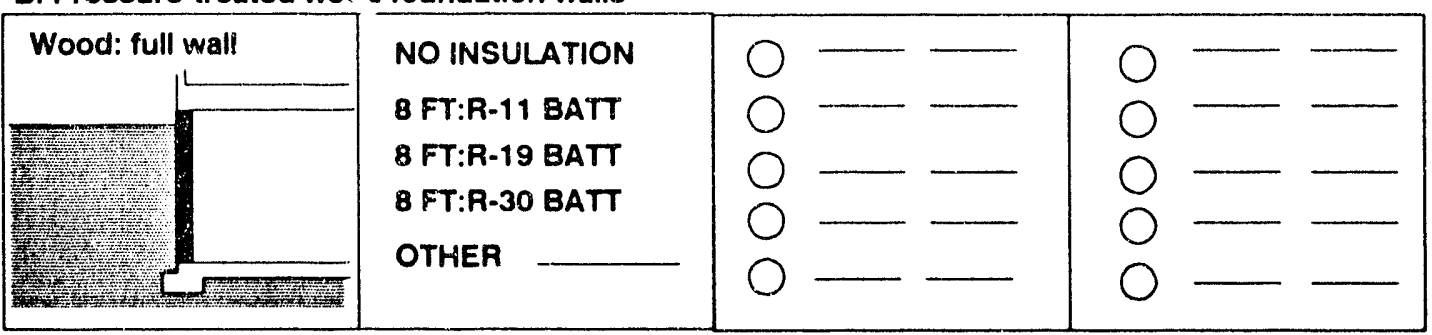


Table A.2. How are you insulating - Unconditioned Deep Basements?

\begin{tabular}{|c|c|c|c|c|c|c|c|}
\hline \multirow[b]{2}{*}{ Configeration } & \multirow[b]{2}{*}{ Description } & \multicolumn{3}{|c|}{1982} & \multicolumn{3}{|c|}{1992} \\
\hline & & 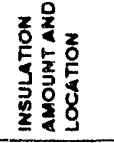 & 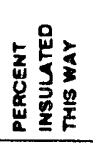 & 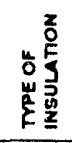 & 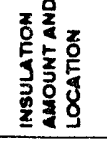 & 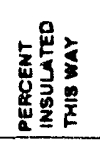 & 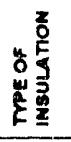 \\
\hline
\end{tabular}

A: Concrete or masonry foundation walls with exterior or Interior Insulation

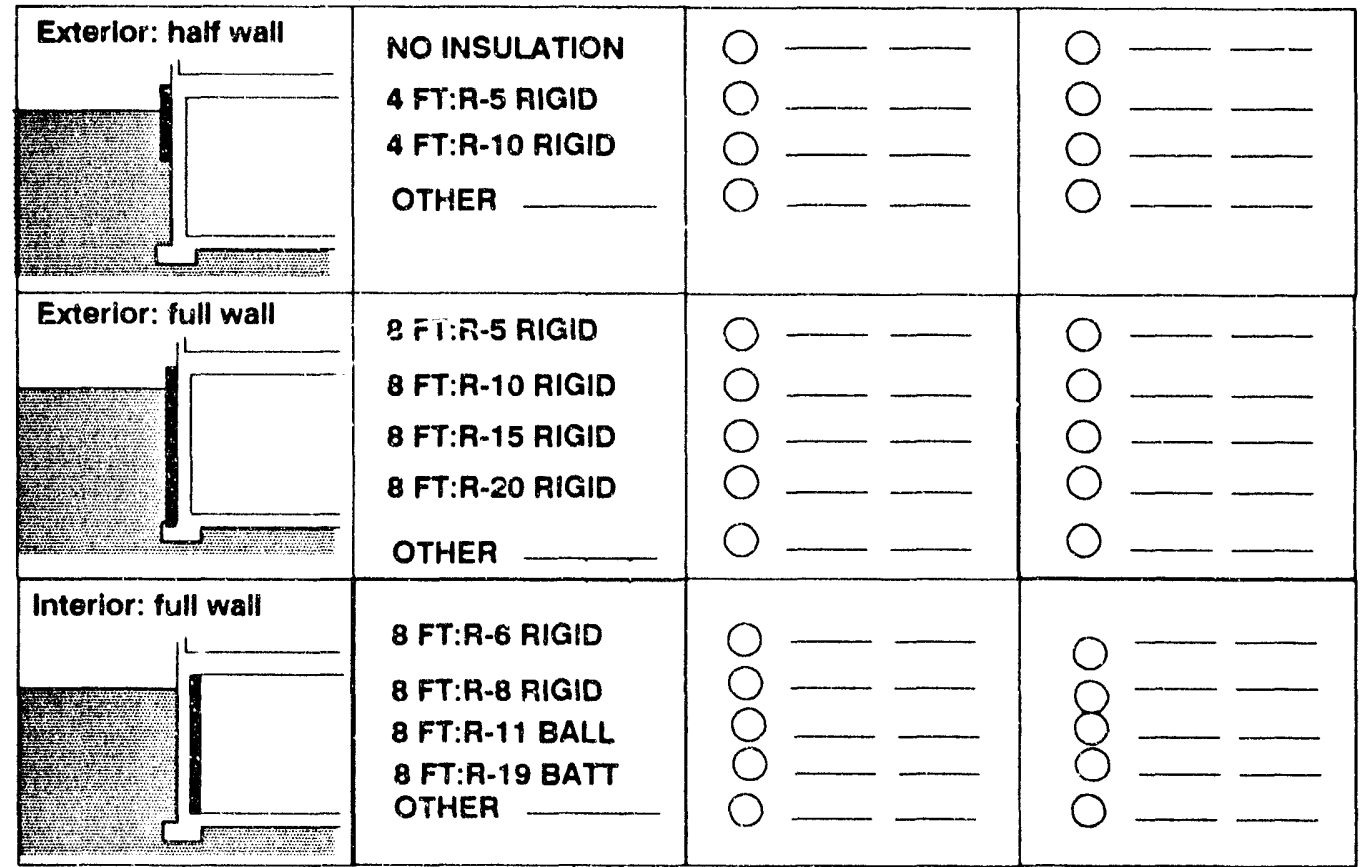

B: Pressure-ireated wood foundation walls

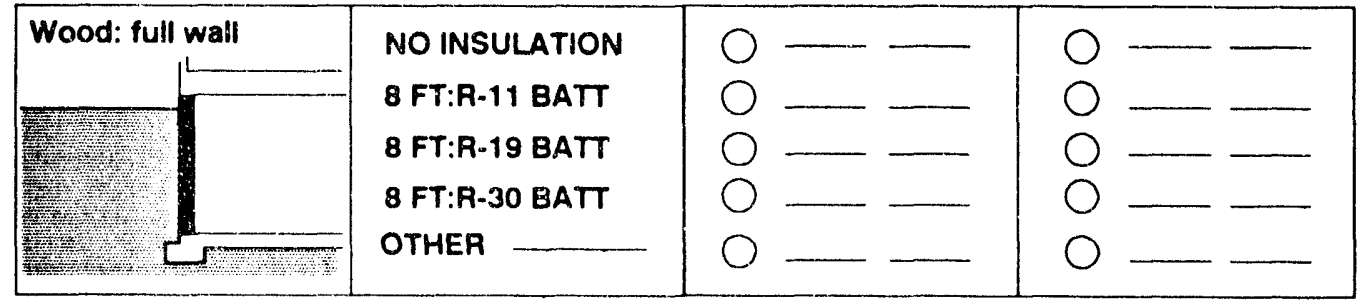

C: Concrete or masonry foundation walls with ceiling isulation

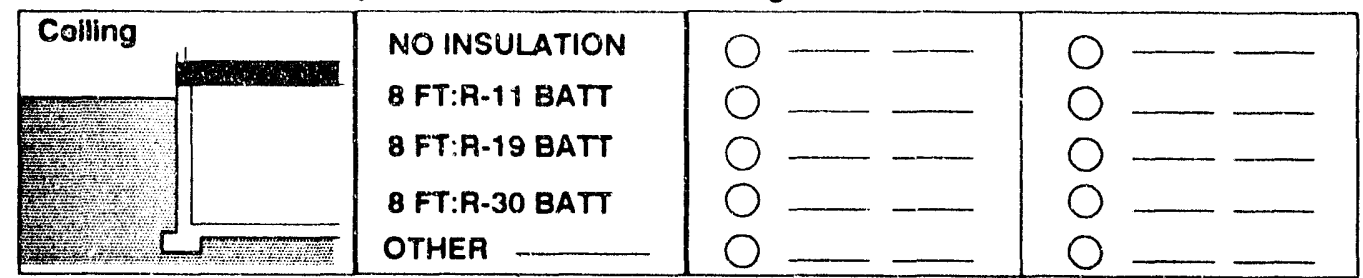


Table A.3. How are you insulating - Crawl Spaces?

\begin{tabular}{|c|c|c|c|c|c|c|c|}
\hline \multirow[b]{2}{*}{ Confligeration } & \multirow[b]{2}{*}{ Description } & \multicolumn{3}{|c|}{1982} & \multicolumn{3}{|c|}{1992} \\
\hline & & 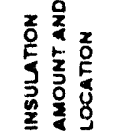 & 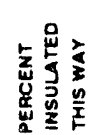 & 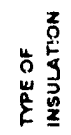 & 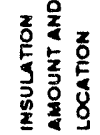 & 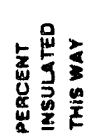 & 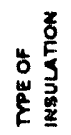 \\
\hline
\end{tabular}

A: Unvented crawi space - concrete or masonry foundation walls with exterior or interior insulation

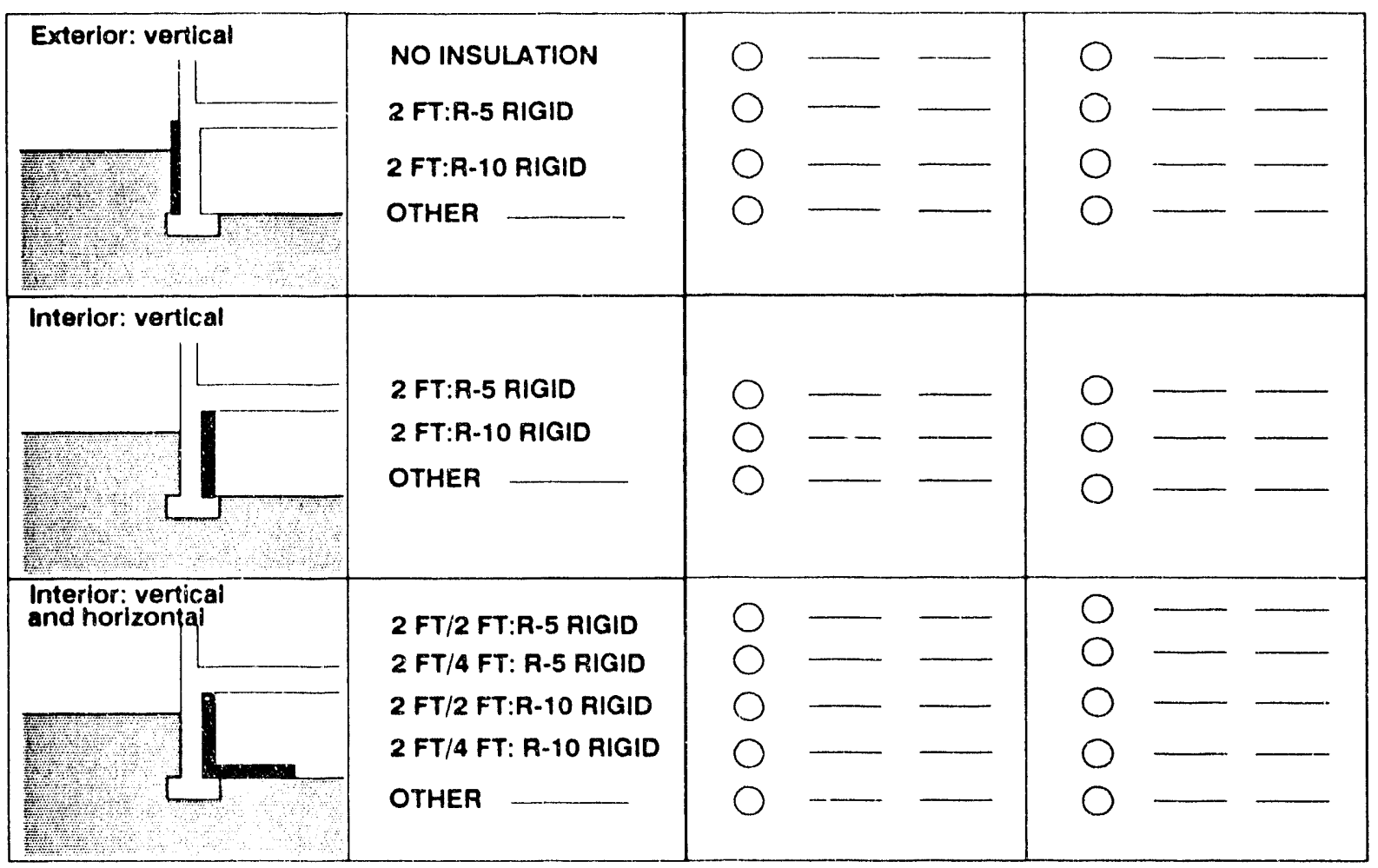

B: Unvented crawl space - pressure-treated wood foundation walls

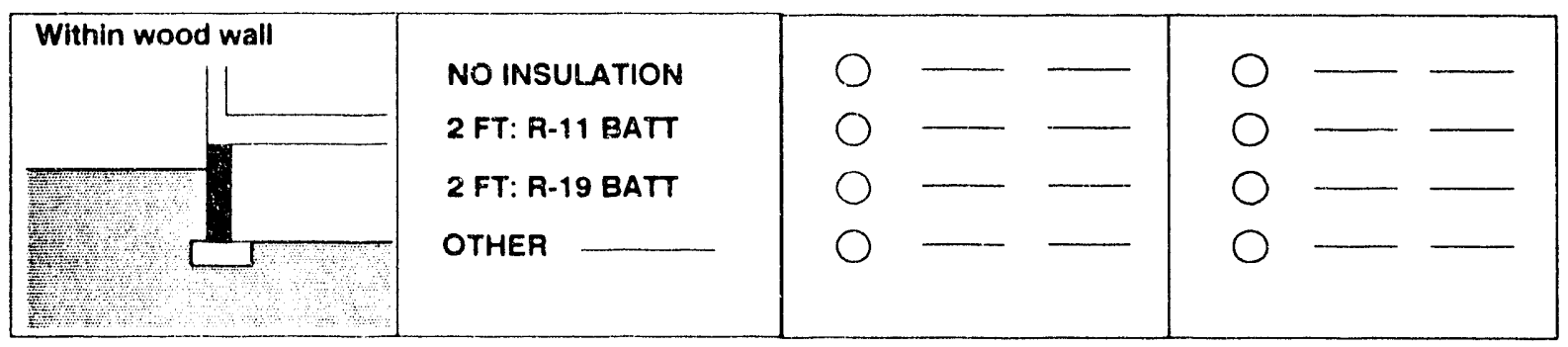

C: Vented crawl space - concrete or masonry foundation walls with ceiling Insulation

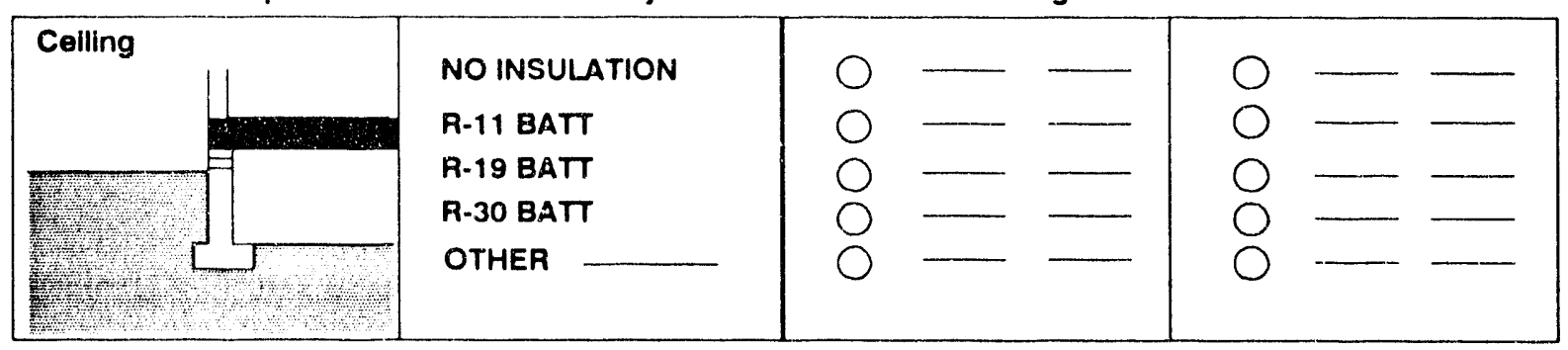


Table A.4. How are you or others in your area insulating - Slab-on-Grade Foundations?

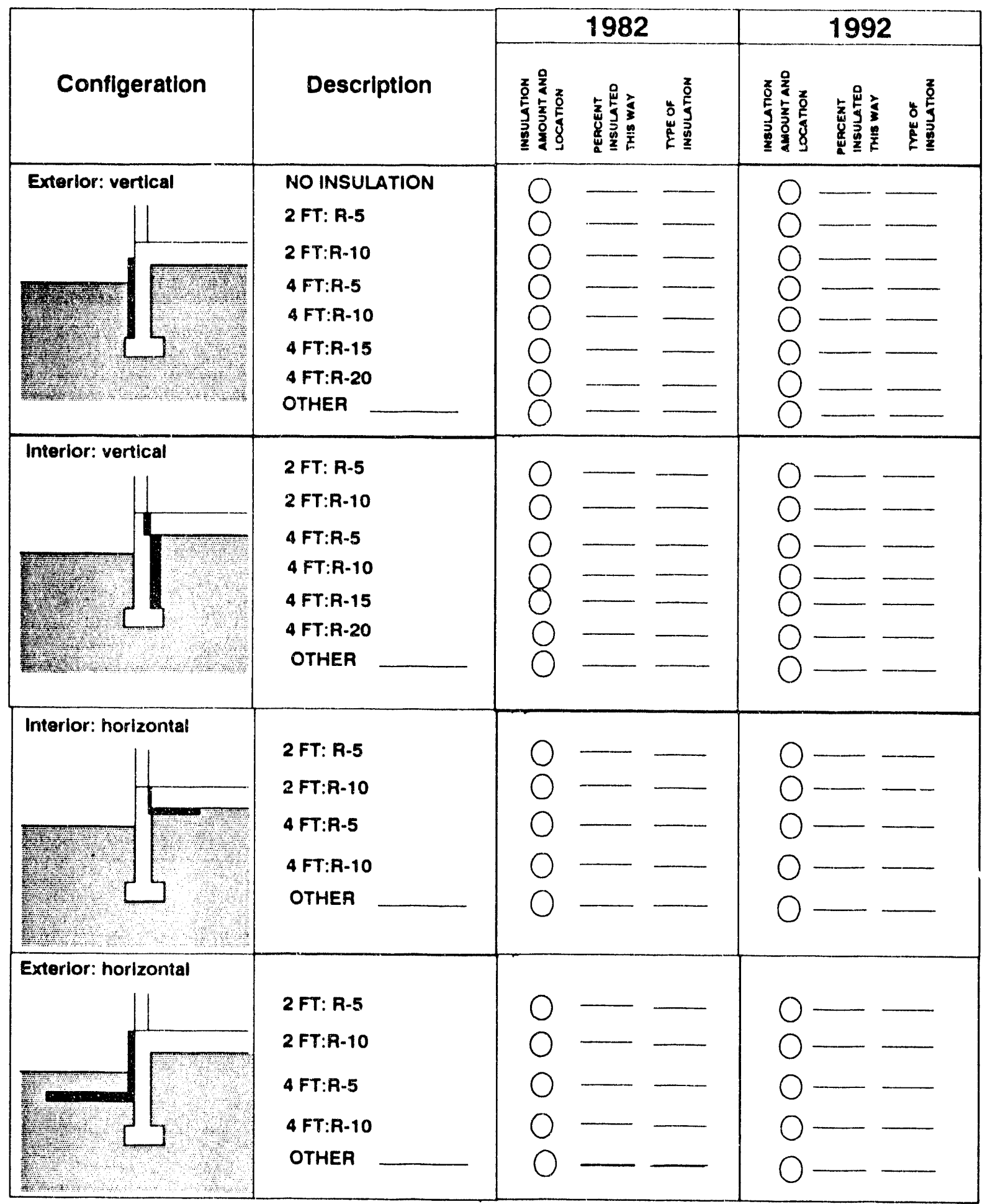




\section{APPENDIX B}



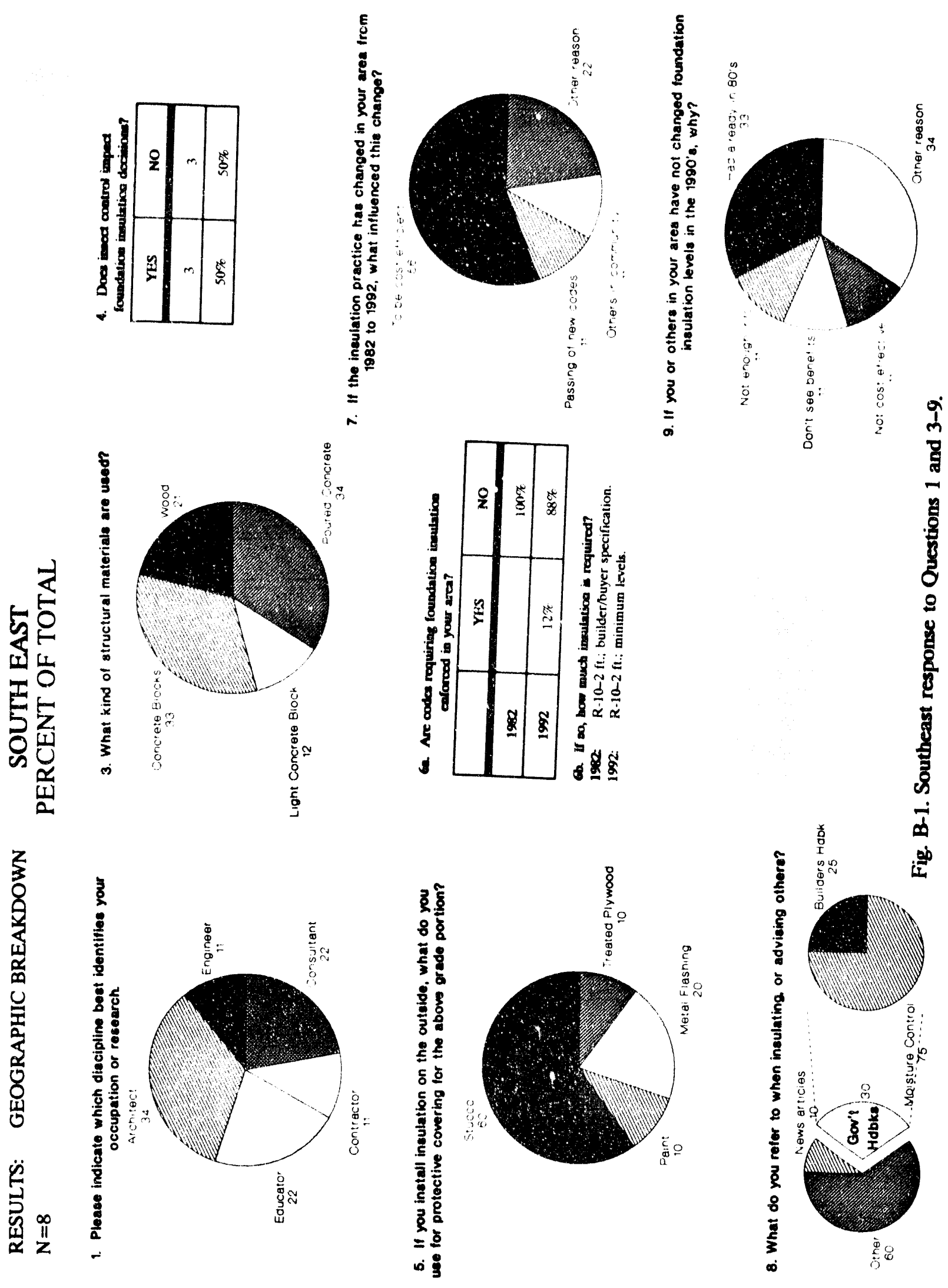


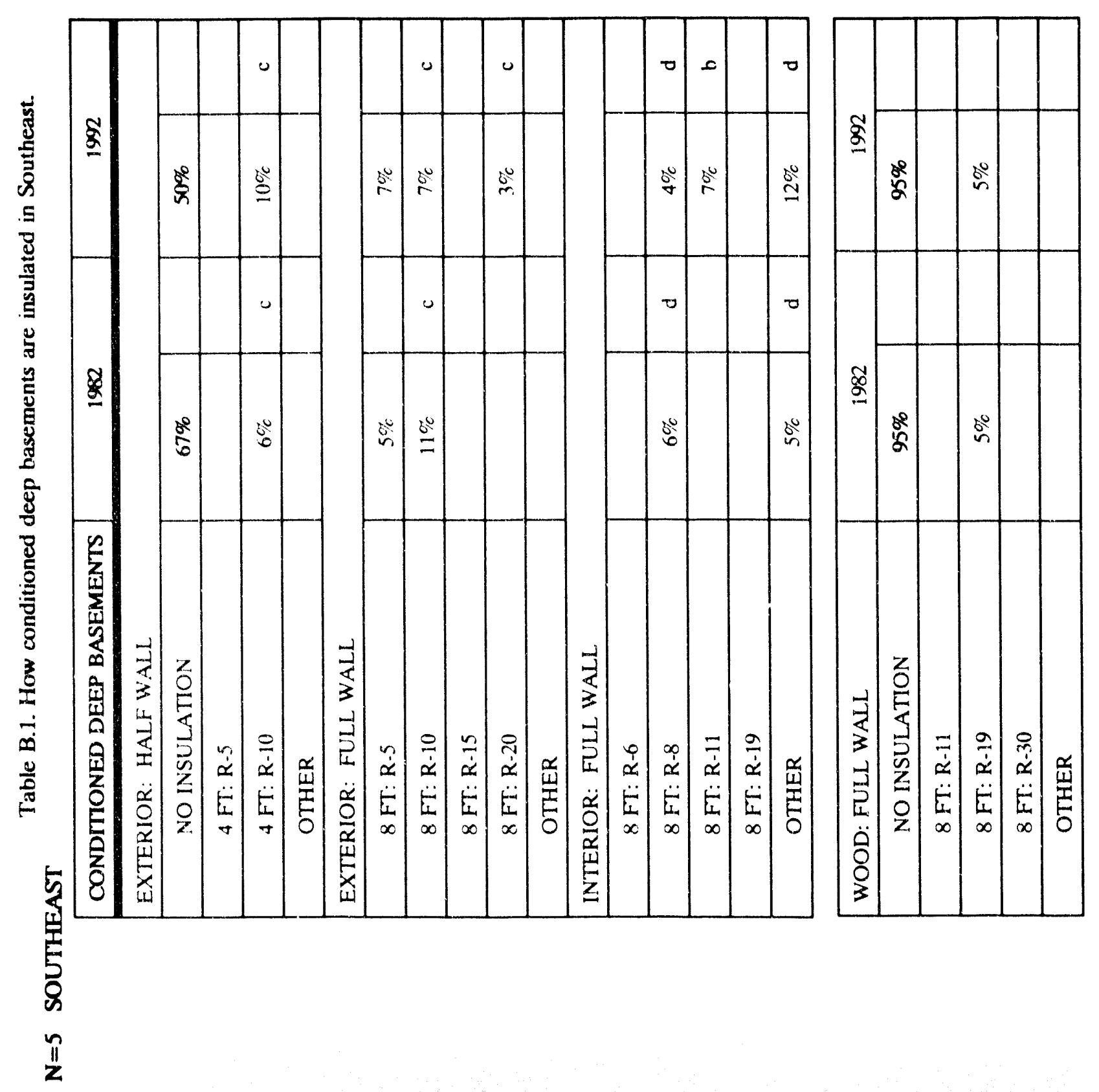




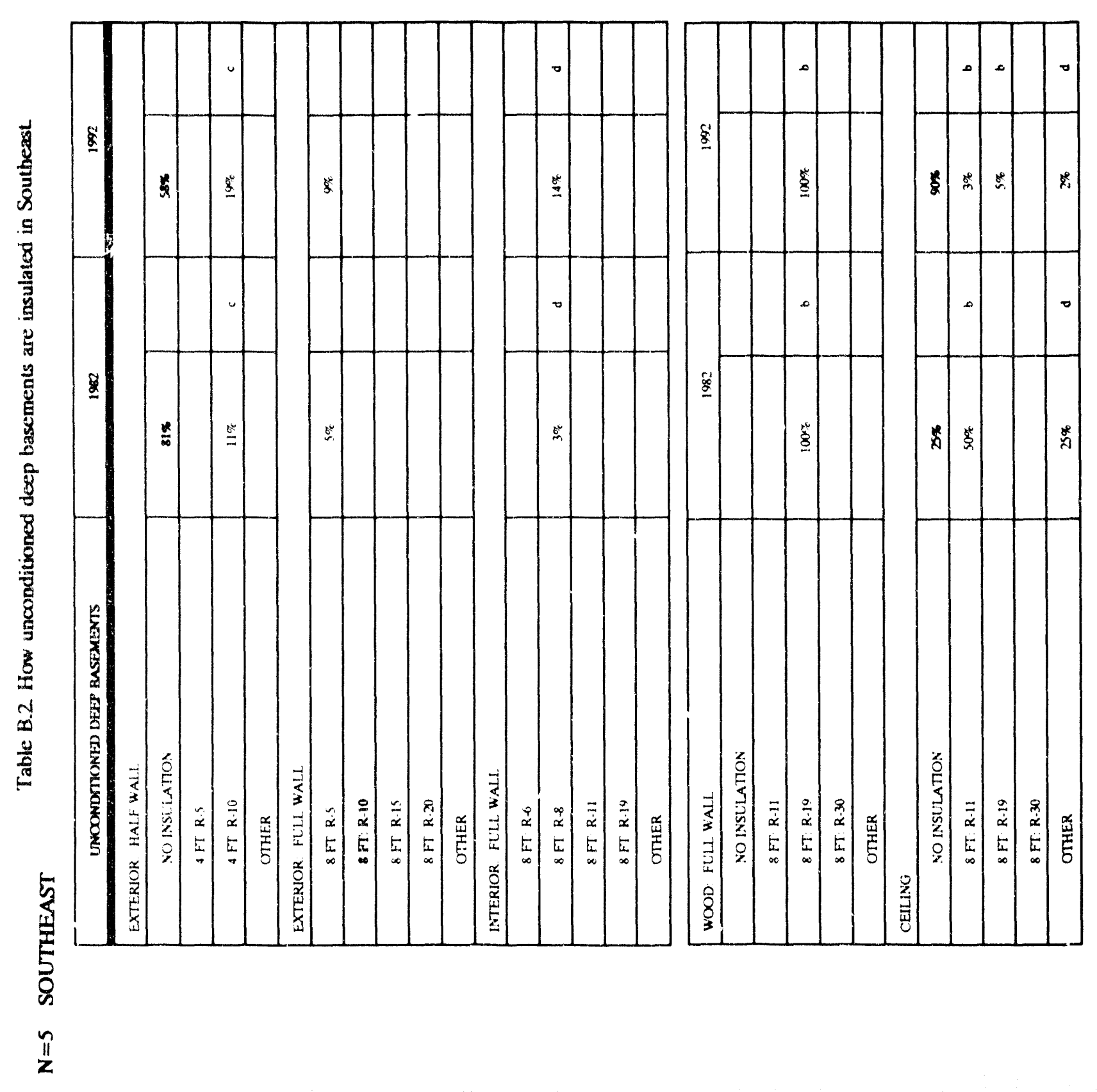




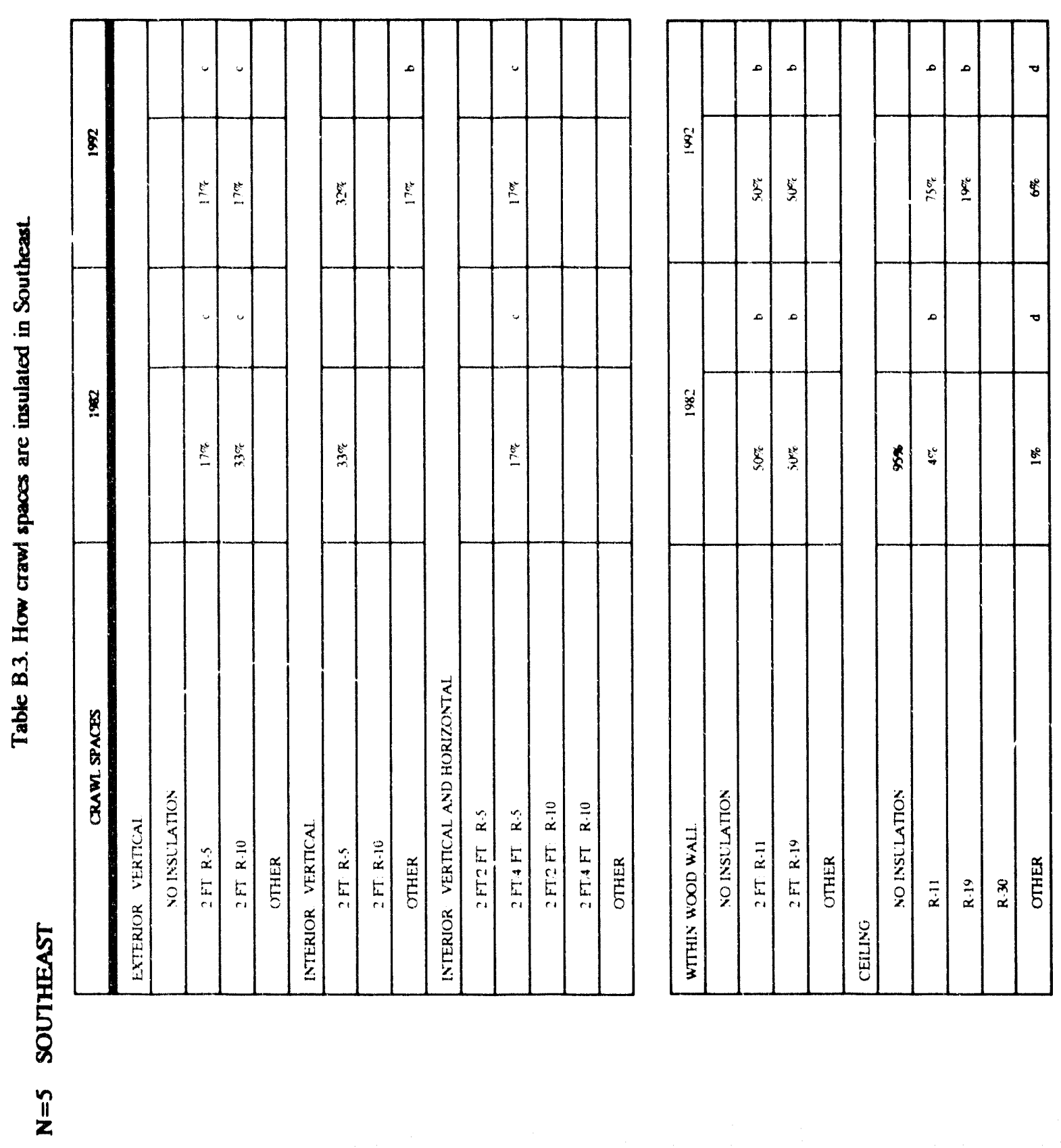




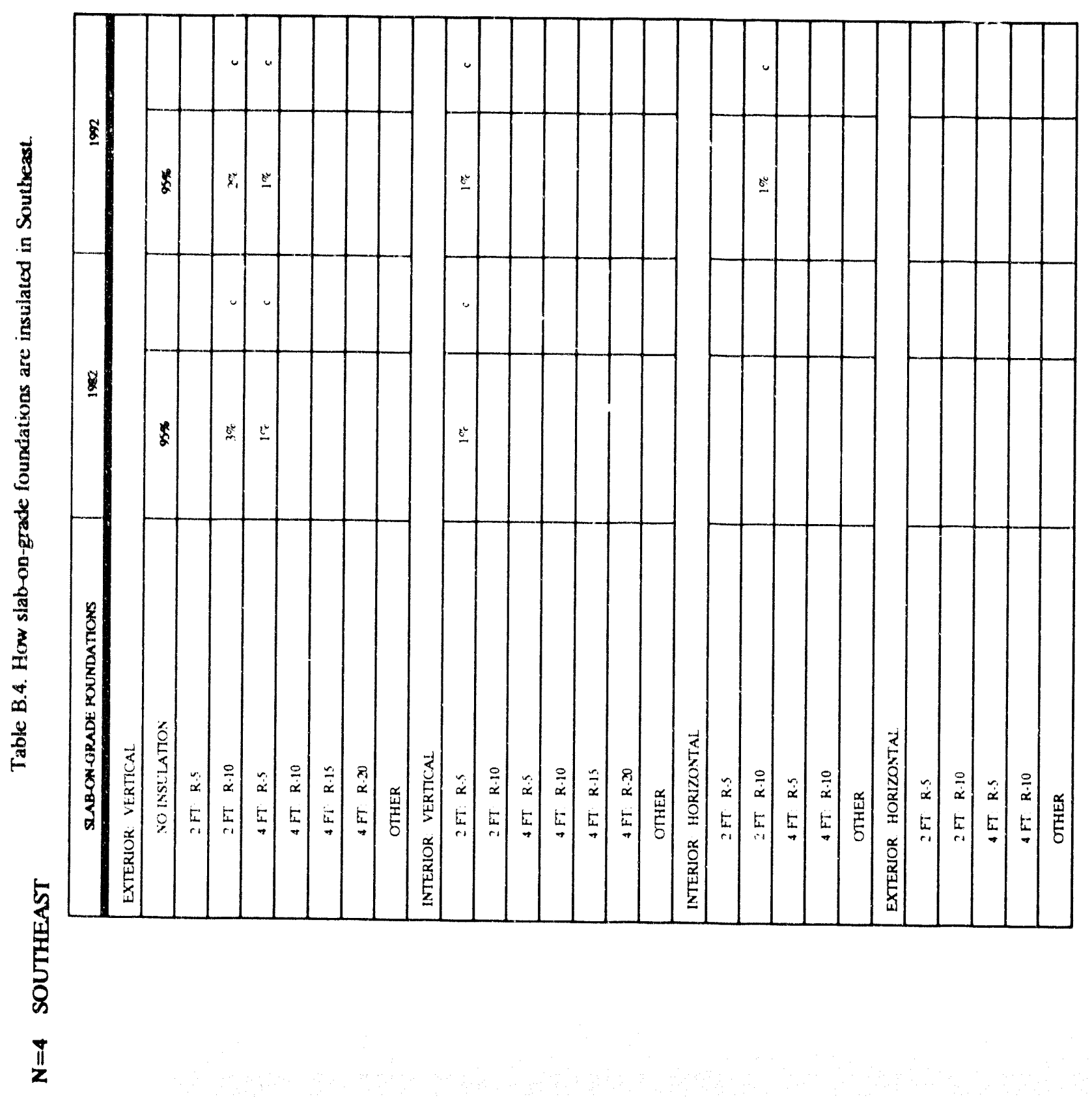




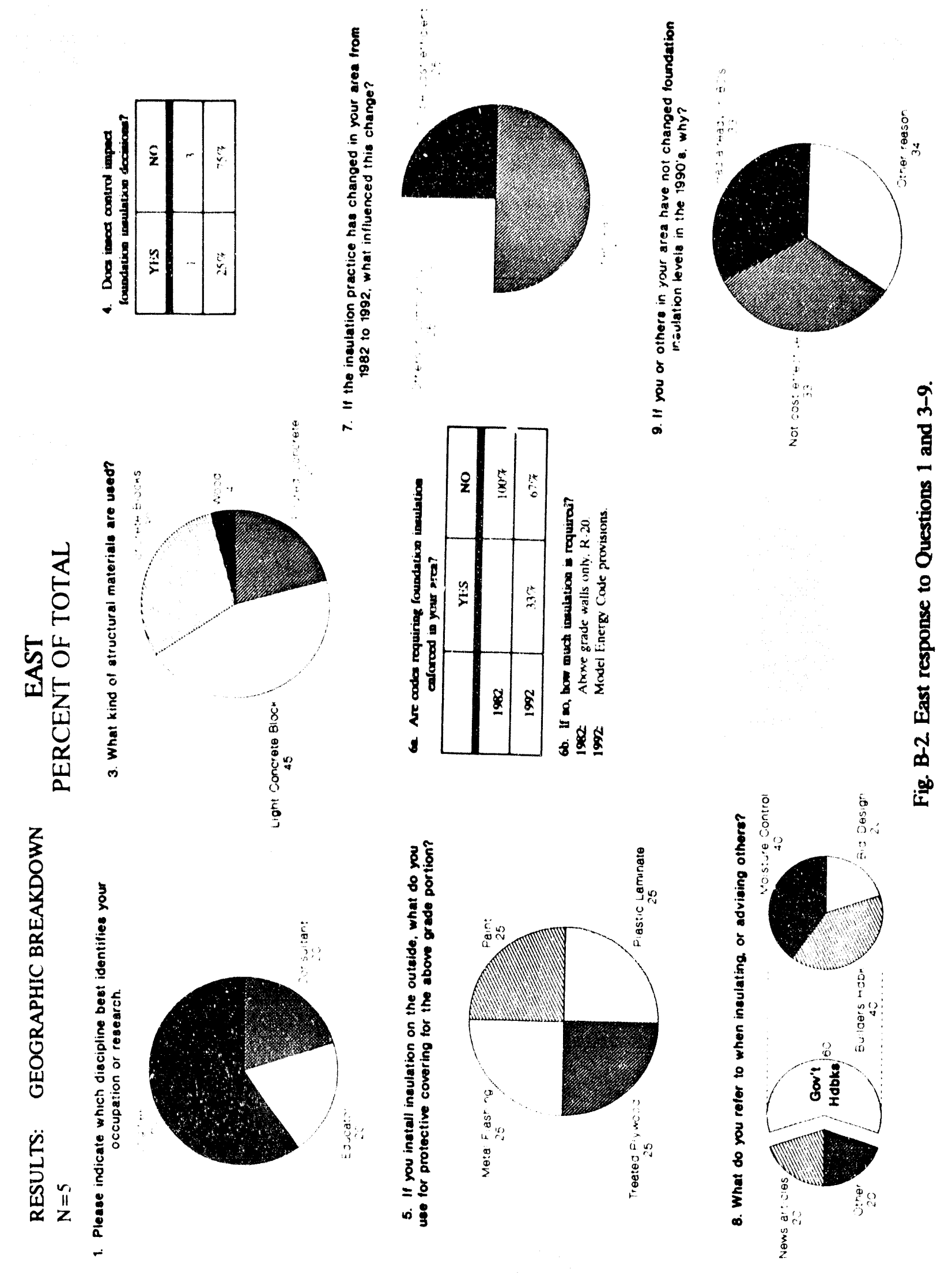




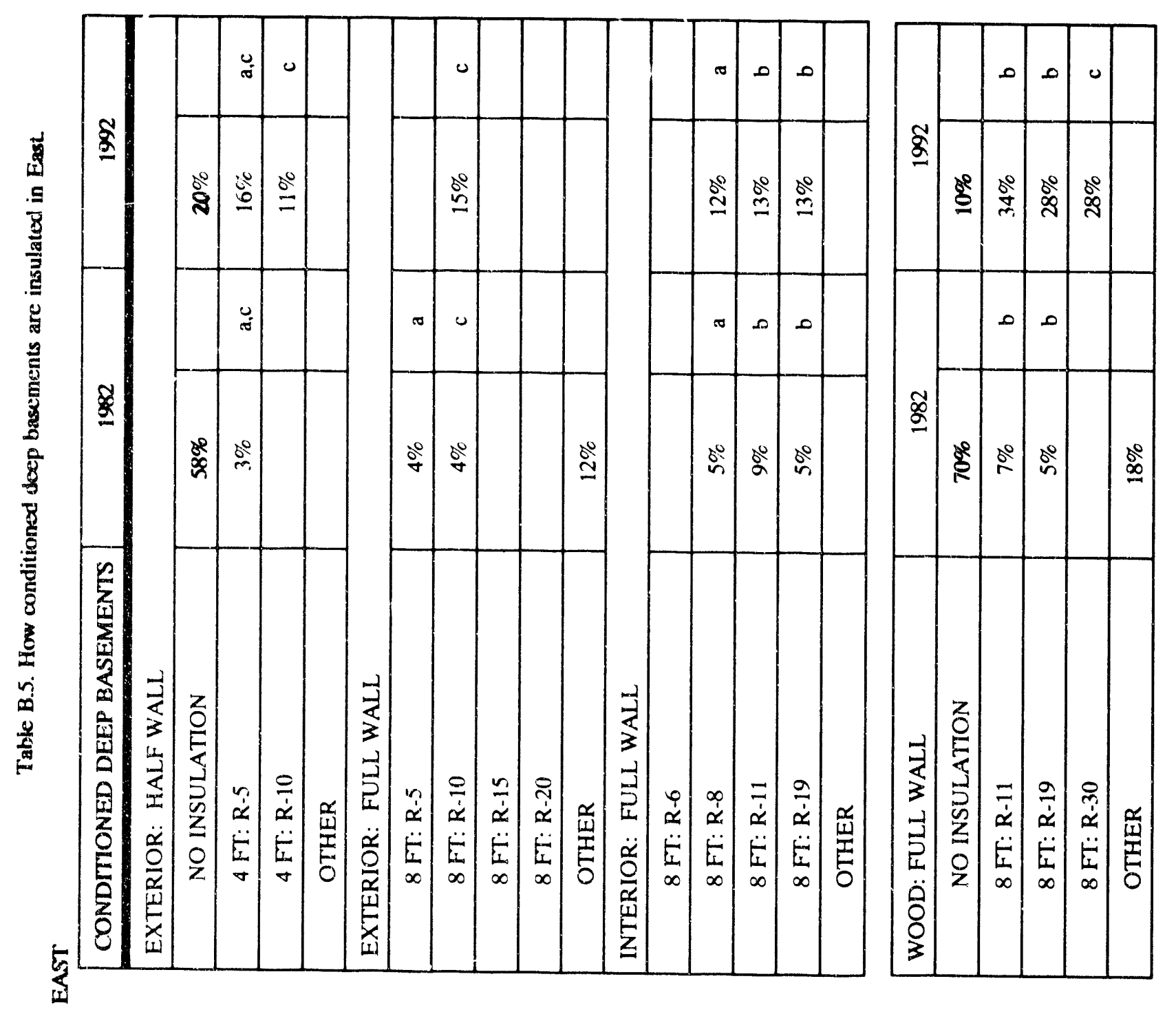

II 


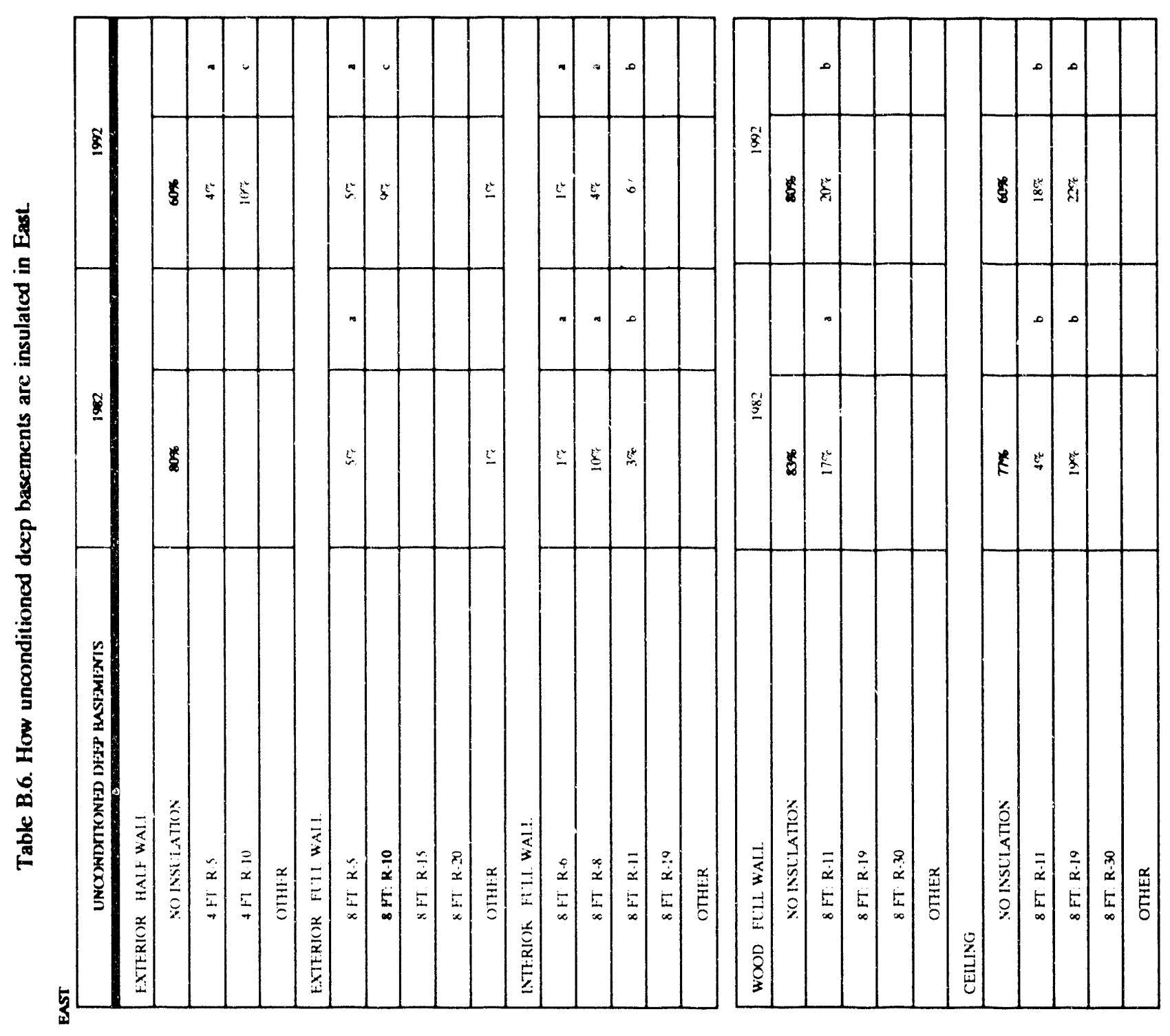




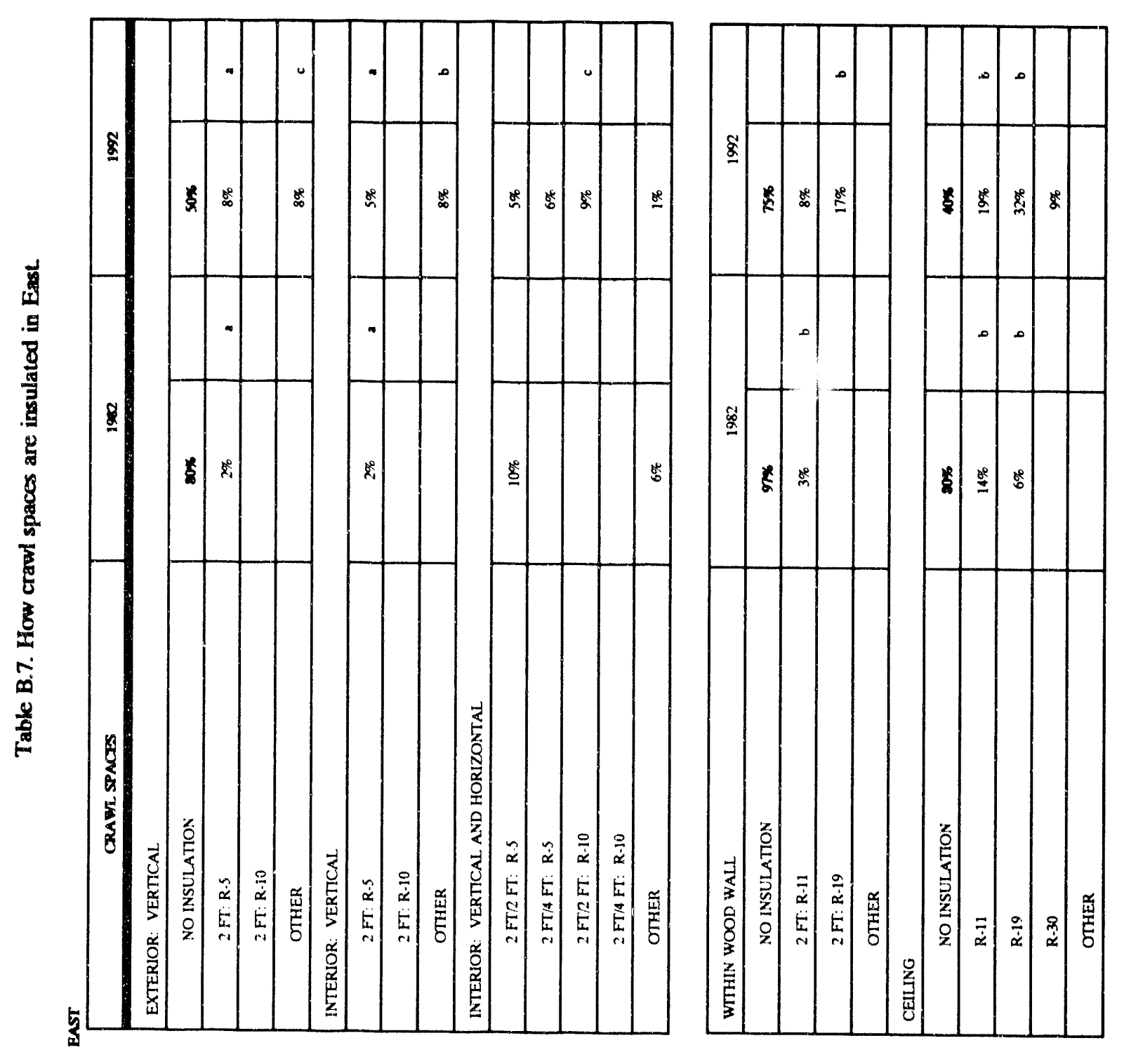

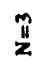




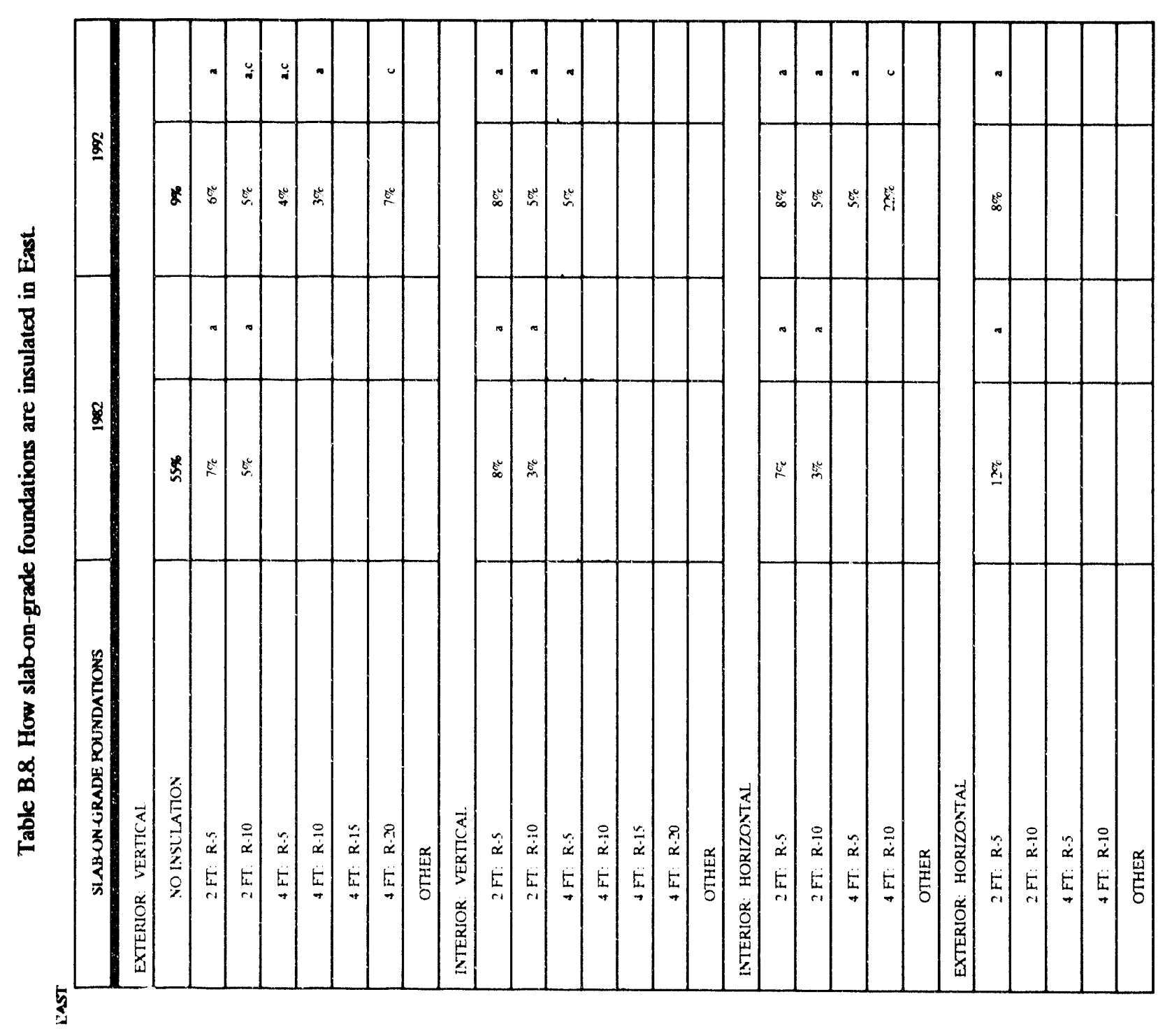




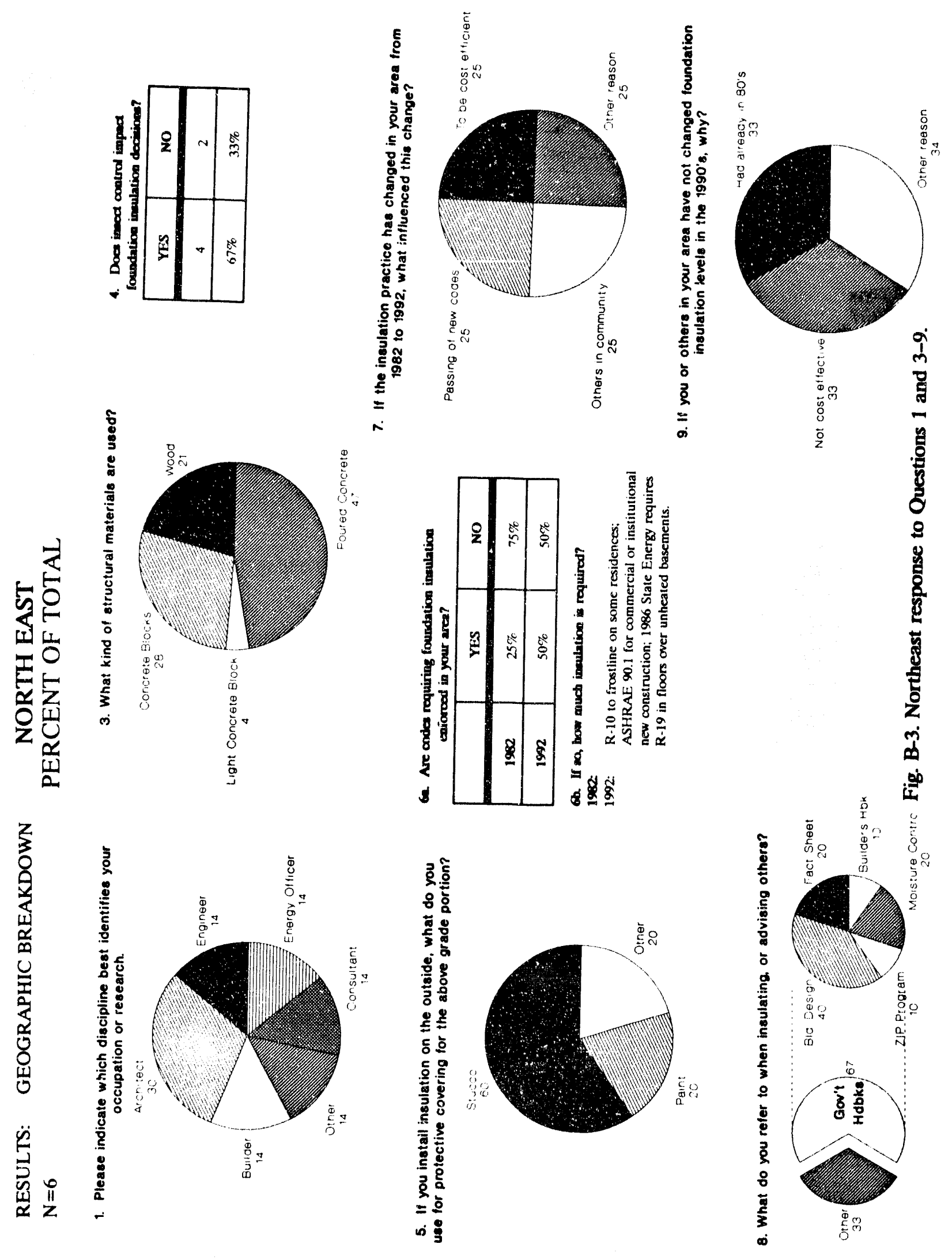




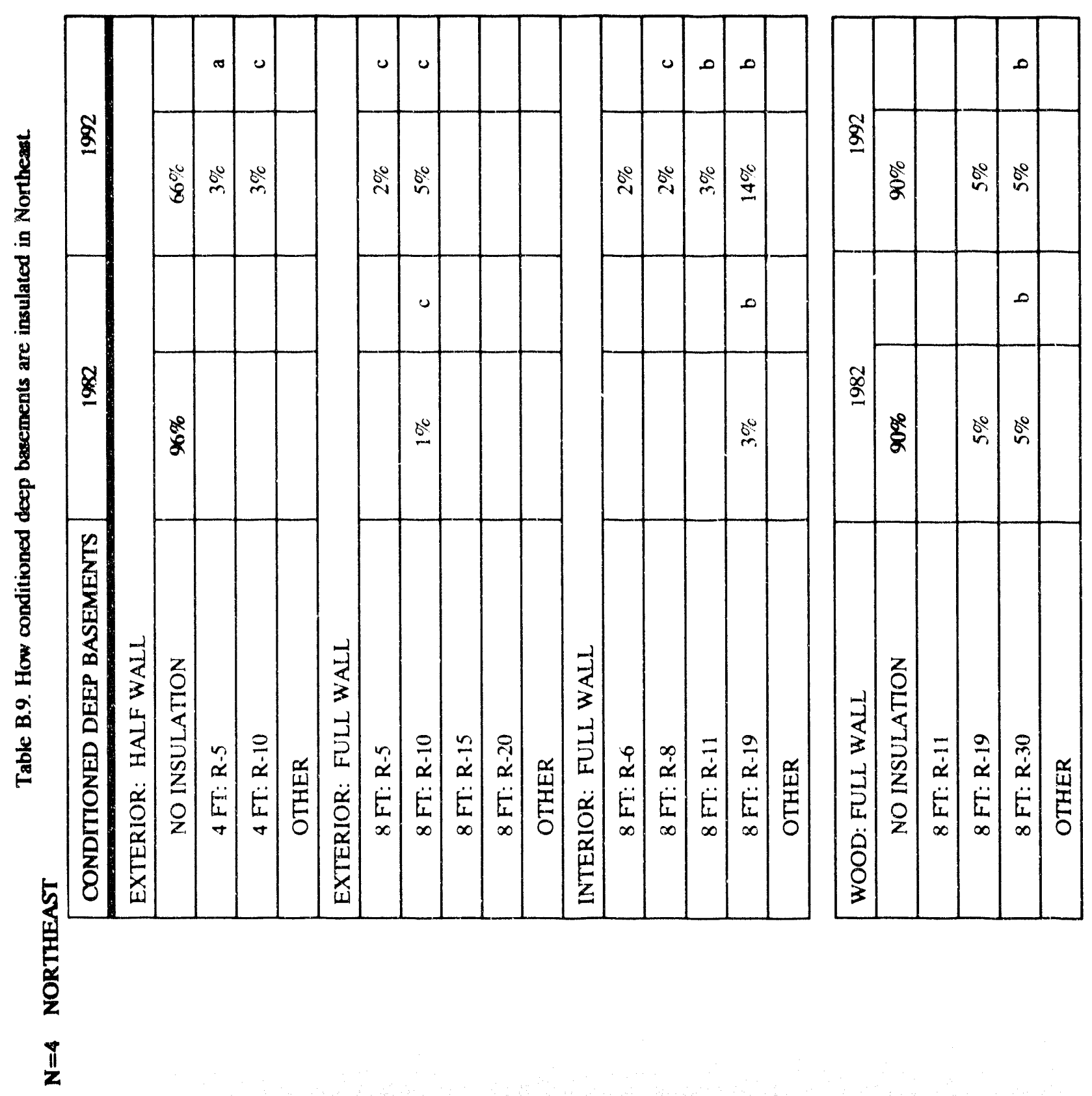




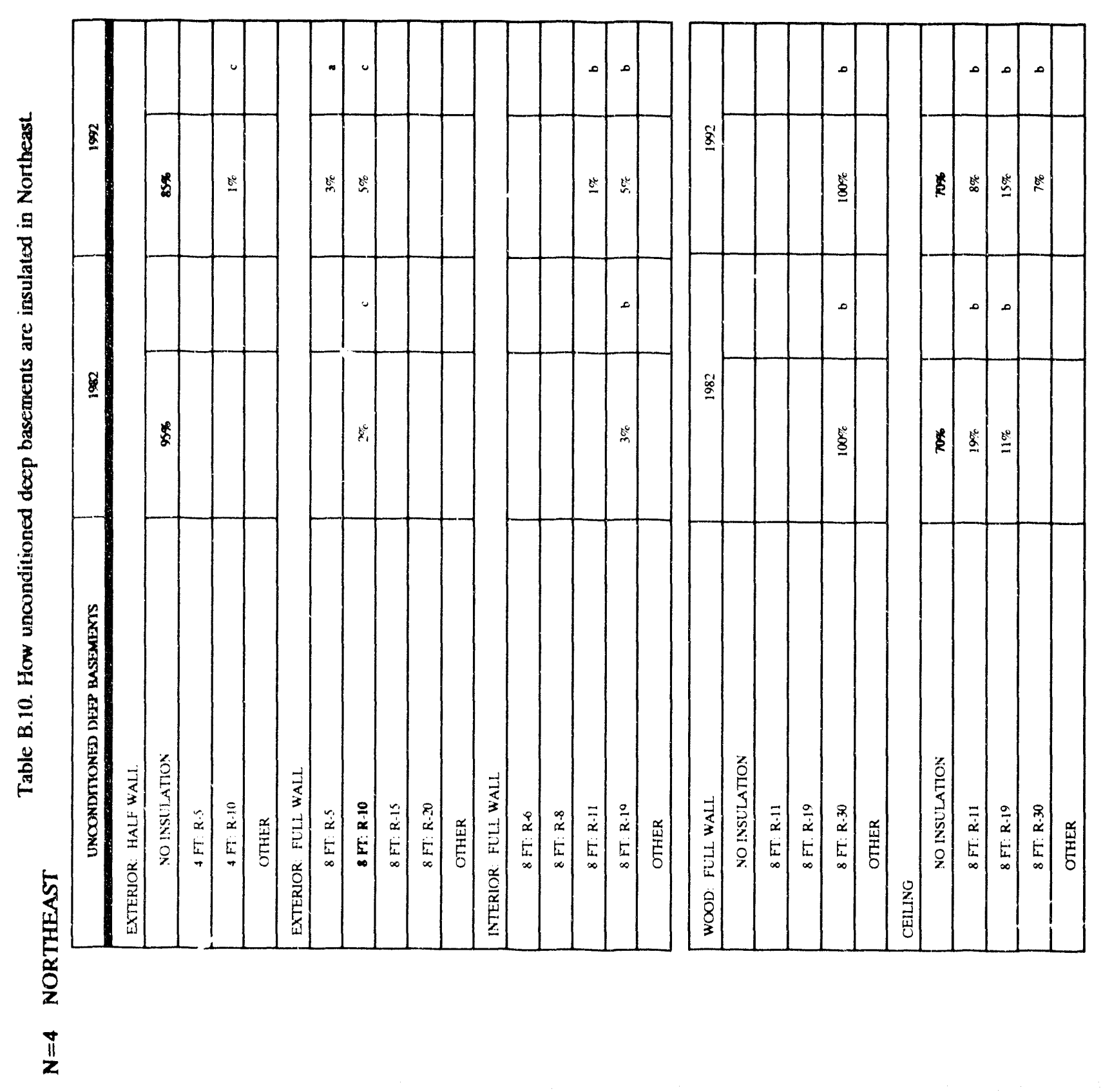




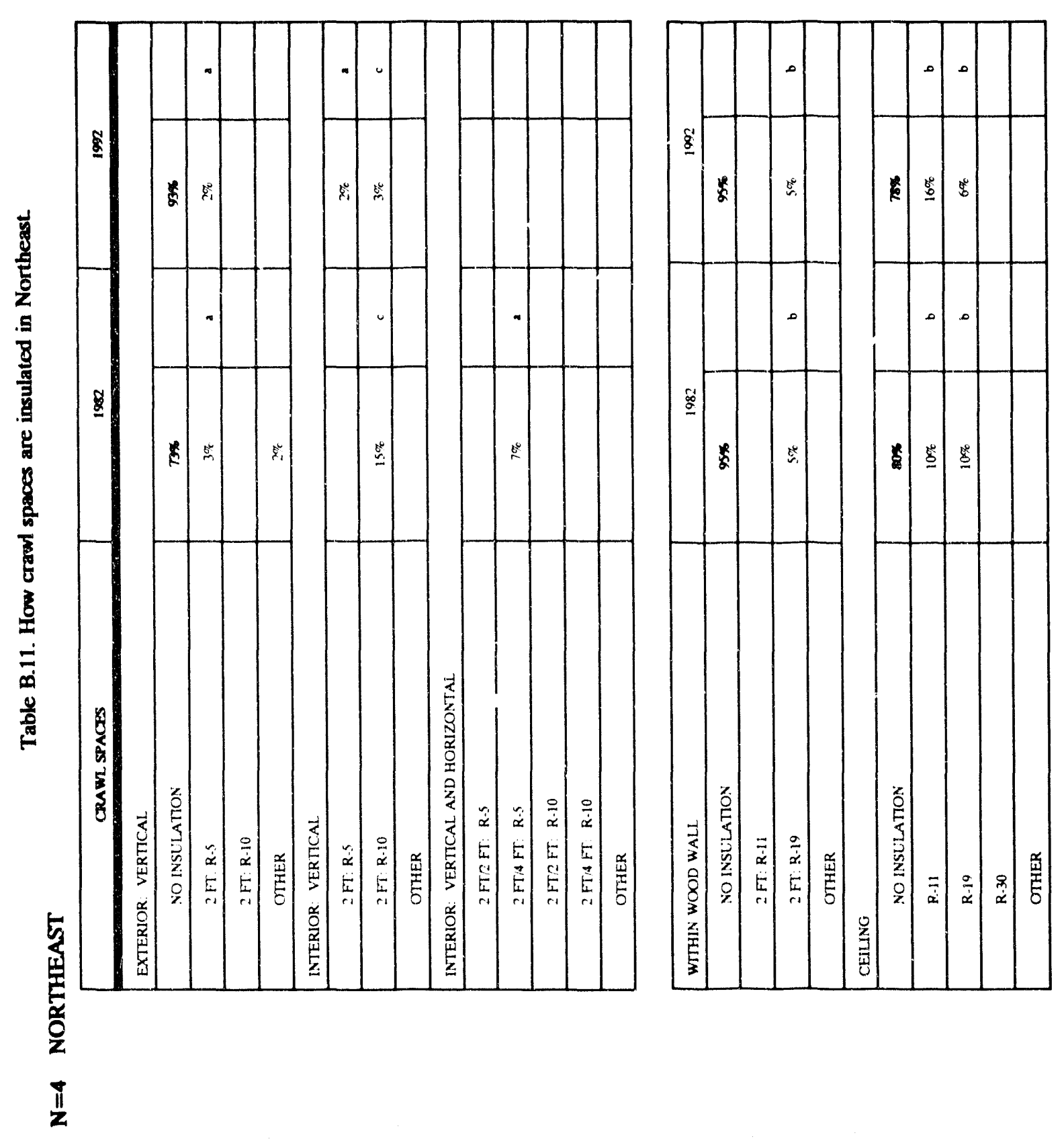




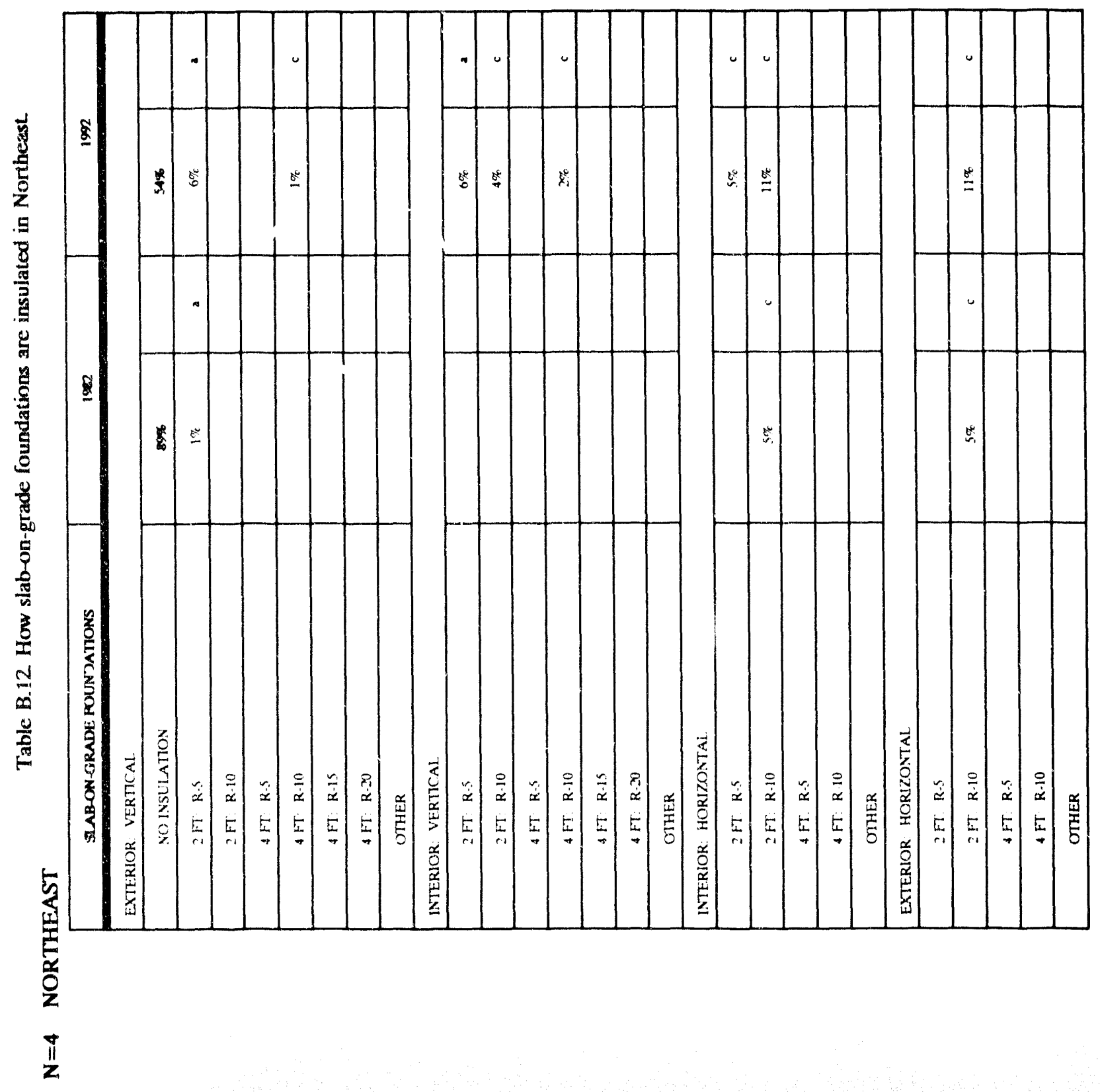




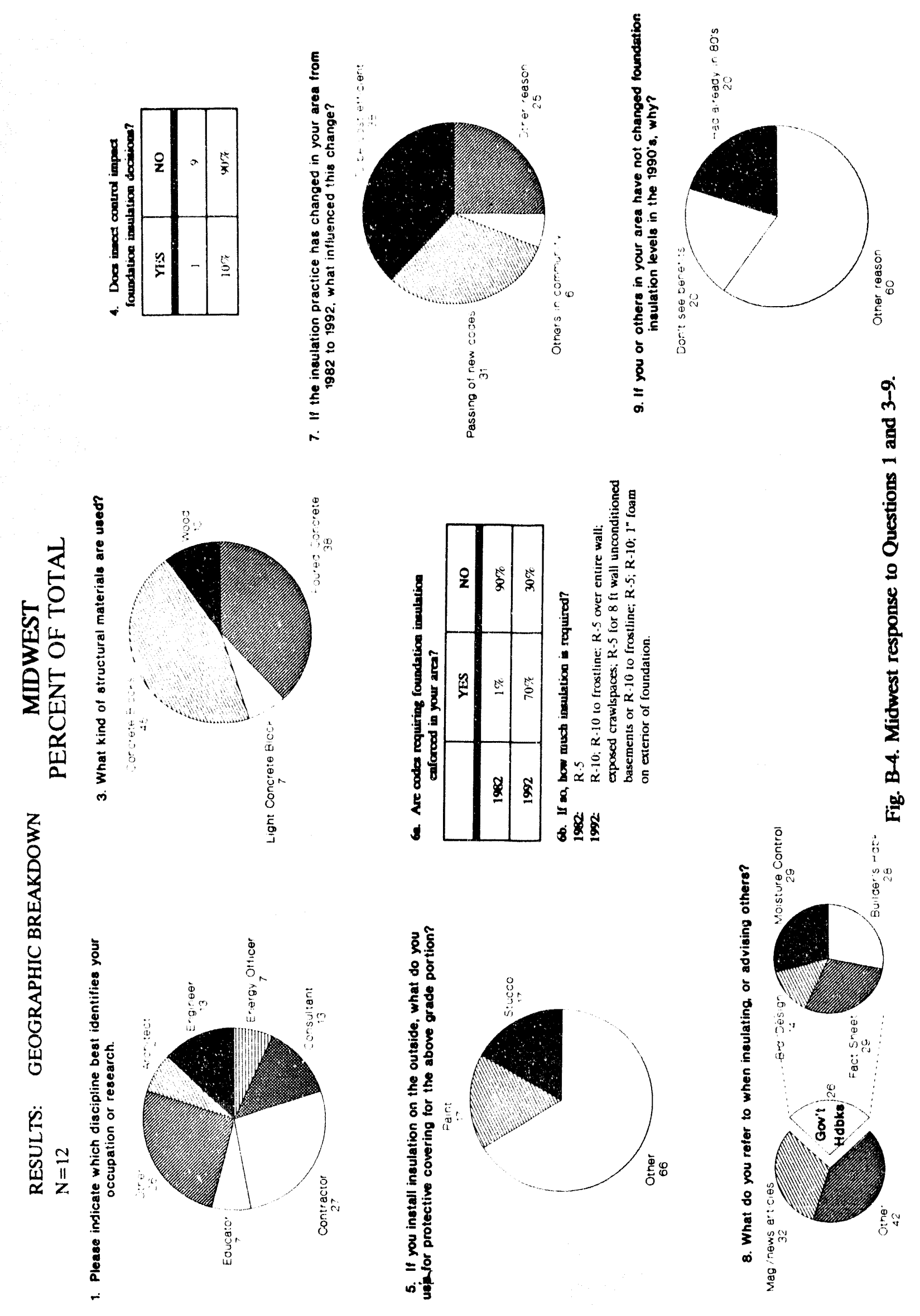




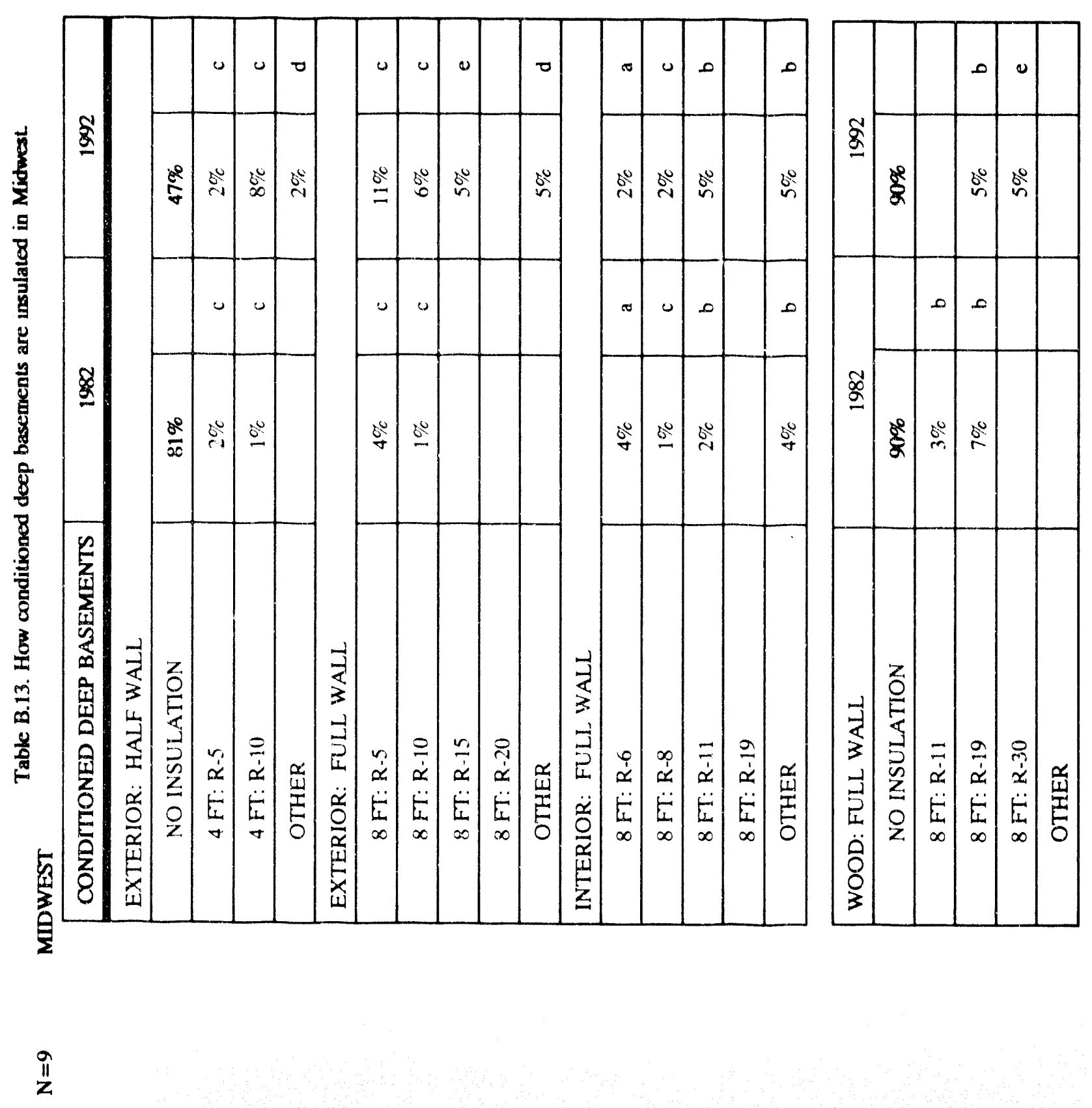




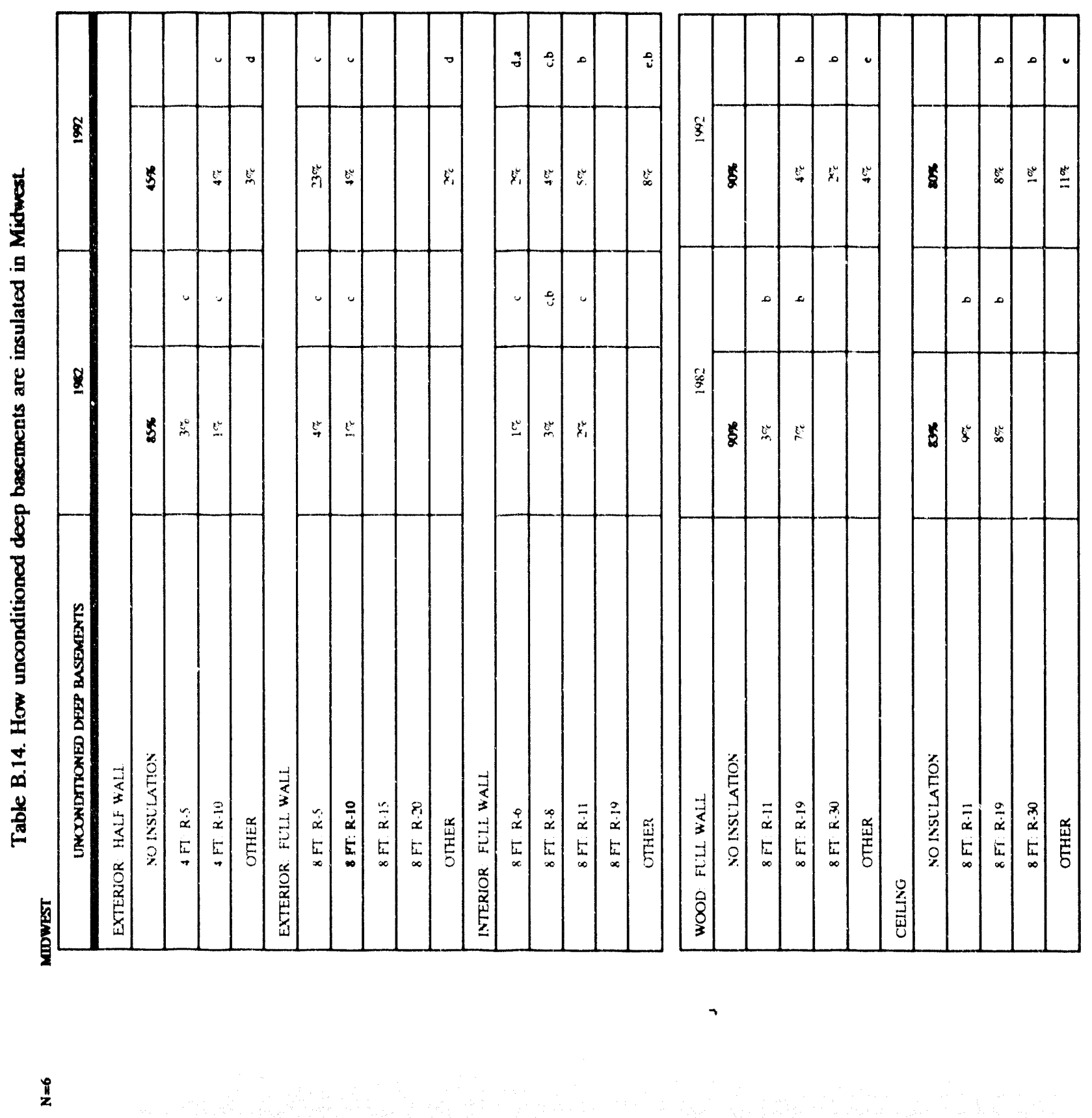




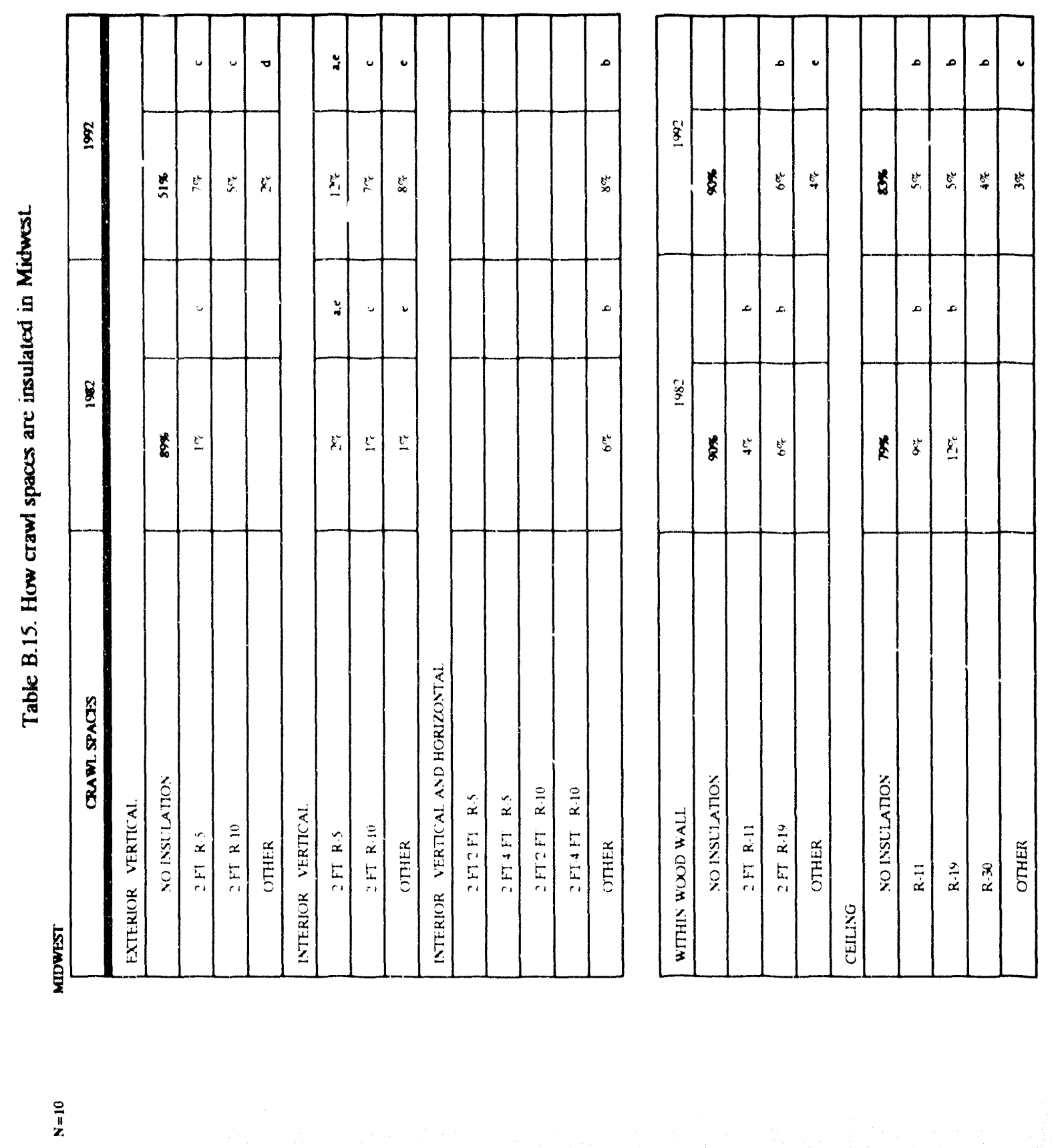




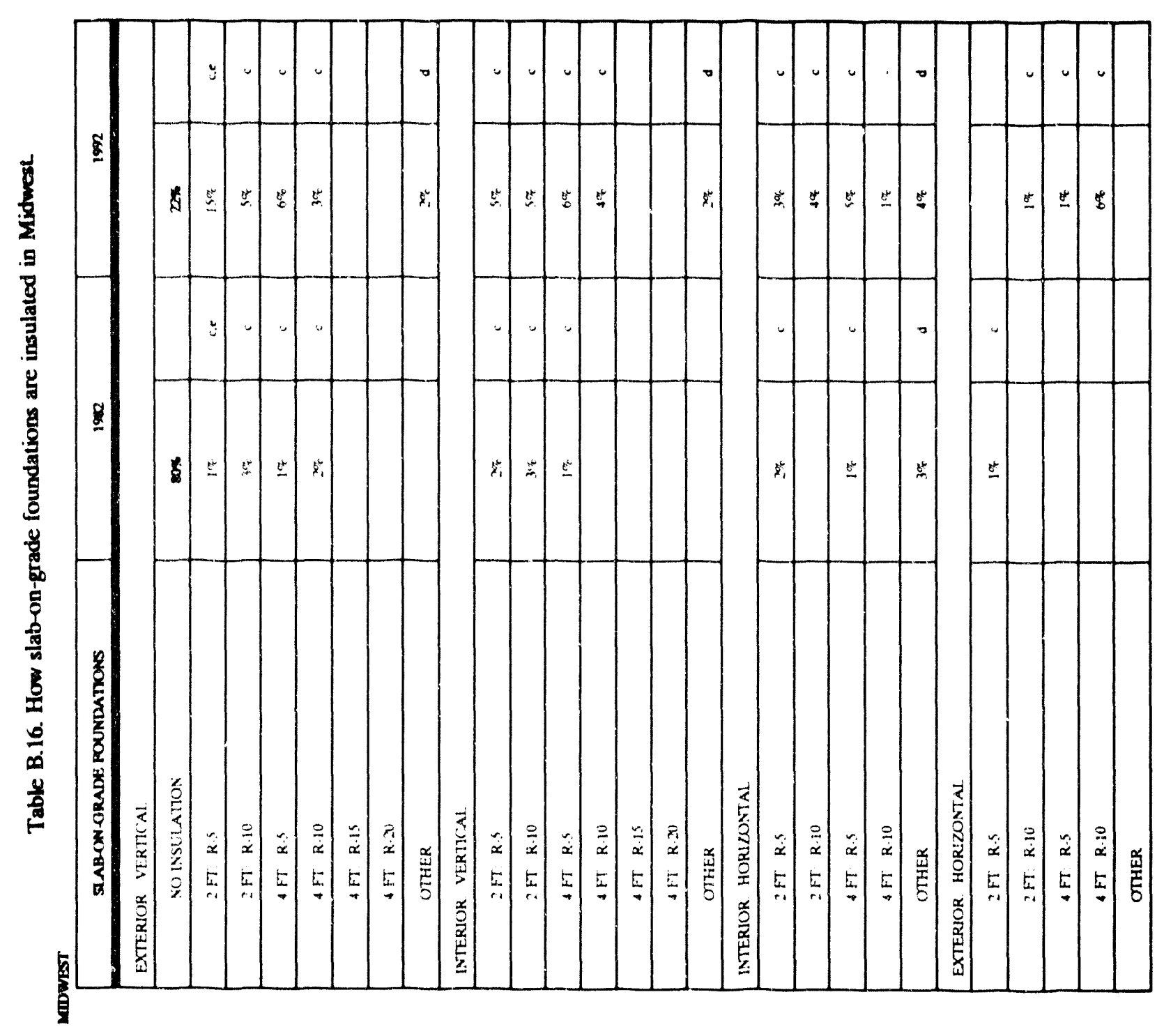

$\frac{\pi}{2}$ 


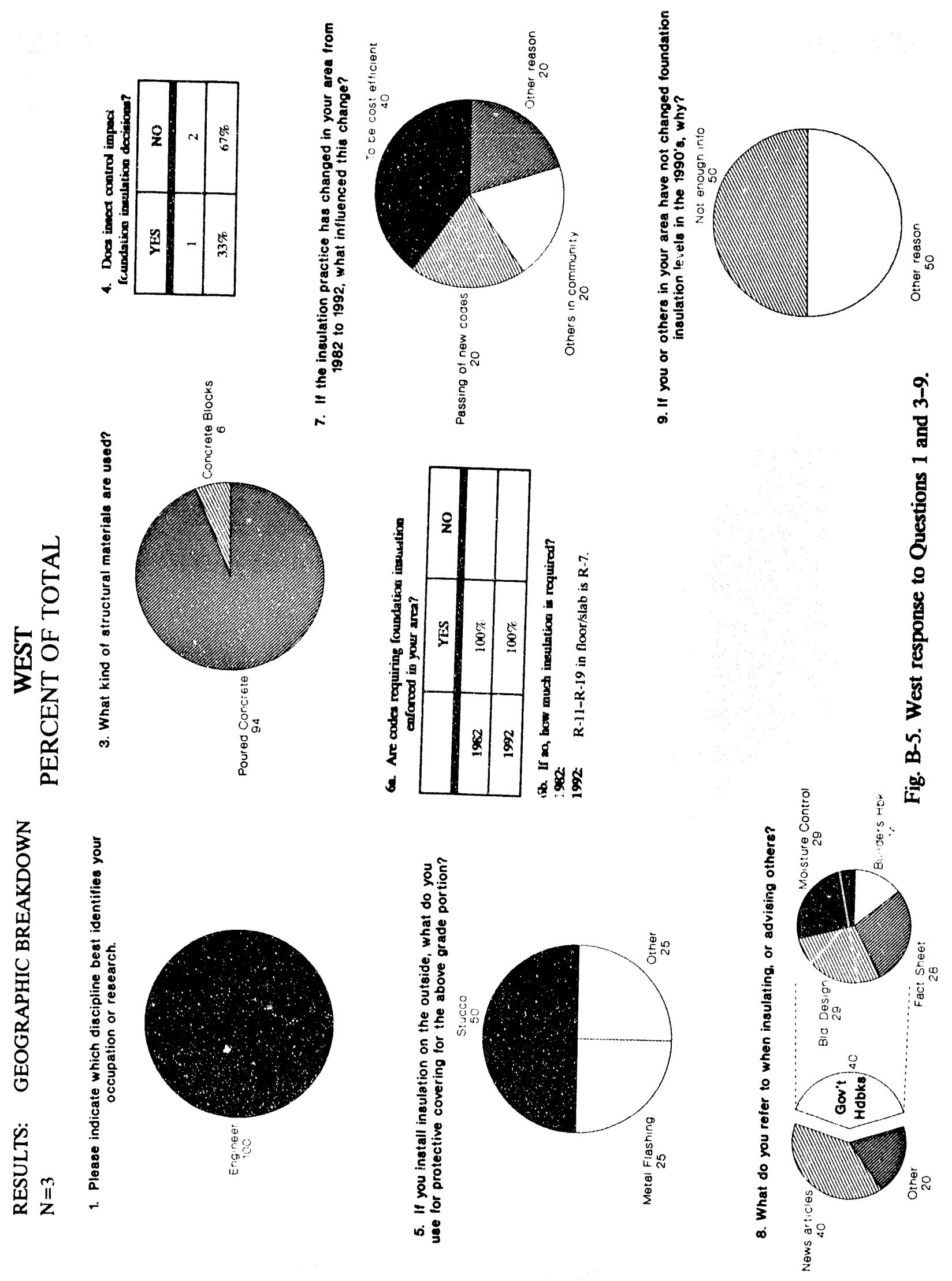




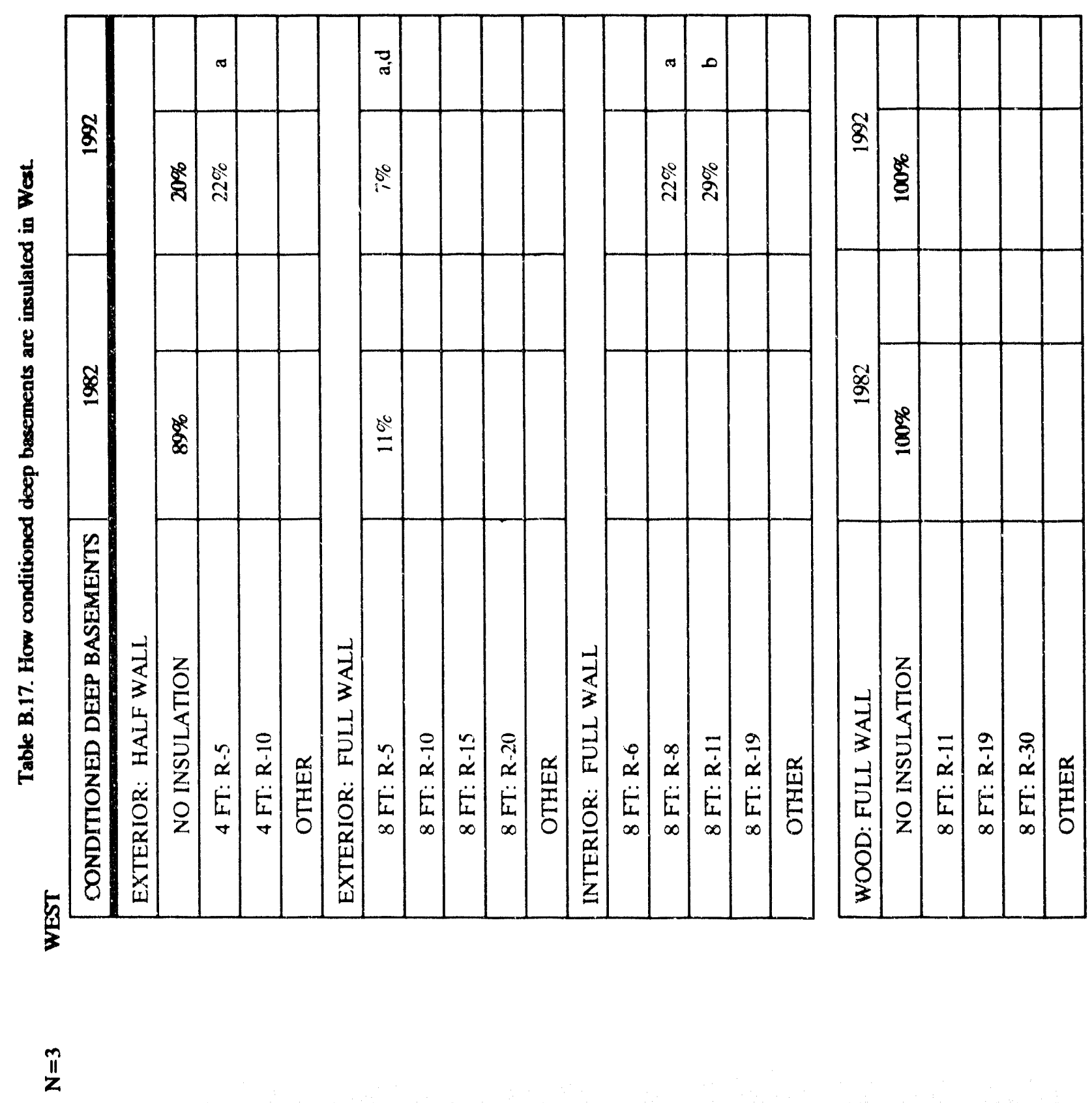




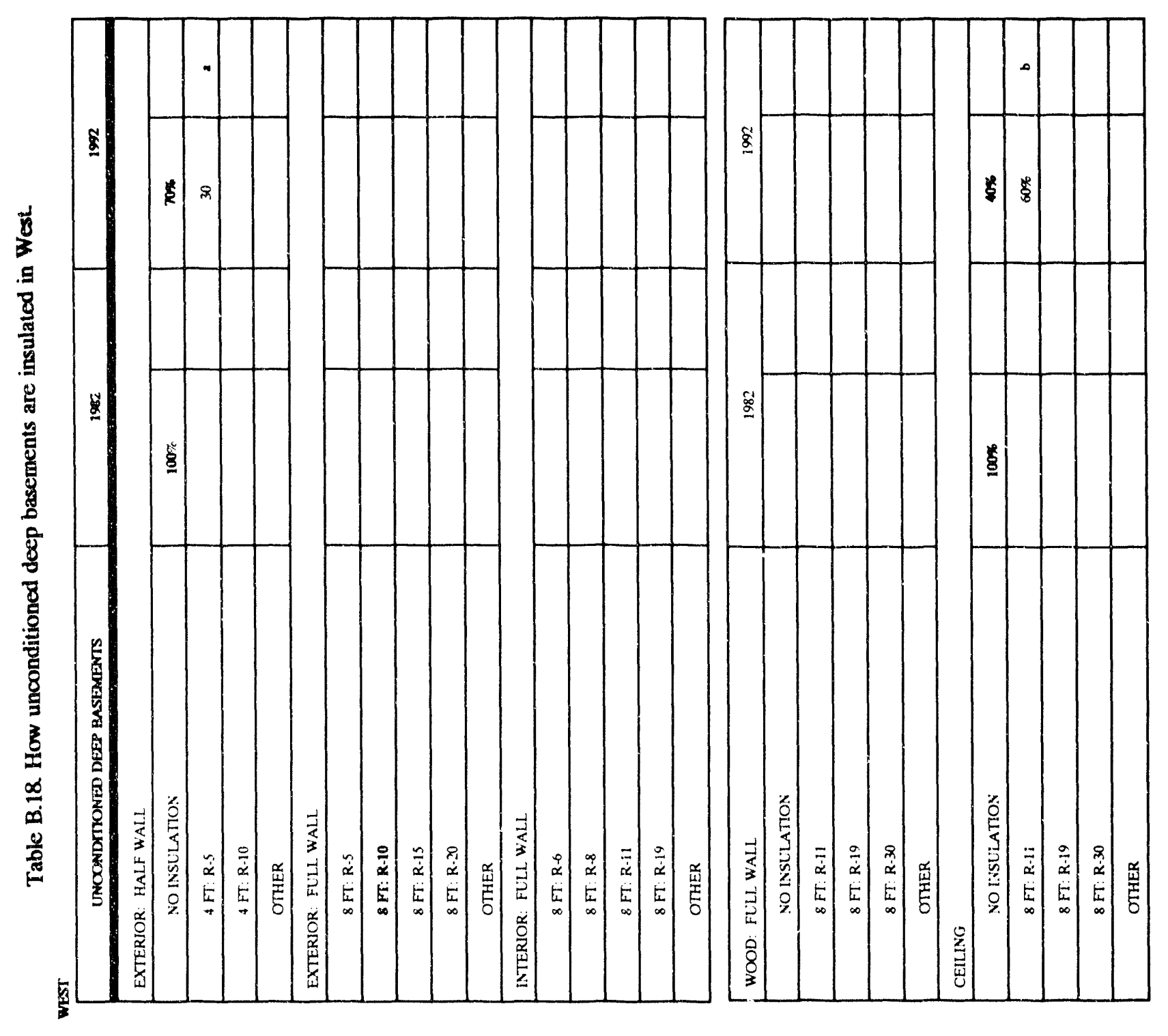

in 


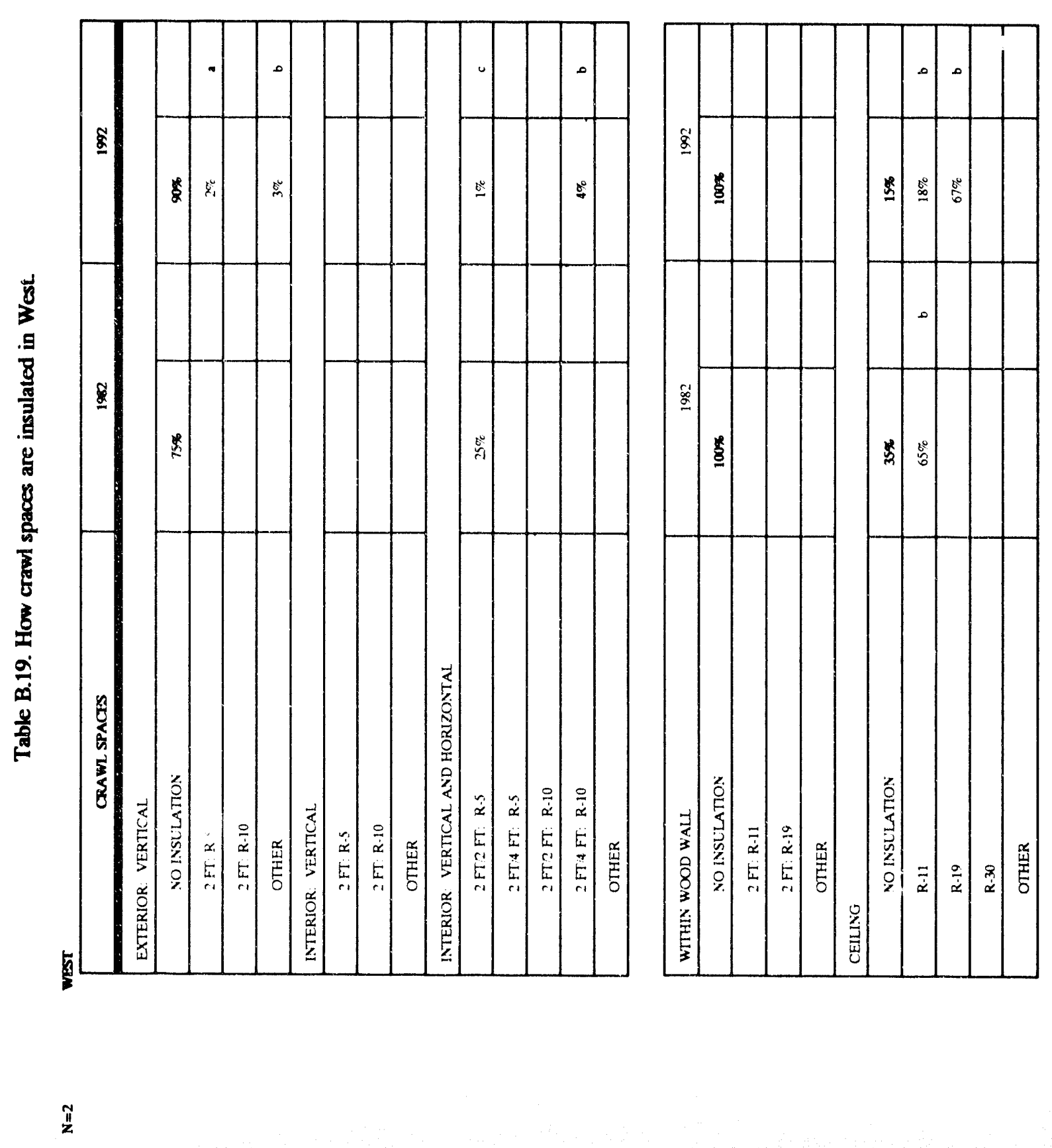




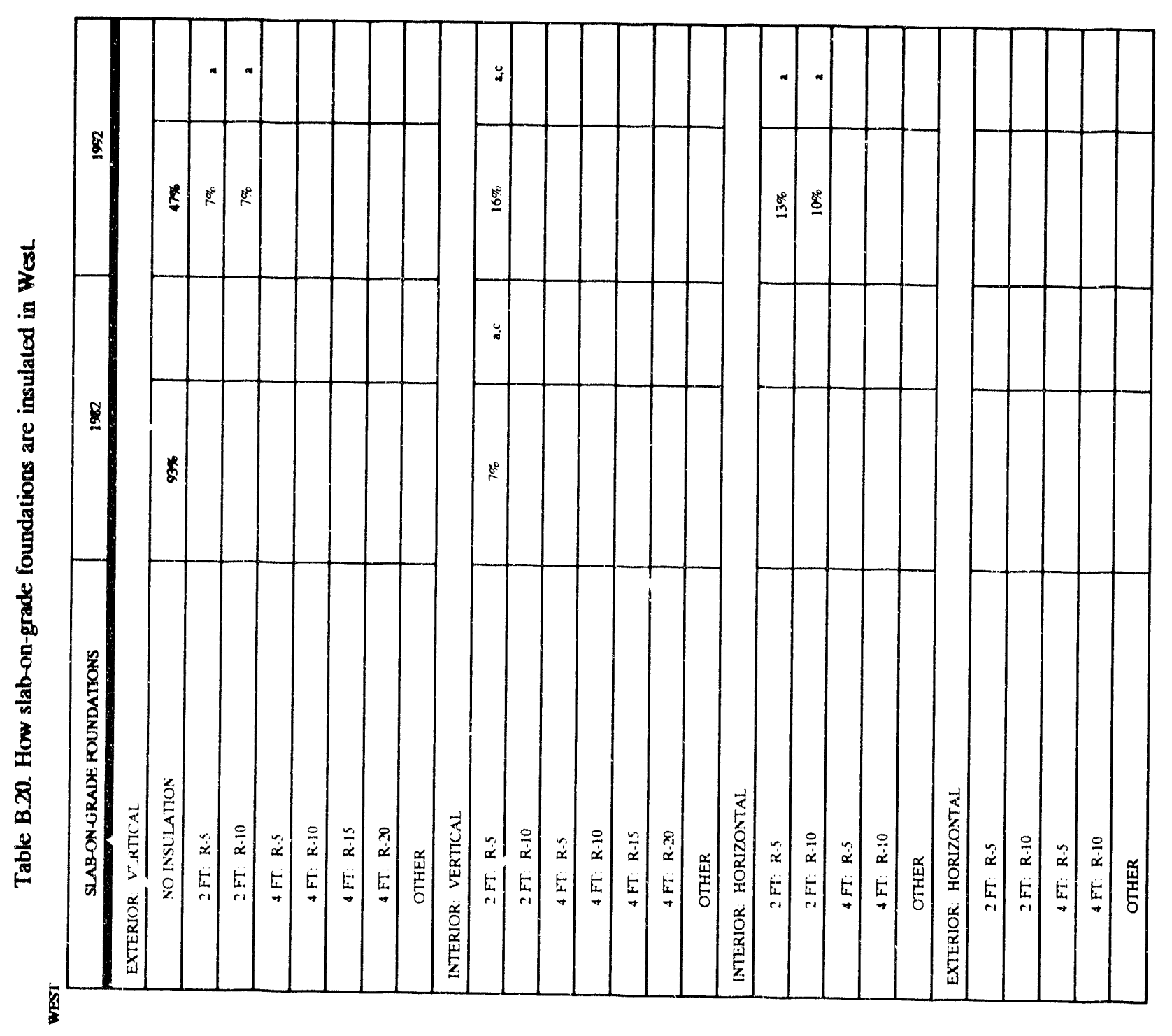

$\frac{\pi}{2}$ 

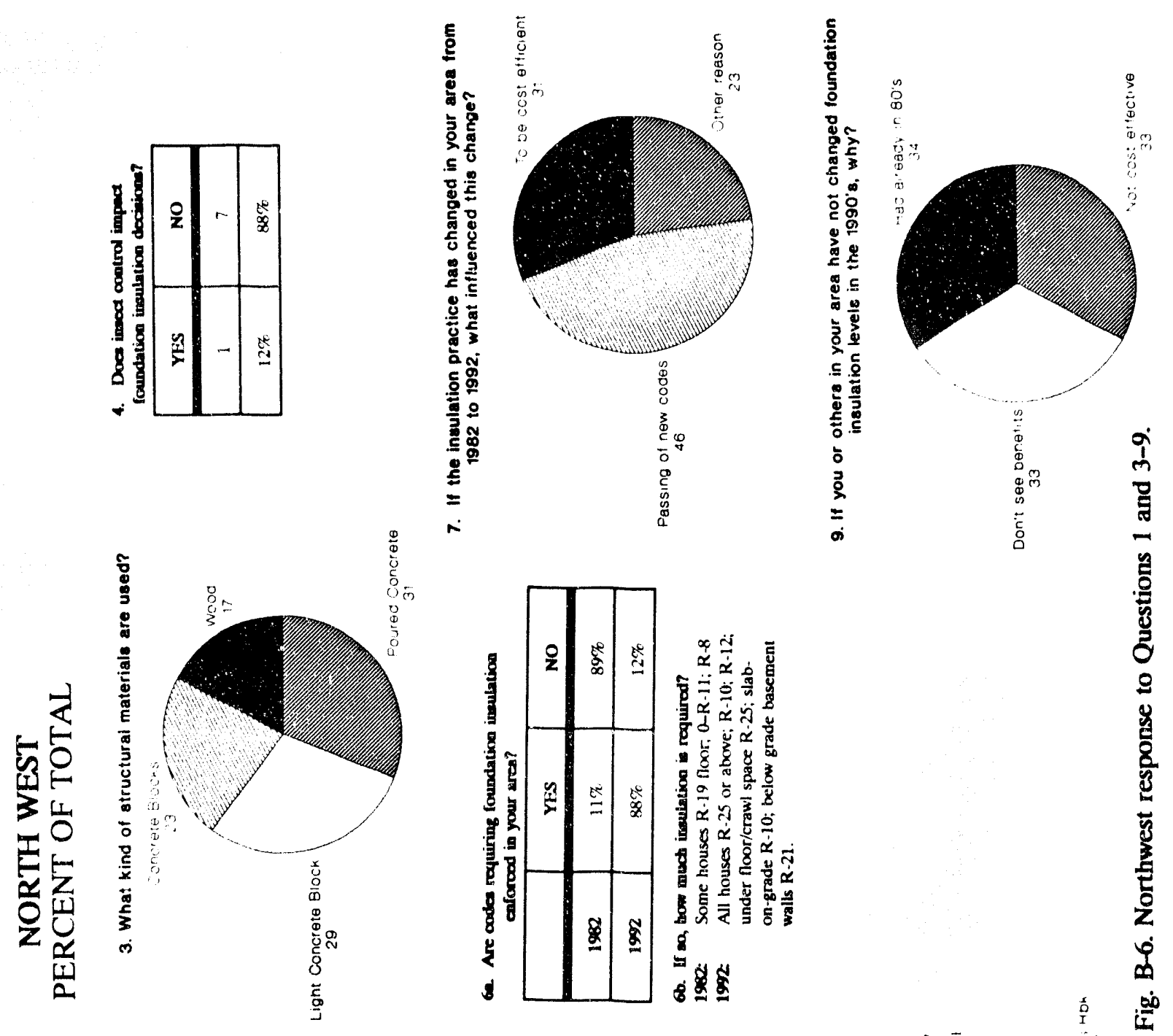

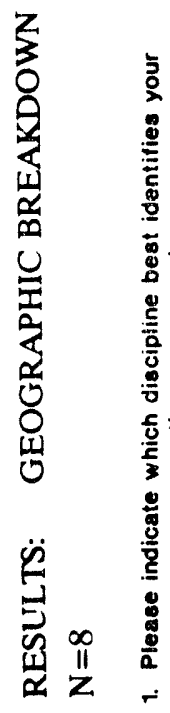
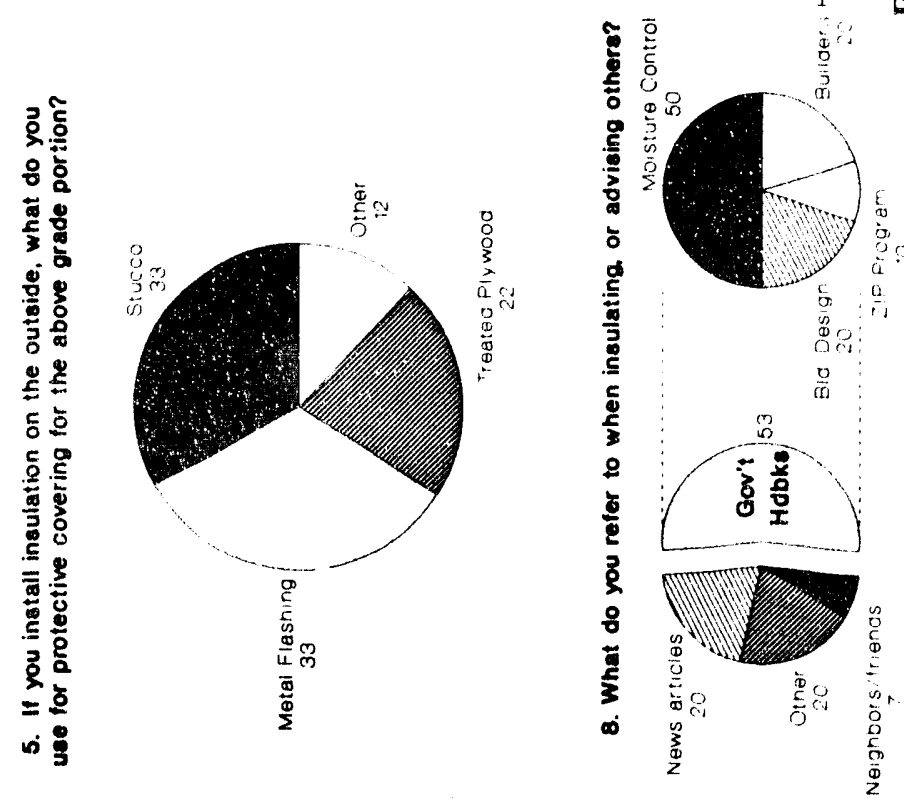


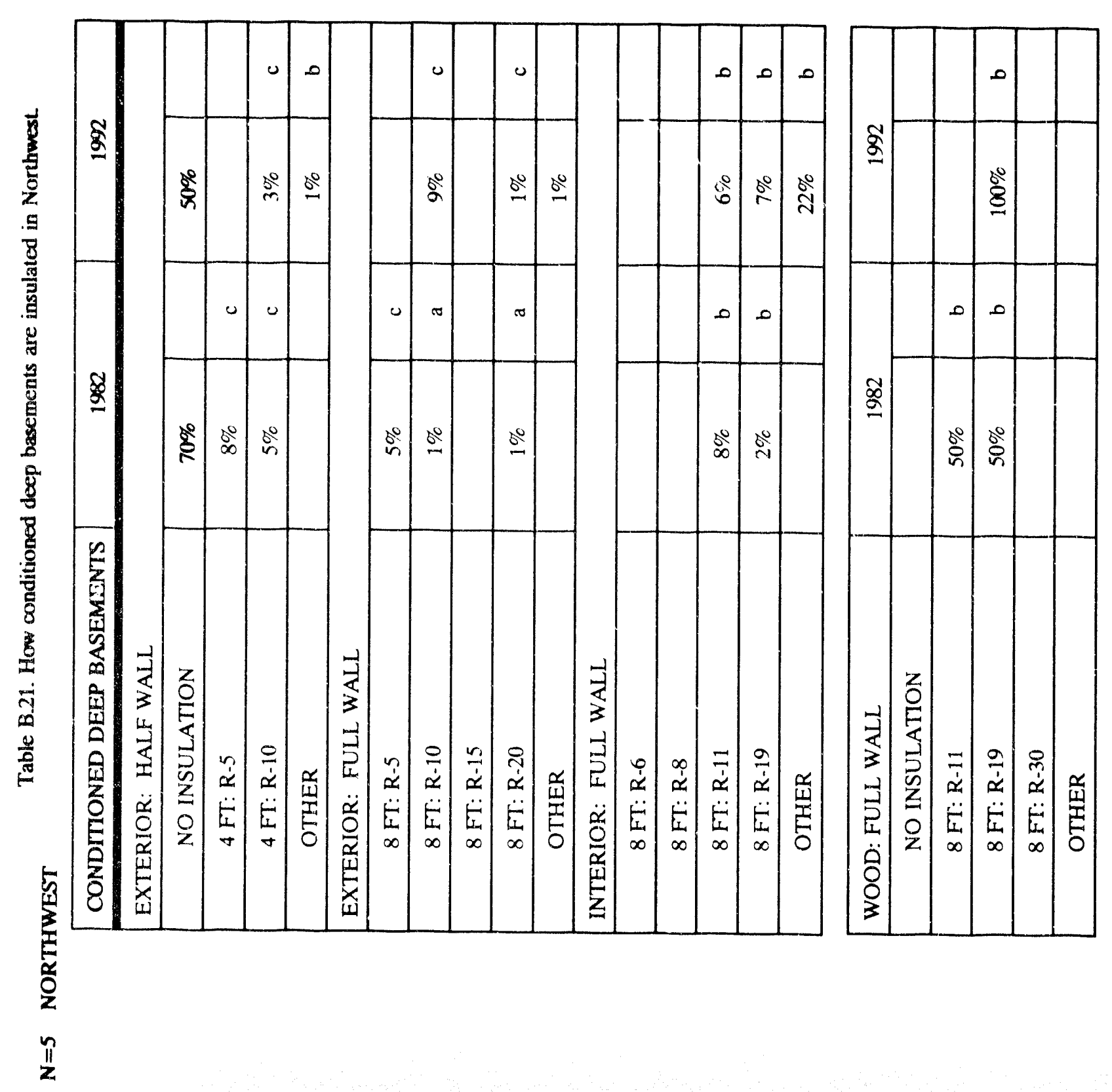




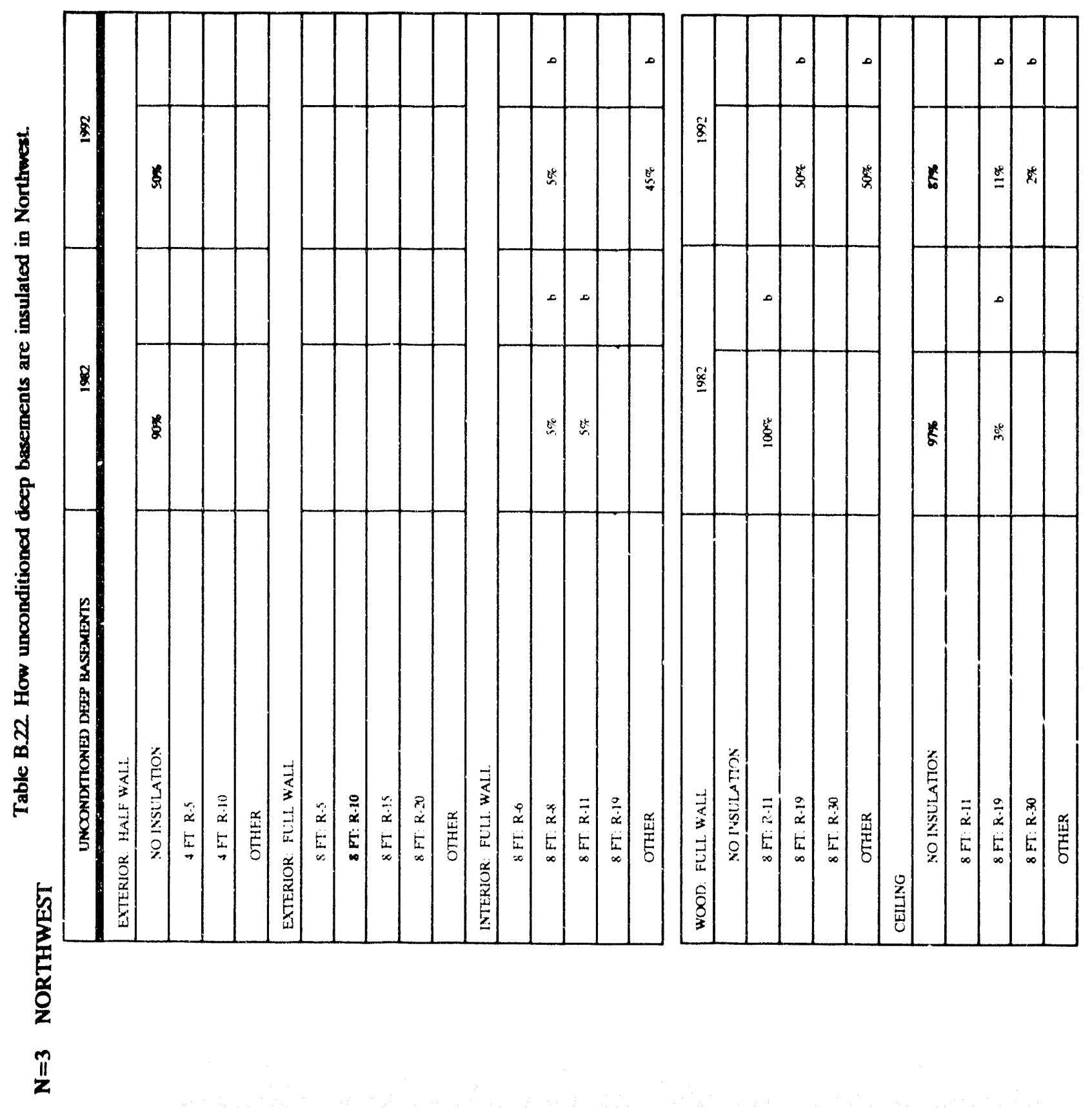




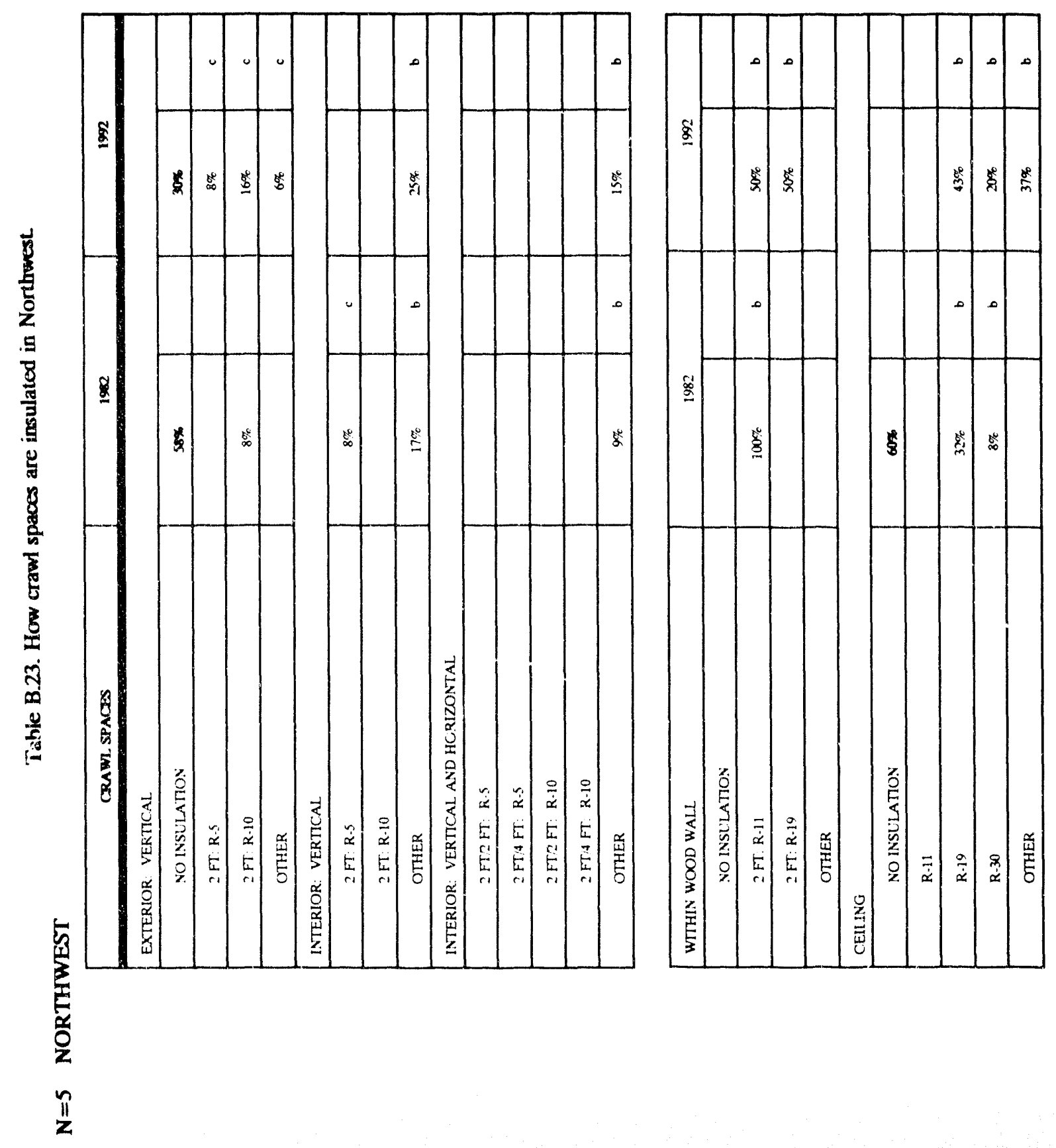




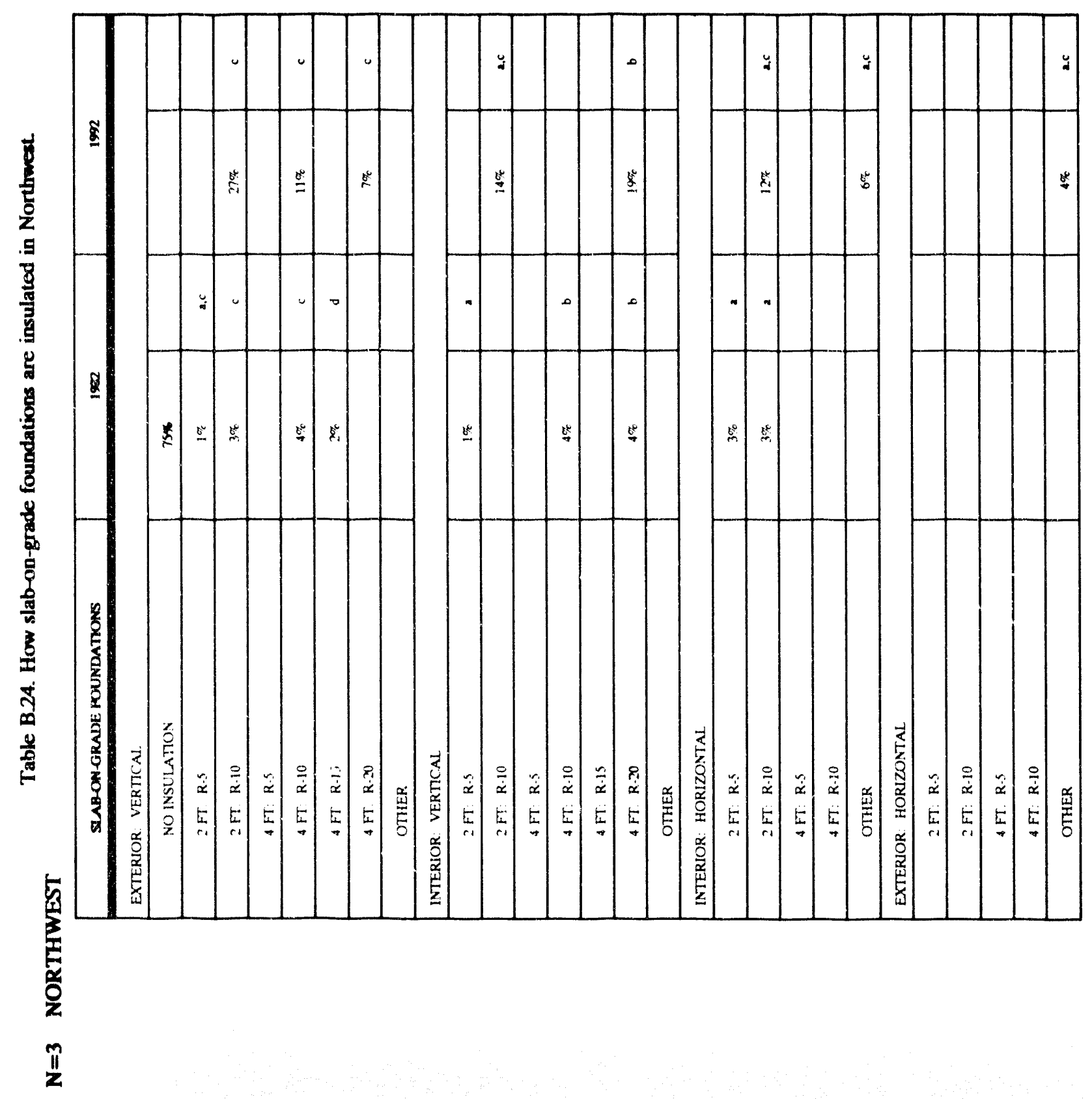



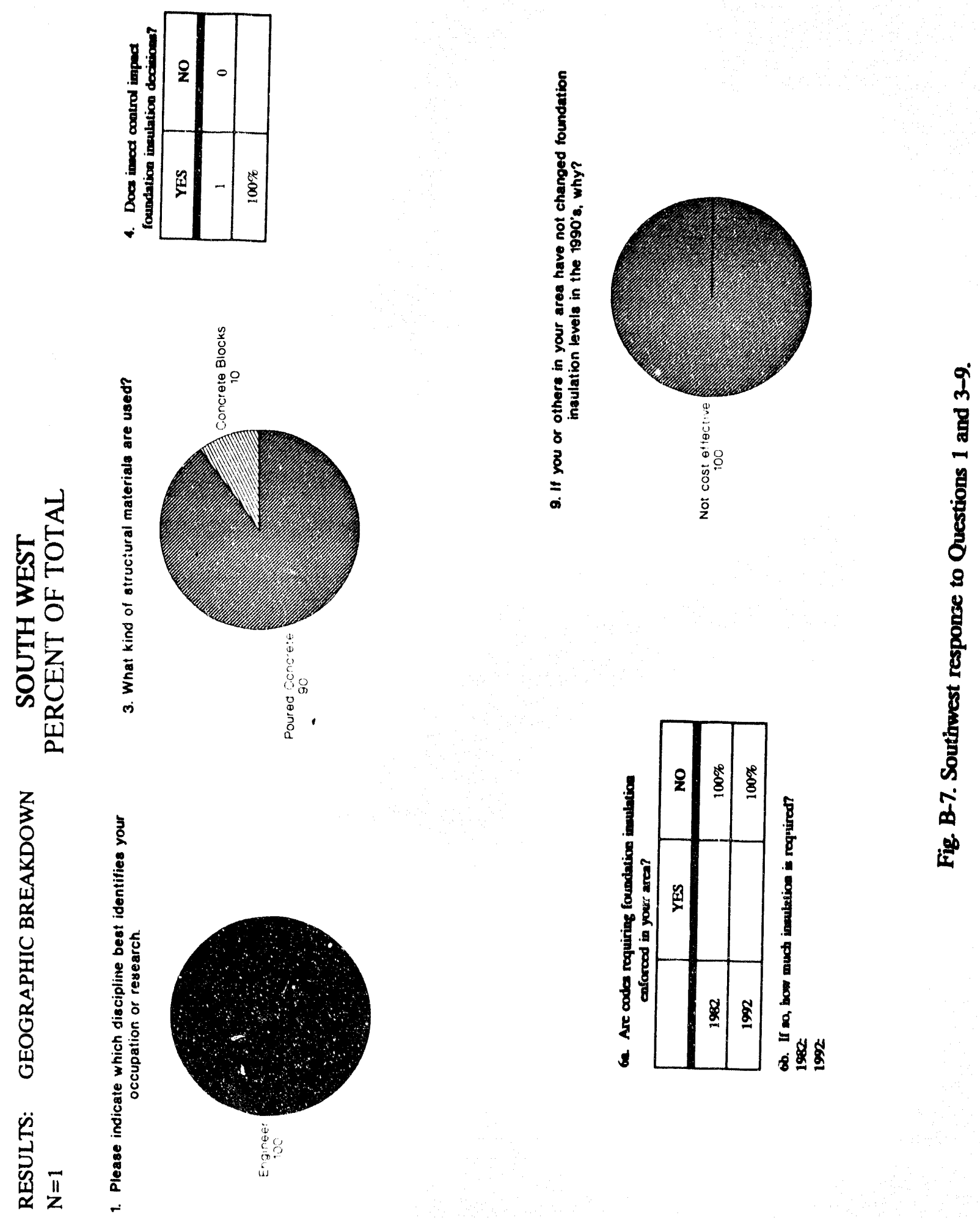


\section{INTERNAL DISTRIBUTION}

1-10. J. E. Christian

11. G. E. Courville

12. M. A. Broders

13. R. B. Shelton

14-23. C. L. Brown

24. M. A. Brown

25. R. S. Carlsmith

26. A. O. Desjarlais

27. P. D. Fairchild

28. S. K. Fischer

29. M. B. Gettings
30. J. O. Kolb

31. T. G. Kollie

32. M. A. Kuliasha

33. P. M. Love

34. W. R. Mixon

35. ORNL Patent Office

36. Central Research Library

37. Document Reference Section

38. Laboratory Records - RC

39-41. Laboratory Records

\section{EXTERNAL DISTRIBUTION}

42. Robert L. Alumbaugh, Naval Civil Engineering Laboratory, Port Hueneme, CA 93043-5003

43. James L. Anderson, Foam Enterprises, Inc., 13630 Watertower Circle, Minneapolis, MN 55441

44. Aaron Applegate, P.O. Box 292, Okemos, MI 48805

45. Erv Bales, University Heights, New Jersey Institute of Technology, Newark, NJ 07102

46. Roger Barker, Georgia Pacific Corp., 133 Peachtree St., N.E., 20th Floor, Atlanta, GA 30303

47. Mark Bomberg, National Research Council Canada, Ottawa, Ontario, Canada K1A 0R6

48. J. Boone, Wichita Insulation, 12727 E. Kellogg; Wichita, KS 67207

49. Jean Boulin, Dept. of Energy, CE-43, FORSTL, 1000 Independence Ave., S.W., Washington, D.C. 20585

50. Maribeth S. Bradfield, NCMA, 2302 Horse Pen Road, Herndon, VA 22071-3406

51. Stephen G. Braun, North American Insulation Mfgrs. Assoc., Suite 310, 44 Canal Center Plaza, Alexandria, VA 22314-1592

52. Jeffrey R. Brisley, Knauf Fiberglass, 240 Elizabeth Street, Shelbyville, IN 46176

53. Donald E. Brotherson, One E. Saint Mary's Road, Champaign, IL 61820

54. Bruce G. Buchanan, Computer Science Dept., University of Pittsburgh, 206 Mineral Industrics Building, Pittsburgh, PA 15260

55. CAREIRS Librarian, 2000 N. 15th Street, Suite 407, Arlington, VA 22201-2627

56. Dave Crouse, Stepan, 22 W. Frontage Road, Northfield, IL 60093

57. Jack Davis, Florida Power Corp., P.O. Box 14042, St. Petersburg, FL 33733

58. Clayton DeKorne, Journal of Light Construction, RR 2, Box 146, Richmond, VT 05477

59. Rene M. Dupuis, Structural Research, Inc., 3213 Laura Lane, Middleton, WI 53562 
60. W. M. Edmunds, Owens-Corning Fiberglas, 2790 Columbus Road, Granville, OH 43023

61. Helen English, Passive Solar Industries Council, 1511 K Street, N.W., Suite 600), Washington, D.C. $20(0) 5$

62. P. R. Fisette, Room 126, Holdsworth Hall, University of Massachusetts, Amherst, MA 01003

63. William Freeborne, U.S. Dept. of Housing and Urban Development, 451 Seventh St., S.W., Room 8138, Washington, D.C. 20410

64. Warren R. French, French Engineering, Inc., 15531 Kuykendahl, Suite 275, Houston, TX 77(09)

65. Charles Gilbo, Journal of Thermal Insulation, 1820 Westcott Drive, Lancaster, PA 1760)3-2371

66. Pat Gleason, Idaho Dept. of Water kesources, 1301 N. Orchard St., Boise, ID 83706

67. Leon R. Glicksman, M.I.T., 4-209, 77 Massachusetts Avenue, Cambridge, MA 02139

68. William P. Goss, Mechanical Engineering Dept., University of Massachusetts, Amherst, MA 01003

69. Thomas Greeley, BASF, 100 Cherry Hill Road, Parsippany, NJ 07054

70. Tim Grether, Owens/Corning Fiberglas, Fiberglas Tower, Toledo, OH 43659

71. Jack Gusler, G.W.S., 2706 Wyndham Lane, Orlando, FL 32808

72. Joseph R. Hagan, Center for Applied Enginecring, 10301 Ninth Street, North, St. Petersburg, FL 33716

73. David A. Harris, National Institute of Building Sciences, 1201 L Street, N.W., Suite 400, Washington, D.C. 20005

74. Tom Harris, BASF Canada, Inc., 345 Carlingview Drive, Rexdale, Ontario, Canada M9W 6N9

75-77. Donna Hawkins, Dept. of Energy, CE-40, FORSTL, 1000 Independence Ave., S.W., Washington, D.C. 20585

78. Phil Hendrickson, Dow Chemical, USA, P.O. Box 515, Granville, OH 43023

79. Bion Howard, 14513 Kent Drive, Upper Marlboro, MD 20772

80. Helen M. Ingram, Udall Center for Studies in Public Policy, The University of Arizona, 803/811 East First Street, Tucson, AZ 85719

81. Michael Ivanovich, P.O. Box 2218, Boulder, CO 80306

82. Richard Karney, Dept. of Energy, CE-421, FORSTL, 1000 Independence Ave., S.W., Washington, D.C. 20585

83. Mark Kelley, Building Science Enginecring, 85 Depot Road, Harvard, MA 01451

84. Philip Knight, Lockwood Green, Oak Ridge Turnpike, Oak Ridge, TN 37830

85. Richard Kramer, National Pest Control Assoc., 8100 Oak Street, Dunn Loring, VA 22027

86. Walter Kroner, Rensselaer Polytechnic Institute, Architectural Research, Greene 103, 1108 th Street, Troy, NY 12180

87. Gene Leger, Leger Designs, 256 Middle Branch Road, New Boston, NH 03070

88. John J. Leimanis, Dept. of State, FBO/BDE/FSB, P.O. Box 12248, Rosslyn Station, Arlington, VA 22219

89. Fran Lichtenberg, The Society of the Plastics Industry, 355 Lexington Avenue, New York, NY 10017

90. Calvin D. MacCracken, Calmac Manufacturing Corporation, 101 West Sheffield Avenue, P.O. Box 710, Englewood, NJ 07631

91. Robert F. Martin, Roof Maintenance Systems, P.O. Box 67, Farmingoak, NJ 07727

92. William F. Martin, Roof Design Works, Inc., 516 Renford Drive, Knoxville, TN 37919

93. Jerry Marx, Safety \& Buildings Division, P.O. Box 7964, Madison, WI 53707 
94. Merle F. McBride, Owens-Corning Fiberglas, 2790 Columbus Road, Granville, OH 43023-1200

95. David McCaa, Certainteed Corporation, 1400 Union Mecting Road, Blue Bell, PA 19422-0761

96. Duvon McGuire, Regal Industries, Inc., Route 1, Box 46, Crothersville, IN 47229

97. R. Gerry Miller, Center for Applied Enginecring, Inc., 10301 9th Street, N., St. Petersburg, FL 33716

98. Pat Mulroy, Blackgold, Inc., 4502 Burlingame Road, Topeka, KS 66609

99. NCAT Library, National Center for Appropriate Technology, P.O. Box 3838, Butte, MT 59702

100. Bruce D. Nelson, Minn. Dept. of Public Service, 150 E. Kellogg Blvd, \#790, St. Paul, MN 55101

101. Ned Nisson, Energy Design Update, P.O. Box 1709, A r.. „nia Station, New York, NY 10023

102. David G. Oher, 25 Wiggins Avenue, Bedford, MA 01730

103. Larry Plocher, Central Insulation, 9835 Highway 284 , Waconia, MN 55387

104. Frank Povvell, 12218 Cattail Lane, Jacksonville, FL 32223

105. Donald Prowler, 2302 Locust Street, Philadelphia, PA 19103

106. Paul Remmele, Morton Builàings, Inc., P.O. Box 399, Morton, IL 61550

107. A. Sterett Robertson, DowElanco, P.O. Box 681428, Indianapolis, IN 46268-1189

108. David Roodvoets, Dow Chemical U.S.A., 3825 Columbus Road, S.W., F Bldg., Granville, OH 43023

109. William Rose, Small Homes Council, 1 East St. Mary's Road, Champaign, IL 61820

110. W. J. Rossiter, NIST, Bldg. 226, Rm. B348, Gaithersburg, MD 20899

111. Russell Rudy, Kansas Weatherization Assistance, Dept. of Commerce, 400 S.W. 8th Street, Suite 500, Topeka, KS 66603

112. Thomas Sayre, Sizemore/Floyd Architects, 600 W. Peachtree Strect, Suite 1000, Atlanta, GA 30308

113. Peter Scofield, Department of Energy, CE-421, FORSTL, 1000 Independence Ave., S.W., Washington, D.C. 20585

114. Richard Seifert, University of Alaska, Cooperative Extension Service, Arctic Health Research 104, Fairbanks, AK 99775-5200

115. Stephen Selkowitz, Windows and Daylighting Group, Lawrence Berkeley Laboratory, One Cyclotron Road, Building 90-3111, Berkeley, CA 94720

116. Morton Sherman, Consultant, 6723 14th Avenue, North, St. Petersburg, FL 337105405

117. Jacqueline B. Shrago, Office of Technology Transfer, 405 Kirkland Hall, Vanderbilt University, Nashville, TN 37240

118. S. E. Smith, Physical Sciences Group, 48 Chester Street, Somerville, MA 02144

119. Lawrence G. Spielvogel, Lawrence G. Spielvogel, Inc., 203 Hughes Road, King of Prussia, PA 19406-3785

120. Richard Spray, Agricultural Enginecring, 210 McAdams Hall, Clemson University, Clemson, SC 29634-0357

121. Bruce Spurlock, Southern Services, 64 Perimeter Center, Atlanta, GA 30346

122. Raymond L. Sterling, Underground Space Center, 500 Pillsbury Drive, S.E., Minneapolis, MN 55455

123. Ed Story, Insul-Tray, Inc., E. 1881 Crestview Drive, Shelton, WA 98584-9082

124. William R. Strzepek, Dow U.S.A., P.O. Box 515, Granville, OH 43023

125. Anton TenWolde, U.S. Dept. of Agriculture, Forest Products Laboratory, One Gifford Pinchot Drive, Madison, WI 53705-2398 
126. Timothy Tong, Dept. of Mechanical \& Aerospace Eng., Arizona State University, Tempe, AZ 85287

127. George Tsongas, Mechanical Engineering Dept., Portland State University, P.O. Box 751, Portland, OR 97207

128. Adrian Tuluca, Steven Winter Associates, Inc., 50 Washington Sireet, Norwalk, CT 06854

129. R. P. Tye, 292 Jerusalem Road, Cohasset, MA 02025

130. Carl R. Vander Linden, Vander Linden \& Assoc., 5 Brassie Way, Littleton, CO 80123

131. Martha G. Van Geem, Construction Technology Laboratory, 5420 Old Orchard Road, Skokie, IL 60077

132. Jack Verschoor, 179 Gail Avenue, Bailey, CO 80421

133-142.Melissa Voss, Rural Route 3, Box 122, Macomb, IL 61455

143. Jack R. Warner, 6427 Forest Road, Cheverly, MD 20785

144. David J. Williams, Dow Chemical, P.O. Box 515, Granville, OH 43023

145. Martin Williams, Department of Economics, Northern Illin'is University, DeKalb, IL 60115

146. Andrew Wynn, Central Maine Power Company, Edison Drive, Augusta, ME 04336

147. Office of the Assistant Manager for Energy Research and Development, DOE-ORO, P.O. Box 2001, Oak Ridge, TN 37831-8600

148-187.BTESM Library, Oak Ridge National Laboratory, P.O. Box 2008, Bldg. 3114, Oak Ridge, TN 37831-6070

188-197.OSTI, U.S. Dept. of Energy, P.O. Box 62, Oak Ridge, TN 37831 

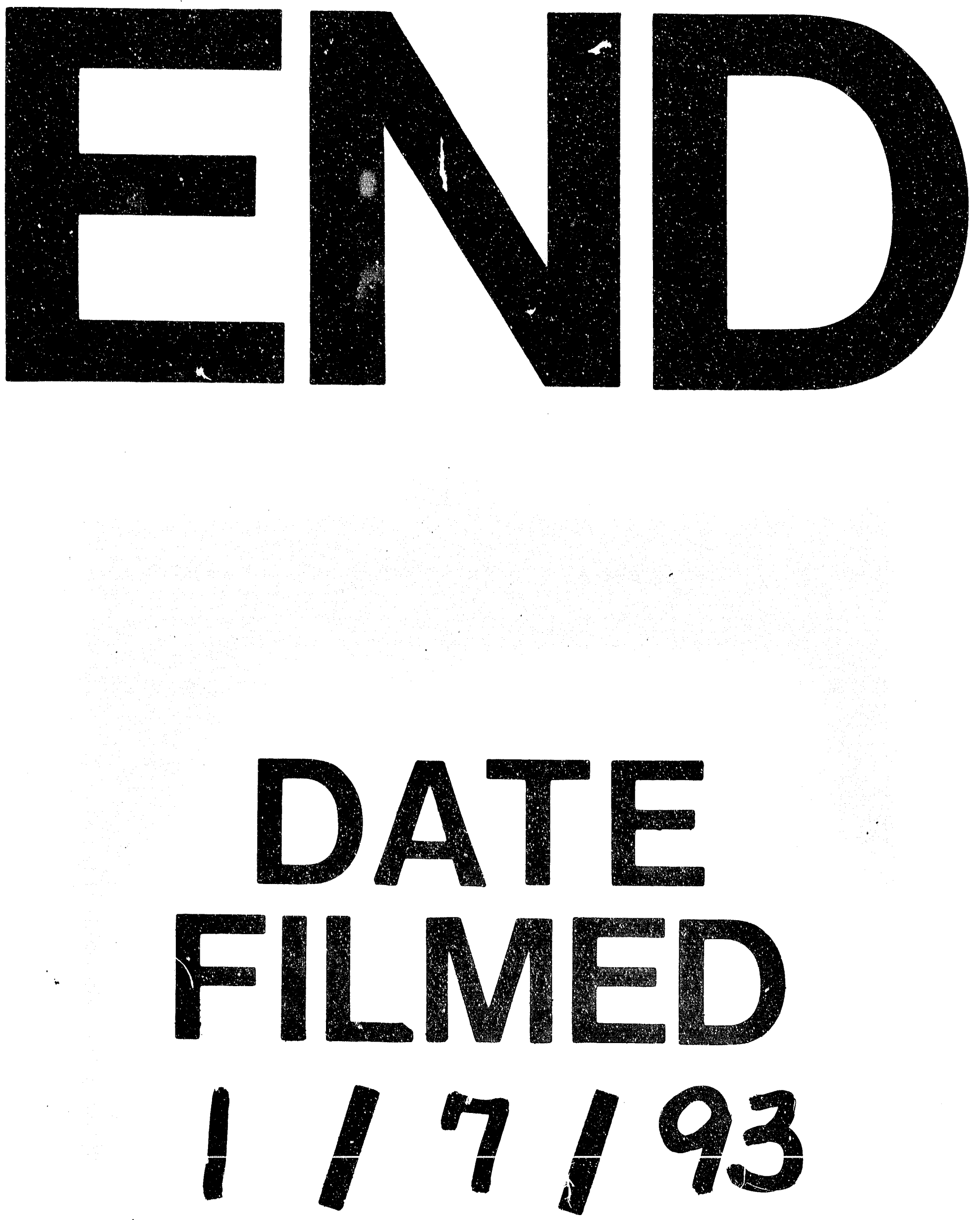
